\title{
Zambia: Request for Three-Year Arrangement Under the Poverty Reduction and Growth Facility—Staff Report; Staff Statement; Press Release; and Statement by the Executive Director for Zambia
}

In the context of the request for a three-year arrangement for Zambia under the Poverty Reduction and Growth Facility, the following documents have been released and are included in this package:

- $\quad$ the staff report for the request for three-year arrangement under the Poverty Reduction and Growth Facility, prepared by a staff team of the IMF, following discussions that ended on April 26, 2004, with the officials of Zambia on economic developments and policies. Based on information available at the time of these discussions, the staff report was completed on May 28, 2004. The views expressed in the staff report are those of the staff team and do not necessarily reflect the views of the Executive Board of the IMF.

- $\quad$ a staff statement of June 14, 2004 updating information on recent developments.

- $\quad$ a Press Release summarizing the views of the Executive Board as expressed during its June 14, 2004 discussion of the staff report that completed the request.

- a statement by the Executive Director for Zambia.

The documents listed below have been or will be separately released.

Letter of Intent sent to the IMF by the authorities of Zambia* Memorandum of Economic and Financial Policies by the authorities of Zambia* Poverty Reduction Strategy Paper Progress Report Poverty Reduction Strategy Paper Progress Report—Joint Staff Assessment Technical Memorandum of Understanding*

*May also be included in Staff Report

The policy of publication of staff reports and other documents allows for the deletion of market-sensitive information.

To assist the IMF in evaluating the publication policy, reader comments are invited and may be sent by e-mail to publicationpolicy@imf.org.

Copies of this report are available to the public from

International Monetary Fund • Publication Services

$70019^{\text {th }}$ Street, N.W. • Washington, D.C. 20431

Telephone: (202) 623-7430 • Telefax: (202) 623-7201

E-mail: publications@imf.org • Internet: http://www.imf.org

Price: $\$ 15.00$ a copy

\section{International Monetary Fund}

Washington, D.C. 



\title{
INTERNATIONAL MONETARY FUND
}

\author{
ZAMBIA \\ Request for a Three-Year Arrangement \\ Under The Poverty Reduction and Growth Facility
}

\author{
Prepared by the African Department \\ (In consultation with other departments) \\ Approved by Anupam Basu and G. Russell Kincaid
}

May 28, 2004

- Discussions on a new Poverty Reduction and Growth Facility (PRGF) arrangement were held in Zambia from April 13 to 23, 2004 and concluded in Washington in late April. The staff team met with Mr. Magande, Minister of Finance and National Planning, Mr. Kalyalya, Deputy Governor of the Bank of Zambia (BoZ), other senior officials, representatives of the private sector and civil society, and members of the diplomatic and donor community.

- The staff team comprised Mr. Andrews (head), Mr. Thugge, Mr. Fassina, Mr. Bagattini (all AFR), Mr. Staines (PDR), Mr. Baldini (FAD), and Mr. Kakoza (Resident Representative). The mission worked closely with World Bank staff.

- Zambia's last PRGF arrangement expired in March 2003. The Board concluded the 2003 Article IV consultation on April 7, 2004. After consideration of a new three-year PRGF arrangement was precluded by a large projected budget overrun, the authorities requested a staff-monitored program (SMP) covering the period July-December 2003. Performance under the SMP was not satisfactory, and the SMP was extended to June 2004. Through end March, performance under the SMP was strong. The staff will report on performance through April and May (based on preliminary data) at the time of the board meeting.

- Zambia is requesting a three-year arrangement under the PRGF in an amount of SDR 220.095 million (45 percent of quota) to support the program, in the attached letter of intent and memorandum of economic and financial policies (MEFP).

- The government has also prepared a progress report on the implementation of its poverty reduction strategy paper (PRSP). A joint staff assessment (JSA) concluded that the strategy continues to provide a credible framework for Fund and World Bank concessional assistance, and recommends the Executive Boards of the World Bank and the Fund support this conclusion.

- Since his election in 2001, President Mwanawasa has increased his slim majority in parliament by appointing opposition members to cabinet and winning by-elections. The government's anticorruption campaign has resulted in former President Chiluba facing court charges of corruption and misuse of public resources. 


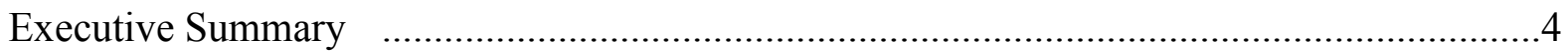

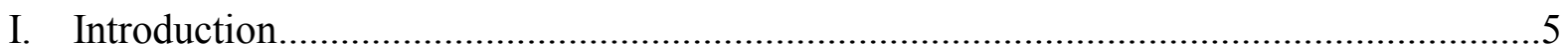

II. Recent Economic Developments and Performance under the Extended Staff-Monitored

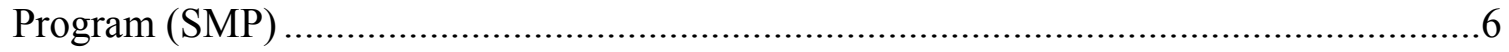

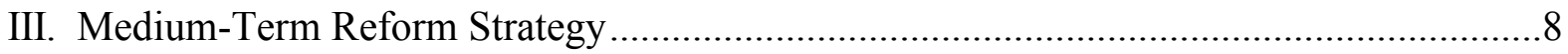

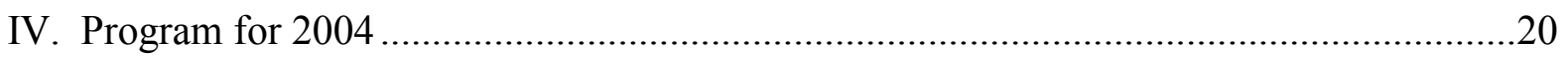

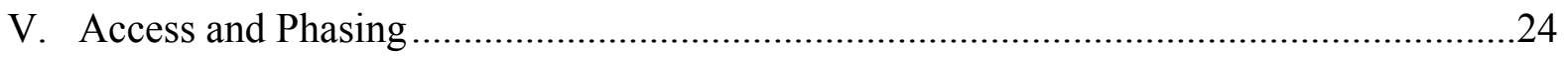

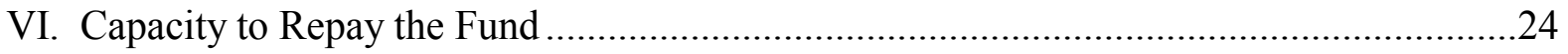

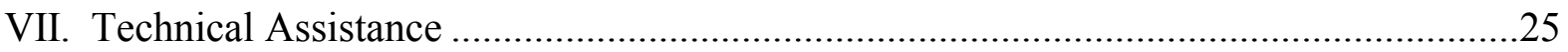

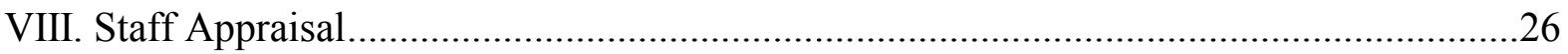

Figures

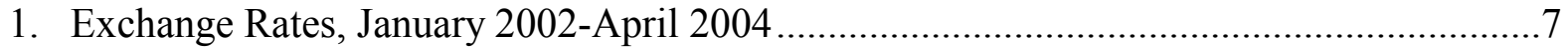

2. Real GDP Growth, 1990-2007 (In annual percent change) ............................................10

3. Inflation, January 1996-December 2004 (Twelve-month percentage change) ..................20

Boxes

1. Commercialization of Zambia Energy Supply Company ……….......................................

2. Prospects for Reaching the Millennium Development Goals ............................................11

3. Poverty and Social Impact Analysis (PSIA) .................................................................13

4. Public Expenditure Management and Financial Accountability Program ..........................16

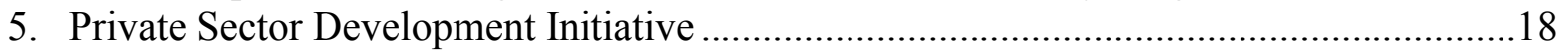

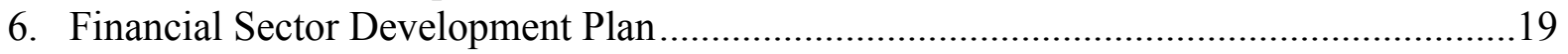

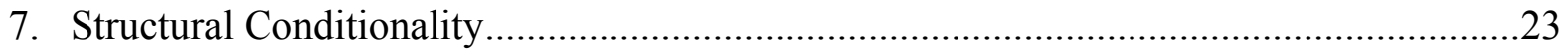

Tables

1. Selected Economic and Financial Indicators, 2002-07 ...........................................29

2. Status of Key Reform Objectives For Reaching the Floating Completion Point Under the Enhanced HIPC Initiative ………………………........30

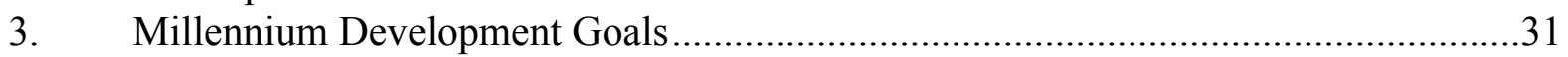

4. Central Government Overall Operations, 2002-07 (In billions of kwacha)..................33

5. Central Government Overall Operations, 2002-07 (In percent of GDP) ......................34

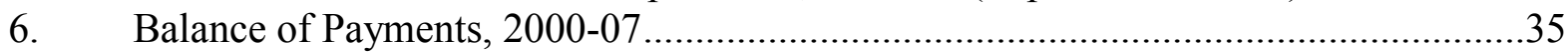

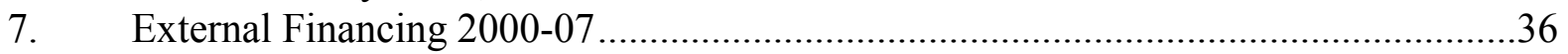

8. Assets and Liabilities of the Bank of Zambia, 2000-04 ..............................................3 


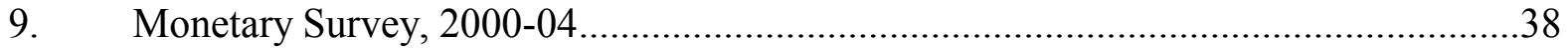

10. Schedule of Disbursements Under the Proposed PRGF Arrangement, 2004-07 ..........39

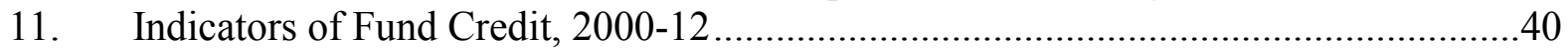

Appendices

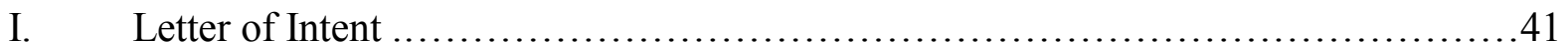

Memorandum of Economic and Financial Policies for the Period

July 2004 to June 2007 .......................................................................................

II. Technical Memorandum of Understanding for the

Poverty Reduction and Growth Facility (PRGF) Arrangement ...............................60

III. Relations with the Fund .......................................................................................

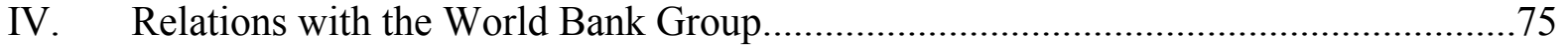

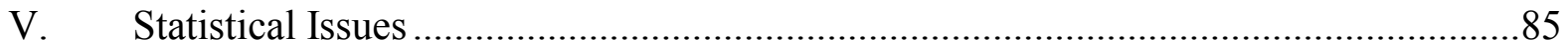

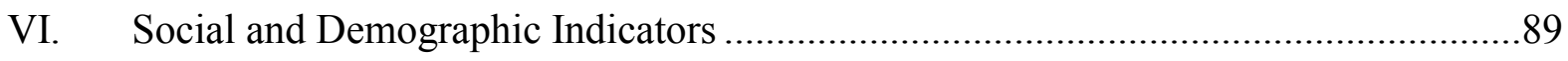




\section{Executive Summary}

\section{Recent Developments}

- Growth in 2003 is now estimated at 5.1 percent, and the economy is expected to grow by 3.5 percent in 2004, marking the fifth consecutive year of economic expansion. Despite the effects of high oil prices, inflation is projected to remain below 20 percent.

- Through end-March, most of the key quantitative benchmarks and six of the eight structural benchmarks under the staff-monitored program (SMP) were observed. Progress was also made in meeting the triggers for reaching the Heavily Indebted Poor Countries (HIPC) Initiative completion point.

- The government prepared the first annual progress report on the implementation of the poverty reduction strategy paper (PRSP). The IMF-World Bank joint staff assessment concluded that the strategy continues to provide a credible framework for financial assistance but satisfactory implementation has yet to be established.

\section{Medium-Term Outlook and Program}

- Zambia's economy remains fragile. The government's medium-term strategy, articulated in the PRSP and the progress report, aims at increasing diversification and reinforcing poverty-reducing interventions. It targets real GDP growth of at least 5 percent, an inflation rate in single digits, and a strengthening of the international reserve position.

- In support of this strategy, the authorities are committed to implementing reforms to strengthen public expenditure management, improve the efficiency of government operations, develop the financial system, remove obstacles to private sector development, and improve governance.

\section{Macroeconomic Program for 2004}

- The Poverty Reduction and Growth Facility (PRGF)-supported program is based on a strong fiscal adjustment envisaged in the 2004 budget and a modest growth of reserve money. A sharp decline in domestic financing of the budget relies on expenditure restraint. Despite the adjustment, the government targets a significant increase in poverty-reducing spending.

- The government's agenda on structural reforms focuses on approving and executing the initial steps of a comprehensive plan to improve public expenditure management; piloting an Integrated Financial Management Information System (IFMIS); introducing a system to improve payroll management; completing a plan for rightsizing the civil service; finalizing a financial sector development plan in line with Financial Sector Assessment Program (FSAP) recommendations; and resolving three state-owned nonbank financial institutions.

- The proposed access of 45 percent of quota, which would be highly frontloaded, balances the need to support Zambia's efforts to achieve sustained growth and the risks to the Fund. Three-quarters of the access would be available in 2004 to safeguard Zambia's reserve position when debt-service payments stemming from the settlement of arrears in 1995 are high. Satisfactory performance under the PRGF through December 2004 would pave the way for Zambia to reach the HIPC Initiative completion point in the first half of 2005 . 


\section{INTRODUCTION}

1. In the attached letter of intent, Zambia's Minister of Finance and National Planning requests a three-year arrangement under the Poverty Reduction and Growth Facility (PRGF) in an amount of SDR 220.095 million (45 percent of quota). The new arrangement would help Zambia meet its challenges in macroeconomic management and structural reform as set out in the attached memorandum of economic and financial policies (MEFP). Access under the arrangement is below the average for third time users, in view of Zambia's high outstanding use of PRGF resources and track record. Reflecting satisfactory performance under the staff-monitored program (SMP) during 2004 and to help Zambia meet its obligations to the Fund, while maintaining adequate reserve levels before the Heavily Indebted Poor Countries (HIPC) Initiative completion point can be reached in 2005, this access is also highly frontloaded.

2. The government has also prepared a progress report on the implementation of its poverty reduction strategy paper (PRSP). ${ }^{1}$ A joint staff assessment (JSA) concluded that satisfactory implementation of the PRSP still needs to be established, but that the strategy continues to provide a credible framework for Fund and World Bank concessional assistance. $^{2}$

3. In concluding the 2003 Article IV consultation, Directors welcomed Zambia's improved economic performance but noted macroeconomic stability had yet to be firmly entrenched. Directors stressed the need for determined implementation of prudent macroeconomic policies and structural reforms to boost economic growth, reduce poverty, and achieve the Millennium Development Goals (MDGs). Fiscal adjustment was called for to achieve fiscal sustainability, increase spending on poverty reduction, and free up resources to support private investment. They urged that the wage bill should be held to 8 percent of GDP to provide room for priority expenditures. Directors welcomed the generally satisfactory performance so far under the extended SMP for 2004 and stressed that continued good implementation will be crucial for Zambia to move as soon as possible to a PRGF arrangement. Such an arrangement would pave the way for Zambia to reach the completion point under the enhanced HIPC Initiative and obtain increased external assistance.

4. Directors also supported the conclusions of the ex post Assessment (EPA) of Zambia's performance under past Fund-supported programs. The assessment pointed to the need for fiscal policy to bear a greater burden of adjustment to facilitate a sustainable reduction in real interest rates and support private domestic investment. Development and implementation of public sector reforms to support tight control of the wage bill and

\footnotetext{
${ }^{1}$ IMF Country Report No. 04/181.

2 IMF Country Report No. 04/179.
} 
improvements in public expenditure management were seen as crucial to fiscal consolidation and a reorientation of spending to poverty reduction. Accelerating growth would also require removal of obstacles to private sector development. Financial sector reforms should follow through on the conclusions of the Financial Sector Assessment Program (FSAP), including resolving government-owned nonbank financial institutions (NBFIs) and improving rural banking services. Avoidance of ad hoc spending decisions and strict enforcement of budgetary procedures were seen as key tests of ownership. The assessment also noted the need to strengthen the monitoring of program implementation and improve policy coordination within government.

\section{RECENT ECONOMIC DEVELOPMENTS AND PERFORMANCE UNDER THE EXTENDED StAFF-Monitored Program (SMP)}

\section{As described in the authorities' MEFP, Zambia's growth performance has} continued to strengthen. In 2003, growth reached 5.1 percent, marking the fourth consecutive year of economic expansion and the longest period of sustained growth in more than two decades. At the same time, inflation declined to 17 percent at the end of 2003, the lowest level in over 20 years (Table 1).

6. The favorable outcomes for growth and inflation in 2003 were, however, aided by exogenous developments that helped to mask the impact of serious policy slippages. Large unbudgeted expenditures related to security and payment of retrenchment benefits and wage arrears to workers in the Luanshya Mine and shortfalls in external assistance, partly due to the delay in proceeding with a new PRGF arrangement, resulted in domestic borrowing in 2003 of 5 percent of GDP, compared with the 2 percent of GDP in 2002 (Appendix I, para. 4). At the same time, spending on poverty-reducing programs fell short of the budgeted levels.

7. The authorities' budget for 2004, approved at the beginning of April, is geared to averting a further upward spiral in domestic debt and interest costs. In the first three months of 2004, fiscal performance improved significantly. Revenues through end-March were in line with targets established under the extended SMP. The ceiling on domestic financing was met by a comfortable margin, and all expenditure categories were at or below their programmed levels.

8. In 2003, the initially tight stance of monetary policy was eased to accommodate government's higher recourse to bank financing. The growth in broad money ended the year at 23 percent, which was higher than targeted but lower than in 2002 (32 percent). In October 2003, the Bank of Zambia (BoZ) lowered cash legal reserve requirements from 17.5 percent to 14 percent. The resulting excess liquidity in the banking system pushed treasury bill interest rates down to around 20 percent at end-December 2003 from above 30 percent. Although broad money growth was below the program target through March 2004, treasury bill rates have continued to decline, dropping to below 8 percent, which is 
substantially below inflation of 17.8 percent in the 12 months to April. Recently, the BoZ has acted to mop up liquidity (see para. 30).

\section{External developments in 2003 were}

favorable. Bolstered by higher copper prices and continued growth in nontraditional exports, total exports rose by an estimated 23 percent, compared with a 13 percent increase in total imports. As a result the external current account deficit, including grants, narrowed by almost 1 percent of GDP to 5.6 percent of GDP in 2003. These favorable developments have persisted in 2004, which has helped the kwacha remain broadly stable against the U.S. dollar, and in real effective terms (Figure 1).

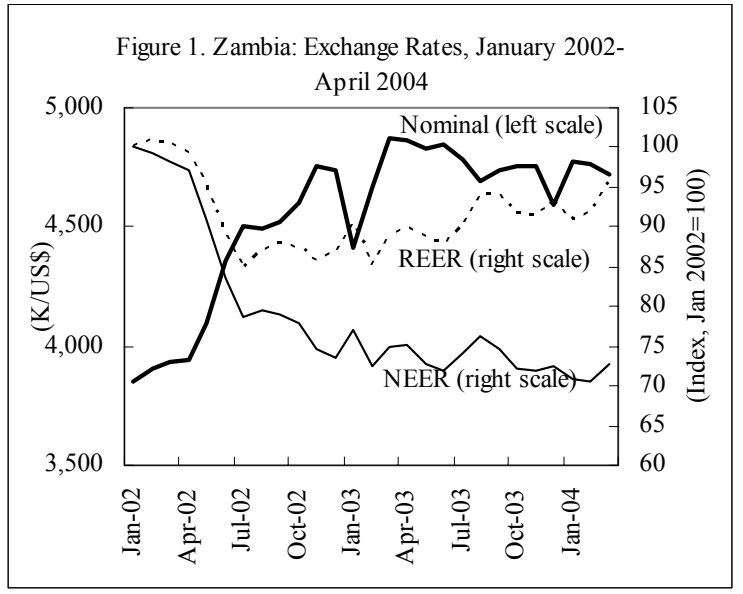

10. Eight of the nine quantitative benchmarks at end-March were met (Appendix I, para. 1 and Table 3). Wage arrears of $K 16$ billion ( 3 percent of the wage bill) in the first quarter, which were mainly due to a short delay in the payment of housing allowances, resulted in the nonobservance of the corresponding benchmark However, the ceiling on the wage bill, and all other targets in the program, would still have been met if wage arrears had not been incurred. Government revenues in the first quarter were as programmed. However, since capital spending started the year slowly, pending approval of the budget, the key ceilings on net domestic financing and net domestic assets were met by wide margins. The Ministry of Finance and National Planning (MoFNP), in close collaboration with line ministries, has established quarterly ceilings for expenditure commitments to gradually return to the expenditure profile envisaged under the program. Higher BoZ purchases of foreign exchange raised gross international reserves (US\$177 million) above the adjusted program floor of US\$171 million.

\section{Six of the eight structural benchmarks through end-April were observed}

(Appendix I, Table 2). The two benchmarks that were missed were: the preparation of an action plan for the insolvent NBFIs, as the Government sought additional technical assistance; and the signing of a contract for the procurement of hardware and software for an Integrated Financial Management and Information System (IFMIS), which is now expected to take place in June 2004. On other structural reforms, discussions with the first preferred bidder for the partial sale of Zambia National Commercial Bank (ZNCB) are continuing; however, in order to expedite the sale, the Zambia Privatization Agency (ZPA) initiated parallel discussions with the second preferred bidder. The government completed the sale of the Luanshya mine, formerly owned by the Roan Antelope Mining Company of Zambia (RAMCOZ), in early 2004, and has made substantial progress in seeking a new strategic equity investor for the Konkola Copper Mines (KCM). 
12. The government made progress toward implementing the triggers for reaching the floating completion point under the HIPC Initiative (Table 2). The macroeconomic environment has improved, as evidenced by the satisfactory performance under the extended SMP. Measures have been implemented in the areas of health and education, and in the privatization of ZNCB and the commercialization of the Zambia Energy Supply Company (ZESCO). The government no longer intends to privatize ZESCO-a HIPC Initiative completion point trigger - and has adopted a commercialization strategy to achieve the same objectives (Box 1). Building on the experience in preparing the 2004-06 medium-term expenditure framework (MTEF), the Ministry of Finance and National Planning is working to prepare the MTEF for 2005-07. The PRSP annual progress report was finalized in March 2004 and has been issued to the Boards of the Fund and the World Bank.

\section{Following the difficulties that arose in 2003, the Zambian authorities have} emphasized the importance of reaching the HIPC Initiative completion point without delay. In this vein, the PRSP progress report assumes that the completion point would be reached at the end of 2004. However, the staff considers that, with a PRGF arrangement starting in June, it will not be possible to reach the completion point in 2004. Completion of the second review under the PRGF, based on performance through end-December 2004, would establish the minimum track record of six months under a PRGF arrangement required to reach the completion point. In addition, the government's second annual PRSP progress report, which would cover the year to June 2004, would need to demonstrate a year's satisfactory implementation of the PRSP to reach the completion point.

\section{MEDIUM-TERM REFORM STRATEGY}

\section{The government's PRSP, which was prepared in 2002, set out a medium-term} strategy for growth and poverty reduction. This strategy, which focused on promoting growth through diversification and improving the quality of public services, was reaffirmed in the government's first annual progress report. As discussed in the first progress report on the PRSP and the accompanying JSA, the macroeconomic framework underlying the PRSP has been revised to take account of developments during 2003. The framework now envisages fiscal consolidation to prevent a further escalation of domestic debt and interest payments that would jeopardize macroeconomic stability and sharply constrain spending on poverty reduction. The main elements of this strategy, including sources of growth, policies to support private sector development, the need for fiscal consolidation, and a reorientation of general spending, were also discussed in the staff report for the Article IV consultation. ${ }^{3}$

\footnotetext{
${ }^{3}$ Zambia-Staff Report for the 2003 Article IV Consultation (Country Report No. 04/214).
} 


\section{Box 1. Commercialization of Zambia Energy Supply Company (ZESCO)}

In April 2003, the Zambian authorities adopted a strategy of commercialization of ZESCO's operations, which is intended to achieve the same objectives as privatization. Understandings were reached with World Bank and Fund staffs in September 2003 on the strategy and on the modalities for monitoring its implementation. The strategy will be reviewed by June 2005 and, if by that time ZESCO does not meet the agreed performance targets, the government is fully committed to implementing a strategy that is consistent with the original objectives of privatization.

The commercialization strategy encompasses four broad areas:

- The revision of legal provisions relating to ZESCO including: (i) an amendment to ZESCO's Articles of Association and the composition of its Board to ensure independence from political interference and to provide a mandate to operate on commercial principles; (ii) revisions to the Electricity Act and to the Energy Regulatory Board (ERB) Act to revise ZESCO's regulatory environment, including greater independence for the ERB; (iii) a separate act to permit ZESCO to enter into private as well as public partnerships.

- Commercial operations: ZESCO is required to operate on a commercial basis and to provide evidence of its capacity to do so - including the formulation and implementation of a business plan and the collection of amounts owed by government; the absence of financial support from government; and tight constraints on government concessional debt guarantees.

- Outstanding obligations: Outstanding obligations are to be settled, including those relating to the mining company, RAMCOZ, central and local government arrears, and ZESCO's outstanding tax liabilities.

- Concessional borrowing: In order to provide ZESCO some breathing space to build a track record of credit worthiness, new borrowing on concessional terms (mainly from the World Bank) guaranteed by the government is permitted up to US\$40 million until the end of 2005. This limit would be subject to review, in consultation with Bank and Fund staff, in the event that additional resources are required.

The strategy for commercialization envisages its implementation in three stages:

- $\quad$ Entry point-Dec 2003: Before approval of the new strategy by World Bank and Fund staff, the government successfully implemented ten measures. These included ZESCO Board approval for amending the Articles of Association and the constitution of a new ZESCO Board with 9 members, of whom only 2 are from the public sector. In addition, while significant tax obligations to the government remain contested, outstanding obligations by government to ZESCO were settled, reducing receivables from 570 to 285 days of revenue. However, further progress is needed on the formulation of a business plan.

- Interim point-June 2004: The strategy envisages the implementation of four measures including the amendment of the ERB Act and the Electricity Act as well as government approval of Ministry of Energy and Water Development's (MEWD) proposals for separate legal acts for private and public partnership.

- Evaluation point-June 2005: The framework envisages the implementation of three further measures prior to a final assessment of the viability of the strategy. These include the ex-post evaluation of ZESCO business plan preparation process, implementation results, and management performance. 
15. The strategy aims to increase real growth to at least 5 percent per annum over the medium term (Figure 2). As discussed in the 2003 Article IV consultation, this target could be attained with further moderate gains in total factor productivity. Growth averaging 5 percent is also feasible in terms of the implied sectoral contributions to growth (see paragraph 14 of the MEFP). Diversification of the economy will be boosted by Zambia's participation in the Common Market of Eastern and Southern Africa (COMESA) and Southern African Development Community (SADC), and by access to industrial markets. Growth will also be boosted by increased production of copper and cobalt, which are

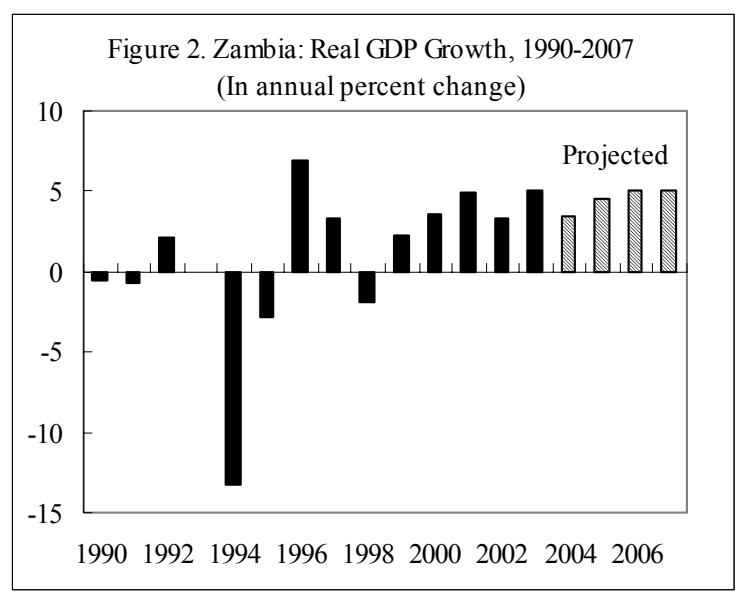
expected to show rapid growth over the next three years, as a result of investments that are now under way, and which may be accelerated in response to higher commodity prices. Other key macroeconomic objectives underlying this medium-term strategy include reducing the rate of inflation to around 10 percent by 2006 and to single digits thereafter; increasing the gross international reserves to around two months of import cover by end-2007; and a narrowing the external current account deficit (including grants and debt relief on interest payments) to a sustainable level.

Zambia: Medium-Term Indicators, 2003-07

(In percent of GDP, unless otherwise indicated)

\begin{tabular}{lrrrrr}
\hline & 2003 & 2004 & 2005 & 2006 & 2007 \\
& Prel. & Proj. & Proj. & Proj. & Proj. \\
\hline Real GDP (annual percentage change) & 5.1 & 3.5 & 4.5 & 5.0 & 5.0 \\
Consumer prices (end of period; percentage change) & 17.2 & 20.0 & 15.0 & 10.0 & 5.0 \\
Revenue (excluding grants) & 18.1 & 18.7 & 18.6 & 18.6 & 18.6 \\
Expenditures (excluding interest) & 27.3 & 23.1 & 24.5 & 24.8 & 25.4 \\
Overall balance, cash basis & -6.6 & -3.4 & -3.2 & -2.4 & -2.4 \\
Domestic financing & 5.1 & 2.2 & 1.2 & 0.9 & 0.5 \\
External current account balance, incl. grants and debt & & & & -3.7 & -3.8 \\
relief & -5.6 & -4.6 & -3.9 & -3.7 \\
Gross official reserves (in months of imports) & 1.3 & 1.0 & 1.5 & 1.7 & 1.9
\end{tabular}

Sources: Zambian authorities; and Fund staff estimates and projections.

16. The government's 2003 report on Zambia's progress toward meeting the MDGs concludes that the objective of halving poverty by 2015 is "unlikely" to be met (Box 2 and Table 3). In the same vein, during the Article IV consultation discussions, it was 


\section{Box 2. Prospects for Reaching the Millennium Development Goals}

Zambia was one of the 191 signatories to the Millennium Declaration at the United Nations Millennium Summit in September 2000 when eight MDGs, to be achieved by 2015, were formulated to guide an effort to overcome human development challenges.

In 2003, the government published a report assessing Zambia's progress towards achieving the MDGs. The report, the first of its kind, was a result of collaboration between the Government of Zambia, civil society, academia, political leaders, and the United Nations System in Zambia. It involved a consultative process among stakeholders, led by a National MDG Task Force comprising the Ministry of Finance and National Planning, Cabinet Office, Civil Society for Poverty Reduction, and the UN Country Team.

The report concludes that Zambia's prospects for achieving the MDGs by 2015 are low. Of the 8 MDGs, the only goal that will 'probably' be reached is the elimination of gender disparity in education, as the ratio of girls to boys in primary and secondary education currently stands at about 94 percent. Goals which could 'potentially' be met, but which would require a significant improvement in efforts, include achieving universal primary education; a two-thirds reduction in child mortality; the halting of HIV/AIDS, malaria, and other diseases; and environmental sustainability. The two MDGs which are 'unlikely' to be met are the halving of poverty and hunger; and a three-fourths reduction in maternal mortality. The proportion of the population below the poverty line remained constant from 1991 to 1998 , while the maternal mortality ratio may actually have increased since 1996.

The report identifies a number of challenges that need to be addressed to make greater progress towards the MDGs :

- To eradicate poverty and hunger, broad-based pro-poor growth is necessary, as well as a poverty focus in resource allocation, which would be facilitated by reaching the HIPC completion point.

- To achieve universal primary education, budget allocations to the education sector need to be increased. Furthermore, trends in HIV/AIDS, which severely affect the sector, need to be reversed.

- To promote gender equality and empower women, strongly entrenched cultural norms need to be addressed through strengthened affirmative action and a changing of attitudes towards women. Female illiteracy and the drop-out of school rate due to pregnancy need to be reduced.

- $\quad$ To reduce child mortality, child health services need to be improved and the high prevalence of HIV/AIDS and malaria need to be reversed.

- To improve maternal health, reproductive health services need to be improved in their quality and accessibility, and cultural practices need to be addressed.

- To combat HIV/AIDS, malaria, and other diseases, human resource constraints, as well as access to care and prevention programs, need to be improved and the stigma associated with HIV/AIDS overcome. Other challenges are the low level of ownership and use of mosquito nets and preventive malaria drugs.

- To ensure environmental sustainability, institutional capacity to enforce laws needs to be strengthened.

- To develop a global partnership for development, a strengthened macroeconomic and public expenditure management environment is necessary to promote support from stakeholders and donors. 
recognized that growth of at least 6-8 percent would be required to reduce poverty in line with the corresponding MDGs (para. 15, Country Report No. 04/214). The government is therefore keenly aware of the need to accelerate structural reforms over the medium term to improve the delivery of government services and remove obstacles to private sector development. However, the staff and the authorities recognized that these reforms would take time to yield a strong private sector response and that it was important to avoid repeating overly optimistic growth projections that were noted in the EPA. The World Bank has taken the lead in Poverty and Social Impact Analysis (PSIA) of reform measures and has completed an analysis of three reform measures in agriculture (Box 3).

\section{The macroeconomic framework does not assume sharply higher assistance over} the medium term, although sustained high levels of external assistance needed to support faster growth are likely to be forthcoming, as policy implementation continues to improve. This cautious approach helps to avoid a repeat of the shortfalls in external budget support, which, as noted in the EPA, hindered program implementation in past arrangements. The projections are in line with the government's MTEF and the current plans of major donors including the World Bank. ${ }^{4}$ Total external assistance, including from the IMF and net of debt service paid, would increase from 5.3 percent of GDP in 2003 to an average of 7.3 percent of GDP over 2004-07 (including additional financing to fill projected financing gaps) but remain well below the average level of 12 percent of GDP seen in the period 1999-2002. Moreover, budget support net of debt-service payments over 2004-07 would be close to zero and thus below the average level of 1.4 percent of GDP received over 1999-2002. However, it is envisaged that higher levels of appropriately concessional assistance could be incorporated into the framework over time to increase priority expenditures and reduce domestic debt.

\begin{tabular}{|c|c|c|c|c|c|c|c|c|c|c|c|c|}
\hline \multicolumn{13}{|c|}{$\begin{array}{l}\text { Zambia: External Financing of the Budget } \\
\text { (In percent of GDP) }\end{array}$} \\
\hline & 1999 & 2000 & 2001 & 2002 & 2003 & 2004 & 2005 & 2006 & 2007 & 1999-02 & 2003 & 2004-07 \\
\hline Net contribution & 1.1 & 2.0 & 0.1 & 2.3 & -1.3 & -1.2 & 0.1 & 0.0 & 0.3 & 1.4 & -1.3 & -0.2 \\
\hline Budget support & 5.7 & 5.7 & 2.1 & 3.7 & 1.3 & 1.3 & 2.0 & 1.7 & 1.9 & 4.3 & 1.3 & 1.7 \\
\hline Program grants & 1.9 & 1.0 & 0.9 & 1.8 & 1.0 & 0.6 & 0.7 & 0.4 & 0.4 & 1.4 & 1.0 & 0.5 \\
\hline Program loans & 3.7 & 4.7 & 1.2 & 1.8 & 0.2 & 0.7 & 0.8 & 0.6 & 0.5 & 2.9 & 0.2 & 0.6 \\
\hline Financing gap & 0.0 & 0.0 & 0.0 & 0.0 & 0.0 & 0.0 & 0.6 & 0.7 & 1.0 & 0.0 & 0.0 & 0.6 \\
\hline Debt service paid & 4.6 & 3.7 & 1.9 & 1.3 & 2.6 & 2.5 & 1.9 & 1.7 & 1.6 & 2.9 & 2.6 & 1.9 \\
\hline Interest & 1.2 & 1.3 & 0.9 & 0.8 & 0.9 & 0.8 & 0.7 & 0.6 & 0.6 & 1.1 & 0.9 & 0.7 \\
\hline Amortization & 3.4 & 2.4 & 1.0 & 0.5 & 1.8 & 1.7 & 1.2 & 1.1 & 1.0 & 1.8 & 1.8 & 1.2 \\
\hline
\end{tabular}

\footnotetext{
4 The Country Assistance Strategy discussed by the Bank's Board on March 9, 2004, starts in a "low" case scenario, reflecting Zambia's weak implementation record during 2003.
} 


\section{Box 3. Poverty and Social Impact Analysis (PSIA)}

The World Bank, which is taking the lead in this area, has jointly with Zambian researchers conducted a PSIA of three key reforms in the agricultural sector, which is seen as the engine of growth and poverty reduction in the PRSP. The Bank's PSIA looks at: (i) improved delivery of rural infrastructure; (ii) reduction/restructuring of fertilizer subsidy; and (iii) rural land reform.

The PSIA finds that improvements in infrastructure have a significant impact on poverty reduction by providing the poor with access to markets for outputs and inputs, opening up new land for cultivation, and increasing the value of and use of land. The improvement of infrastructure also minimizes the need for smallholders to produce food for home consumption, and thus reduces the cost of making cropping decisions based on a "food security first" principle.

In the case of fertilizer, the PSIA found that the subsidies were not well targeted, and that the poor had limited access, while those with access did not always use the fertilizer efficiently. Consistent with this view of the limited effectiveness of the fertilizer subsidy for poverty reduction, the subsidy was reduced from 75 percent to 50 percent in the 2004 budget.

The PSIA found inequities and inefficiencies in the current land distribution system. Although most rural lands are held under traditional tenure, the analysis showed that property rights do exist, to the extent that land is rented out and inherited without formal title. Scrapping the traditional system would eliminate access to justice for most rural dwellers since the traditional chief's powers are linked to the land. Measures to improve accountability of the traditional chiefs should be explored, since the main problems of the existing land tenure system relate to exclusion and gender discrimination.

The PSIA concludes that a coordinated approach to rural development, involving land reform, provision of fertilizer and an improved road network, would raise agricultural productivity and reduce poverty in the rural areas.

In regard to the macroeconomic program and its poverty and social impact, another Bank study on Zambia $^{1}$ examines the income distribution and growth consequences of macroeconomic policies. It concludes that any positive impact on poverty reduction from increases in government spending financed by domestic borrowing is likely to be offset by the adverse impact on growth of crowding-out the private sector. The macroeconomic framework for 2004 is consistent with this conclusion.

${ }^{1}$ Devarajan, Shantayanan, and Go, Delfin S. 2002, “A Macroeconomic Framework for Poverty Reduction Strategy Paper” in The Impact of Economic Policies on Poverty and Income Distribution, ed. By Bourguignon and Pereira da Silva (Washington: World Bank and Oxford University Press). 
18. The centerpiece of the policy framework is a strong, front-loaded fiscal adjustment to halt the unsustainable cycle of rising domestic debt and interest payments, and increase spending on poverty-reducing programs. As called for in the EPA, fiscal policy therefore bears the burden of adjustment. Tax revenues are expected to reach 17.8 percent of GDP in 2004 and remain at this level over the medium term. After a decline in domestic borrowing of 3 percent of GDP in 2004, the strategy envisages a gradual reduction in domestic borrowing to 0.5 percent of GDP by 2007 that should reduce the stock of domestic debt from 21 percent of GDP in 2003 to 14 percent in 2007 (Tables 4 and 5). Reduced domestic interest payments and somewhat higher net aid inflows, including budgetary savings in debt service upon attainment of the completion point under the HIPC Initiative, would provide additional resources for priority programs. In combination with a reorientation in expenditures attained through structural reforms, this would allow an increase in spending on priority poverty-reducing programs from 1 percent of GDP in 2003 to 3.7 percent of GDP in 2007.

19. As was indicated in the 2003 Article IV consultation, with the support of domestic fiscal adjustment and attainment of the completion point under the HIPC Initiative, the medium-term external prospects are generally positive. Copper exports are projected to rise by an average of 15.8 percent a year over 2004-07, due to a continued expansion of production, including new mines in Kansanshi and Lumwana. While this outlook is vulnerable to weaker copper prices, prospects would be bolstered by a successful conclusion of efforts to sell a majority stake in KCM. On this basis, the external current account deficit (after grants and debt relief on interest) is projected to trend down to under 4 percent of GDP in 2007 from about 5.6 percent in 2003 (Table 6).

20. Zambia's external debt-service obligations are projected to remain high in 2004 and 2005, due to large repayments to the Fund, but are projected to become modest in 2006. Assistance under the HIPC Initiative once the completion point is reached, expected in the first half of 2005, will help reduce net debt-service payments from 23.4 percent of exports in 2004 to around 5 percent over the remainder of the PRGF arrangement and will facilitate the recovery of external reserves from their low levels projected at the end of 2004. Cautious assumptions about the level of external assistance, together with the assumption that a higher proportion will be provided through grants, and continued strong gains in exports, will enable the net present value (NPV) of external debt to decline from 181 percent of exports at end2003 to 110 percent in $2007 .^{5}$

21. Financing gaps before debt relief and donors' disbursements are projected to average US\$837 million per year over 2004-07 (Table 7). About a third of this financing

\footnotetext{
${ }^{5}$ For a fuller discussion of Zambia's external debt sustainability, see Box 4 in Country Report No. 04/214.
} 
gap is expected to be filled by debt relief, including additional debt relief that several creditors are expected to provide once the HIPC Initiative completion point is reached. The framework also incorporates US\$543 million each year in assistance from donors, including PRGF disbursements from the Fund, and US\$65 million each year in budget support. Projections for World Bank support under the Country Assistance Strategy (CAS) assume that Zambia will move from the current low case to the base case scenario but there remains scope for further assistance under the high case scenario in 2006-07. Moving to the high case scenario, which could include a poverty reduction and support credit, would require strong performance under the PRGF and in the structural reforms under the Bank's areas of expertise. In conjunction with Public Expenditure Management and Financial Accountability (PEMFA) reforms, the PRGF could catalyze additional budget support from donors over the medium term.

\section{The structural reform agenda covers four main areas that support the objectives of the PRSP and were identified as priorities in the EPA.}

- Reforms in public expenditure management and a restructuring of the public sector will support fiscal consolidation and a reorientation of spending towards poverty reduction.

- Financial sector reforms will support improvement in the efficiency and scope of financial intermediation, including the provision of financial services to rural areas.

- Private sector development will be fostered by completion of the privatization program and a removal of obstacles to private sector growth.

- Continued improvement in governance and in transparency of government operations.

23. The sequencing of these structural reforms reflects the identified priorities and the government's efforts to build ownership. In addition, progress toward stabilization through tackling immediate fiscal priorities would allow administrative capacities to be increasingly focused on "second generation" reforms geared to fostering faster growth:

- The difficulties in fiscal policy implementation in 2003 highlighted the need to strengthen budgetary processes and public expenditure management. The reform agenda in this area is well advanced; the development of the PEMFA program with the close involvement of key donors is also indicative of government ownership of the reform process (Box 4). At the same time, prior cabinet approval of this program is a signal of a commitment to implement reforms that, together with the activity based budgeting, including its wider coverage of poverty-reducing expenditures, will also be important in facilitating increased donor budget support over the medium term. Against this background, PEMFA reforms are emphasized in the first year of the PRGF-supported program. 


\section{Box 4. Public Expenditure Management and Financial Accountability Program}

Public Expenditure Management and Financial Accountability (PEMFA) is one of three priority areas identified under the government's public service reform program. The aim of the PEMFA program is to strengthen and improve public expenditure management and financial accountability. The first step was made in 2001, when the government, in collaboration with the World Bank, undertook the PEMFA diagnostic review. The review highlighted a number of weaknesses including:

(i) predominantly manual financial management systems and weak internal controls; (ii) serious discrepancies between budgeted and actual expenditure; (iii) poor debt management and control of spending arrears; (iv) a need to link medium term fiscal policy and planning to the annual budget process; (v) inadequate and weak institutional framework to ensure the independence of the Auditor General (AuG) and the enforcement of the AuG's its recommendations; (vi) weak public sector procurement oversight and controls. The HIPC Initiative expenditure-tracking Assessment and Action Plan (AAP), carried out jointly by the Government, the World Bank, and the IMF, also concluded that only limited progress had been made in strengthening public expenditure management.

The PEMFA program sets out a roadmap to implement the needed improvements in the following 12 sub-components: (1) Accounting and the Integrated Financial Management Information System (IFMIS); (2) Fiscal Policy and Planning (e.g., the MTEF); (3) Budget Preparation; (4) Budget execution; (5) Debt management; (6) Internal Audit and Control; (7) External Finance Coordination; (8) Legal Framework for the Public Expenditure Management; (9) External Audit; (10) Parliamentary Oversight; (11) Accountancy Training and Regulation; (12) Public Procurement Reform. For each of these components, the program spells out critical issues, objectives, and the next steps to be undertaken, indicating the timing, funding and implementing agencies.

The PEMFA starts in 2004 and is expected to run for at least 5 years. The main priorities, to be implemented in the period 2004-06 include (i) the implementation of the IFMIS to improve reliability and timeliness of financial data and strengthen commitment control over the budget execution; (ii) reform the budget to expand the Activity-Based Budget (ABB) classification to all ministries; (iii) continue to develop a Medium-Term Expenditure Framework (MTEF) anchored in the ABB system; (iv) improve the budget execution system by strengthening the Commitment Control System (CCS); and (v) strengthen internal audit and control also via a strict enforcement of sanctions for noncompliance with the established spending procedures.

Government ownership of the PEMFA program will be key to its success. Cabinet approval of the program and the identification of government institutions to coordinate and manage its different components are positive signs of government commitment to the program. Maintaining a strengthened dialogue with donors and development partners supporting the program, including regular reviews of progress and budgeting and working plans, will also be crucial to the success of PEMFA. Donors and development partners will participate in annual reviews of progress with an independent team of government appointed experts, and representatives of the civil society of Zambia. 
- To consolidate the fiscal adjustment and reorient budgetary spending toward poverty-reducing priorities, the authorities are committed to finalizing and implementing the medium-term strategy for government "rightsizing" and pay reform. These reforms are to be supported by a new structural operation that the World Bank is discussing with the authorities. Progress in developing the strategy in this area, and in designing initial reforms, would be assessed at the time of the first review under the proposed PRGF arrangement. The government has reiterated its commitment to hold the wage bill to no more than 8 percent of GDP over the medium term. Consistent with this limit, the planned "rightsizing" of the civil service will imply a reallocation of resources in line with the PRSP priorities.

- The authorities are holding consultations with the private sector to define a program of measures to improve the environment for private sector development. This process, which was launched earlier this year with the support of the World Bank, ${ }^{6}$ builds upon extensive analytical work already undertaken, and is expected to lead to a comprehensive strategy to tackle obstacles to private sector development (Box 5).

- The authorities' Financial Sector Development Plan (FSDP) has been the subject of widespread consultation (Box 6). This process has enabled a fuller debate of the issues raised in the FSAP, which was conducted in 2002. The final FSDP is to be submitted to cabinet for approval as a prior action for the PRGF arrangement. The initial focus will be on resolving three state-owned NBFIs.

- The government continues to be committed to the policy of zero tolerance for corruption (Appendix I, para. 42). Moreover, to strengthen transparency, the government intends to adhere to budgetary procedures, publish timely reports on budget execution, as well as the government's audited accounts. Finally, the government will seek a constitutional amendment to strengthen the independence of the Office of the Auditor General.

\footnotetext{
${ }^{6}$ Private sector development was identified as one of the three pillars of the World Bank's new Country Assistance Strategy for Zambia.
} 


\section{Box 5. Private Sector Development Initiative}

In order to boost the rate of growth and reduce poverty, the Government of Zambia has launched a private sector development initiative. The aim is to adopt a comprehensive set of reforms that would promote higher levels of domestic and foreign private sector investment. Recommendations from a wide range of studies undertaken in the last two years provide the starting point for this initiative, which is being developed with the participation of the private sector, civil society, donors and government. ${ }^{1}$ A draft private sector development action plan was presented to the Cabinet in May 2004, and will be presented at a Private Sector Development Reform Forum to be held in late June 2004 in Livingstone. At the end of this forum, it is envisaged that action plans will have been developed with timeline and monitoring framework for each of the elements of the reform agenda.

The reform agenda's main objectives are to address existing obstacles to investment through, inter alia, removing regulatory and administrative barriers; strengthening public agencies that service the private sector; rationalizing labor market laws and regulations; modernizing land legislation; improving tax administration increasing transparency and reducing corruption. In addition, the agenda includes steps to foster a more positive environment for the private sector by, for example, reviewing tax incentives and promoting public private partnerships for infrastructure investment. (The latter echoes a concern raised in the authorities' comments on the ex post assessment to the effect that infrastructure weaknesses had not been sufficiently addressed in past programs). Finally, the initiative contemplates sector specific reforms to promote investment in areas identified as having a high growth potential. These include agriculture, tourism, gemstone mining, telecommunications, energy and power, and infrastructure.

Although the development and implementation of the necessary reforms will take time, legislative actions needed to advance some of the key elements of the reform agenda will be presented to Parliament during the second half of 2004. It is envisaged that the immediate priorities to be addressed will be changes to the Investment and Export Processing Zone Acts to bring them in line with new private sector development objectives.

${ }^{1}$ These include a study of Administrative Barriers to Investment, conducted by the Foreign Investment Advisory Services of IFC and the World Bank; The Financial Sector Assessment conducted by the IMF and the World Bank; and World Bank studies of The Challenge of Competitiveness and Diversification and the Copperbelt Diversification Strategy. 


\section{Box 6. Financial Sector Development Plan}

In October 2002, the Government of Zambia constituted a national committee with the participation of key stakeholders to prepare a financial sector development plan (FSDP) with the stated objective of promoting a "stable, sound, and market-based financial system that would support efficient resource mobilization necessary for economic diversification, sustainable growth and poverty reduction." In January 2004, this committee, coordinated by the Bank of Zambia, produced a draft of the FSDP which was posted on the BoZ's websitewww.boz.zm-for comments.

The FSDP makes comprehensive recommendations to address the weaknesses identified from Zambia's participation in the IMF and World Bank Financial Sector Assessment Program (FSAP) and in the BoZ's selfassessment reports. The FSDP focuses on market-based solutions to increase the level of financial intermediation and access to financial services for the poor living in rural areas. The ratio of private sector credit to GDP in 2001 - at 6 percent - was one of the lowest in sub-Saharan Africa, while public sector credit as share of GDP — at 14 percent—was one of the highest.

The FSDP envisages detailed actions to develop the Zambian capital markets, currently dominated by commercial banking activities. In particular, over a period of 2 years, the following measures are indicated as essential:

- Legal modernization: (i) establishment of contemporary bankruptcy, antitrust, consumer protection, accounting and auditing, and corporate governance regimes; (ii) harmonization and strengthening of legislation relating to the financial sector; and (iii) strengthening of provisions to prohibit and prevent money laundering;

- $\quad$ Regulatory strengthening: (i) reinforcement of autonomy of the BoZ in formulating monetary and supervisory policy and in choosing policy instruments; (ii) building up of skills and number of financial sector's employees, in particular in the Pensions and Insurance Authority and in the Security and Exchange Commission; and (iii) development of self-regulation by industry associations as a first line of prudential defense;

- New markets and product development: (i) setting up of a credit reference bureau; (ii) approval of criteria for identifying corporate institutions which qualify to issue tradable financial instruments; (iii) creation of a rating agency; and (iv) issuance of regulations supporting a secondary market for government securities.

In June 2004, the FSDP and a related action plan was finalized and submitted to Cabinet for consideration and approval (a prior action for the PRGF-supported program). Immediate priorities to be addressed include:

- Resolution of insolvent state-owned nonbank financial institutions set up to provide development finance (Development Bank of Zambia), housing finance (Zambia National Building Society), and rural banking (National Savings and Credit Bank);

- Development of the regulatory framework for microfinance institutions. 


\section{Program for 2004}

24. Macroeconomic objectives for 2004 were established in the recently approved budget and the related SMP. These are now reflected in the objectives for the PRGFsupported program which include (i) real GDP growth of about 3.5 percent; (ii) an inflation rate of no more than 20 percent; (iii) a buildup of gross international reserves to about one month of import cover by end-2004. In support of these objectives, the program targets a reduction in the domestic primary deficit to limit domestic borrowing to about 2 percent of GDP and broad money growth to 18 percent of GDP.

\section{Growth is expected to moderate in} 2004 from the revised estimate of 5.1 percent in 2003, reflecting a slower pace of agricultural growth after the recovery in 2003 from the effects of the drought in 2002. The inflation target implies some increase from the outturn for 2003, reflecting developments in food and oil prices. Higher petroleum prices on world markets are expected to have a significant impact on inflation in Zambia, both directly and through rising transport costs to this landlocked nation (Figure 3). In addition, a less favorable trend in food prices will have a large impact due

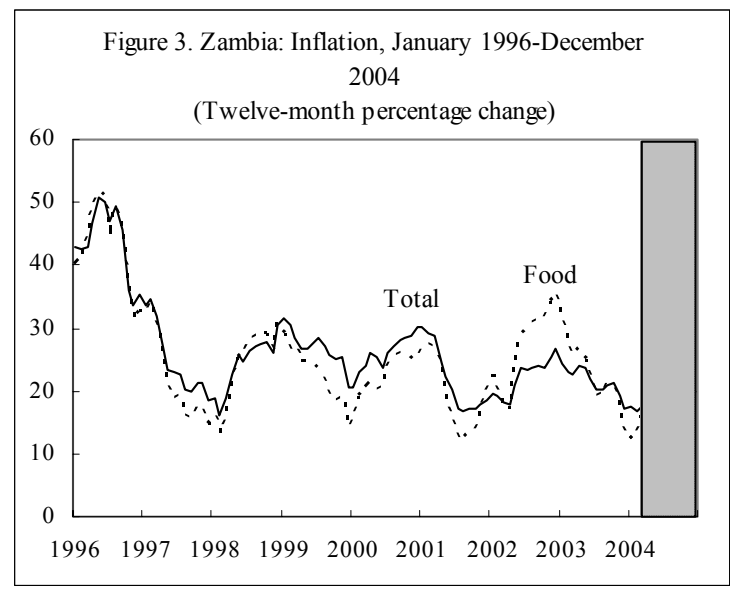
to their weight (more than 50 percent) in the consumer price index.

26. The authorities reiterated their commitment to executing the budget as approved by parliament. The budget targets a 3 percent improvement in the domestic primary balance, to a surplus of 2.4 percent of GDP that will also allow government recourse to domestic financing to decline from 5 percent of GDP in 2003 to 2.2 percent of GDP in 2004. Although the burden of this adjustment falls primarily on the expenditure side, the government intends to increase spending on priority poverty-reducing programs. ${ }^{7}$ A key element of expenditure restraint will be limiting the wage bill to 8 percent of GDP in 2004. In this regard the implementation of a new Payroll Management and Establishment Control (PMEC) system is an important step in controlling the wage bill (para 37 of the MEFP). Savings in recurrent departmental charges are to be achieved by tightening expenditure controls and cutting discretionary spending, especially official travel. Revenue measures focus on broadening the tax base (para. 27 of the MEFP).

\footnotetext{
${ }^{7}$ The program includes a benchmark on payments into the HIPC Initiative account in the Bank of Zambia to fund these expenditures.
} 
27. The government has reiterated its intention to hold the wage bill to no more than 8 percent of GDP in 2004 and, in doing so, it would be also living up to parliament's expectation that it implement the approved budget. Following short-lived strikes by trade unions earlier this year, the issue of government's policy of no general wage increase in 2004 was put before a reconciliation board. The timing and outcome of the board's nonbinding deliberations remain uncertain. However, the challenge that the government now faces is less difficult than in 2003, when there was a need to reopen discussions on remuneration that had already been granted.

28. Since the budget was approved, copper prices have risen above the level of US\$0.96 per pound assumed in the program. ${ }^{8}$ However, this is not expected to have a significant impact on government tax revenues from the sector, which, as a result of concessions granted during privatization, are effectively limited to small royalty payments. In addition, dividends accruing to Zambia Consolidated Copper Mines (ZCCM) holdings, through which the government retains equity in the sector, ${ }^{9}$ will initially be used to defray the holding company's large existing obligations, including those relating to large losses prior to ZCCM's initial privatization.

29. The recent decline in interest rates on treasury bills has led to a downward revision in projected domestic debt service in the second half of the year. However, external debt-service payments, which now include the settlement of arrears from 2003, are projected to be higher than in the budget, largely offsetting the impact of lower domestic interest rates. The possible use of any further net savings will be discussed at the time of the first review under the PRGF arrangement.

30. The monetary program aims to limit broad money growth to 18 percent in 2004, to preserve the gains in reducing inflation in the face of less favorable trends in fuel prices (Tables 8 and 9). As such, the broad money target was set to reduce a monetary overhang from the end of 2003. However, in the light of recent developments, especially the levels of excess liquidity that were prevailing in commercial banks, the reserve money program has been tightened. Thus, consistent with the Bank of Zambia's action to mop up excess liquidity, reserve money growth for the year as a whole is to be limited to under 6 percent. The authorities and the staff concurred that there were uncertainties surrounding the behavior of the money multiplier, which has fluctuated since the decline in reserve requirements, but agreed that it would be prudent for the reserve money program to allow for an increase in the multiplier and thereby provide greater assurance that the broad money

\footnotetext{
${ }^{8}$ The copper price received by Zambia's copper products has average about 3 percent below the price on the London Metal Exchange.

${ }^{9}$ See Box 5, on The Ownership Structure of Konkola Copper Mines, in Country Report No. 04/214.
} 
target could be attained. In this context, it was agreed that the first review would, inter alia, focus on monetary developments.

31. The exchange rate will continue to be market-determined. BoZ intervention in the market will be aimed at smoothing short-term fluctuations and meeting the program's gross international reserves target. Copper producers are expected to accelerate their investment plans in response to higher prices. However, in the short term, higher copper receipts are expected to be largely retained outside Zambia, and would therefore not have a major impact on the supply of foreign exchange to the interbank market.

32. The program is fully financed for 2004. ${ }^{10}$ Approval of a new PRGF arrangement will facilitate first tranche disbursements under a new structural adjustment credit from the World Bank and a new three-year support program from the European Union. The government is also requesting a new Paris Club flow rescheduling agreement on Cologne terms that could be updated to a Cologne stock terms once the completion point is reached.

\section{Structural reforms under the first year of the PRGF arrangement will focus on priorities in the core areas of the Fund's mandate (Box 7). In the fiscal area, the} immediate priorities (MEFP, paras. 35-37) are to support improvements in public expenditure management, which are designed to ensure that the budget plays its rightful role in the definition, implementation, and reporting of government's spending policies. In this vein, the program includes a continuous injunction against extrabudgetary spending as a performance criterion. Approval of the PEMFA program is a prior action for the new PRGF arrangement, and elements of this program to be monitored under the PRGF arrangement in 2004 include (i) the award of a contract for the procurement and installation of software and hardware needed for the full implementation and piloting initiation of the IFMIS in three ministries; (ii) the full integration of the activity-based budget classification in the quarterly budget execution reports, with detailed and summary data on the execution of all poverty-reducing expenditures; and (iii) the improvement of the MTEF as a basis for multiyear financial planning. Strict enforcement of sanctions for noncompliance with spending procedures will be aided by a new monthly reporting system that will improve transparency and accountability (Appendix I, para. 37).

${ }^{10}$ The Paris Club has not yet provided financing assurances, but is expected to do so shortly. 


\section{Box 7. Structural Conditionality}

\section{Coverage of Structural Conditionality in the Current Program}

Prior actions, structural performance criteria and benchmarks for the PRGF-supported program (Appendix I, Tables 3 and 4) focus on areas that are critical for achieving the program's macroeconomic objectives. They include the following:

- Public expenditure management - including: Cabinet approval of the PEMFA program; improved reporting of budget execution; nonpayment of obligations for which the government is not legally liable and which are not included in the budget; awarding a contract for the procurement of hardware and software for IFMIS;

- Strengthen the financial sector-Cabinet approval of an action plan for initial implementation of the Financial Sector Development Plan (FSDP); addressing the weaknesses of the three nonbank financial institutions (NBFIs);

- Tax Policy_Defining a consistent policy framework on the granting of tax exemptions aimed at preventing past errors that have largely exempted the copper sector from taxation;

- Improving transparency and governance-Unforeseen expenditures will be funded only to the limits of the contingency resources indicated in the budget or only after cabinet has approved any changes by finding compensatory funding within the approved budget resources.

\section{Status of Structural Reforms in Earlier Programs}

The status of structural reforms under the SMP during 2003-04 is presented in Table 2 of Appendix I. Most of the structural measures through end-April 2004 were met, with the exception of awarding a contract for the procurement of hardware and software for IFMIS, and agreeing on an action plan for resolving the problems of the three key NBFIs. Both of these areas are now included as conditionality in the PRGF-supported program

\section{Other Structural Conditionality}

World Bank Lending and Conditionality: The World Bank is taking the lead in the following areas:

- Reform of public enterprises, including the commercialization of the electricity utility ZESCO; public sector reforms including pay reform; private sector development issues; public sector pension reform; the public service capacity building project; economic diversification; and improving infrastructure.

- Jointly with the Fund, the Bank will also be involved in financial sector reforms; debt management and domestic debt market development; PRSP monitoring and evaluation; and monitoring progress toward the HIPC Completion point.

The European Union's conditionality includes: (i) progress in implementing the IFMIS; (ii) establishing a Domestic Debt Unit, developing of a debt database, and commencing with the priority areas of domestic debt in line with the Fund-supported program; (iii) and public expenditure review.

Bilateral donors are not currently providing budget support. Improvements in public expenditure management under the PEMFA program are likely to be key to the initiation and maintenance of budget support. 
34. In the financial sector, resolution of state-owned insolvent NBFIs is a priority in 2004. The Zambia National Building Society (ZNBS), the National Savings and Credit Bank (NSCB), and Development Bank of Zambia (DBZ) are all structurally loss-making institutions and, in their present form, pose obstacles to financial sector development. Although together these institutions account for only one percent of the deposits of the financial system, as the FSAP pointed out at the end of 2002, their continuing operations entail risks to depositors, and, to a lesser extent, the budget. In the framework of the FSDP (Appendix I, para. 41), action plans to resolve the three insolvent institutions will be finalized in consultation with IMF and World Bank staff and will be adopted by the government and the Bank of Zambia by October 2004 (performance criterion). Technical assistance is being provided so that decisions on the resolution of these institutions can be informed by a full consideration of alternative options. In addition, the authorities are preparing amendments to the acts regulating the three NBFIs to provide the Bank of Zambia with enhanced regulatory and supervisory powers. These amendments will be approved by the cabinet by November 2004 (structural benchmark) and considered in the December 2004 parliamentary session.

35. In 2004, interventions in the financial sector will also involve the Zambia National Commercial Bank (ZNCB), microfinance operations, and anti-money laundering and combating financing of terrorism (AML/CFT). Specifically, the government is supporting the Zambia Privatization Agency in its efforts to conclude the sale of 49 percent of equity in the ZNCB. To support the operations of banks in rural areas, the Bank of Zambia will implement regulations for microfinance operations. Finally, the authorities are considering, with technical assistance from the Fund, revisions to the Prohibition and Prevention of Money Laundering Act to comply with AML/CFT international best practice, including the revised Financial Action Task Force (FATF) 40 recommendations and the eight special recommendations on terrorist financing.

\section{Access And Phasing}

36. The proposed level of access of $\mathbf{4 5}$ percent of quota is below the average for a third-time user of PRGF resources. This takes into account Zambia's existing high obligations to the Fund and its track record. In view of the profile of financing needs, including debt-service payments to the Fund, the proposed access is also frontloaded (three quarters of total access in the first six months) to ensure a prudent level of reserve cover (Table 10). This exceptional phasing also takes into account satisfactory performance under the SMP for 2004. Prior cabinet approval of the key PEMFA program strengthens the case for this frontloading. The authorities have also agreed that, to facilitate timely repayments of obligations falling due to the Fund, PRGF disbursements in 2004 will be deposited in Zambia's SDR account at the Fund.

\section{CAPACITY TO REPAY THE FUND}

37. Zambia's capacity to meet its financial obligations to the Fund will depend critically on the continued implementation of macroeconomic and structural reforms, 
delivery of HIPC Initiative assistance, and external balance of payments support. However, the proposed access will not increase Fund exposure. Zambia's debt service to the Fund will remain high through 2005 (over SDR 170 million in both 2004 and 2005) due to repayments stemming from the clearance of arrears in 1995, and fall sharply in 2006. The delivery of the remaining HIPC Initiative assistance from the Fund (about SDR 153 million), once the completion point is reached, will help meet these obligations in 2005. Net of debt relief, total external debt obligations including those under a new PRGF arrangement, will decline from 23.4 percent of exports in 2004 to about 7 percent of exports and lower through the rest of the decade. Beyond 2006, obligations to the Fund will trend upwards to reach a peak in 2010 at SDR 81 million or 5 percent of exports. Outstanding obligations to the Fund declined significantly in 2003 to 118 percent of quota, and assuming the HIPC completion point is attained, the proposed level of access would imply a further reduction to 86 percent of quota at the end of 2007 (Table 11). Provided that Zambia reaches the HIPC Initiative completion point in the first half of 2005, external reserves would be adequate to cover total debt-service payments for one year, and will be equivalent to three times the annual external debt service by 2005 .

38. The major risks to Zambia's capacity to repay the Fund stem from possible poor policy performance, uncertainty about copper prices, and the continued growth of nonmining exports, as well as the heavy reliance on external assistance. It will be important for Zambia to reach the completion point under the HIPC Initiative, and that external assistance is on grant terms or highly concessional terms. Zambia's progress toward external sustainability will require firm implementation of reforms over several years and vigilance to ensure that new borrowing is used for key priorities. It is projected that Zambia's gross external financing will remain substantial at about 16 percent of GDP at the end of the decade.

\section{Technical Assistance}

39. In the MEFP, the authorities indicate that they intend to request technical assistance from the Fund to strengthen capacity and support program implementation. In particular, the Ministry of Finance and National Planning is seeking support from FAD on cash management, while the Bank of Zambia has requested MFD's assistance in finalizing the FSDP, resolving the three NBFIs, and implementing the recommendations of the report on AML/CFT. 


\section{STAFF APPRAISAL}

40. Zambia's economic performance has improved markedly in recent years. The country is now enjoying the strongest period of sustained growth in the last three decades, and inflation has fallen to its lowest level in two decades. However, Zambia still faces daunting challenges. Significant progress toward the MDGs will only be possible with faster growth and better targeted public spending. This will, in turn, require consistent and predictable macroeconomic management and further reforms, to improve the efficiency of government operations and the environment for private sector activity, thereby engendering increased donor inflows and higher private investment.

\section{In 2003, Zambia's still fragile macroeconomic stability was jeopardized by} severe policy setbacks. Large expenditure overruns, stemming from spending decisions outside the framework of the budget, resulted in correspondingly excessive recourse to domestic borrowing. As a result, domestic debt and the burden of domestic interest payments in the budget both increased sharply. At the same time, these large slippages precluded consideration in 2003 of a new PRGF arrangement that could have been the catalyst for higher inflows of external budget support and facilitated the attainment of the completion point under the HIPC Initiative.

\section{The authorities have taken decisive action to safeguard macroeconomic stability} and the credibility of policymaking. During 2003, the government took the very difficult step of reopening negotiations on increases in the remuneration of government employees, and reducing payments of housing allowances to more affordable levels. As a result, the total wage bill, which has risen sharply in recent years, was held to 8.5 percent of GDP in 2003. The approved budget for 2004 calls for a sharp fiscal consolidation to limit recourse to domestic borrowing. The government has again taken a firm stand, by resisting a general wage increase in 2004, limiting the wage bill to 8 percent of GDP in line with the budget, and providing more room for priority spending. The initial results of fiscal policy implementation were positive.

\section{Performance, so far, under the SMP attests to the authorities' determination to} avoid ad hoc spending decisions that plagued implementation last year. This process was aided by the authorities' greater ownership of the program that emerged from an intense debate over the budget in the cabinet and parliament. The development of a PEMFA program, with the close involvement of key donors, is an indication of greater government ownership of the reform process. In addition, the President's strong backing for the reforms aided implementation. Policy coordination was strengthened by the creation of an interministerial monitoring committee, with a secretariat in which the Fund's Resident Representative participates. Against this background and with continued performance toward program targets in April and May, the authorities have demonstrated their resolve to implement their program and it is therefore proposed to move ahead with a PRGF arrangement. 
44. The authorities' program is an appropriate response to the urgent need for a fiscal adjustment. Improvements of the MTEF process and the strengthened accountability facilitated by the greater transparency of activity based budgeting should both contribute to consolidate stability and provide greater scope for priority spending. In this context, the authorities are urged to resist pressures for higher wage payments in 2004 and continue to hold rigidly to the expenditure limits implied by the budget.

45. The monetary program is supportive of the objective of containing inflationary pressures in the face of expected increases in petroleum prices. The success, to date, in controlling broad money growth in line with program targets is welcome. However, the BoZ must pay close attention to movements in the commercial banks' liquidity ratios and mop up excess liquidity, in line with the reserve money program, to fend off the potential for excess credit and monetary expansion.

46. The authorities are encouraged to work closely with donors to ensure prompt and effective implementation of the initial steps in the PEMFA program. As well as being crucial in its own right to support improved public expenditure management, successful implementation would be an important step toward obtaining higher levels of external budget support needed to support progress toward meeting the MDGs. Given Zambia's capacity constraints, staff also notes that a successful implementation of the program hinges on a prioritized action plan for the PEMFA program. Similarly, the authorities are urged to expedite the preparation of plans for rightsizing and pay reform with the assistance of the World Bank and other donors. Progress in this area will be crucial to ensure effective public services delivery by a better paid, but affordable, government apparatus. Finally, the authorities are urged to strictly enforce sanctions for violations of financial regulations and procedures.

47. The authorities should continue to improve the environment for private sector development and foreign investment. In this regard, the fuller elaboration, through the process of consultation now underway in the Private Sector Development Initiative, of a strategy and action plan to remove obstacles to both domestic and foreign private investment, is crucial. It will be important to draw on work that has already been conducted to identify and begin addressing priority areas. In this context, it is important to define a consistent policy for tax exemptions that achieves a prudent balance between the desire to encourage productive investment and the risk that exemptions could rapidly undermine Zambia's so far resilient revenue base. In particular, it is essential to guard against a repeat of the exemptions granted in the copper sector, which have undermined revenues from this sector.

48. The completion of the FSDP is an important step toward addressing the issues identified in the FSAP. The authorities are encouraged to prioritize the challenges and ensure that urgent issues, such as the insolvency of the NBFIs, are addressed in 2004. Progress toward the sale of the ZNCB is warmly welcomed. 
49. The proposed access and phasing strikes an appropriate balance between the need to support Zambia's efforts to achieve sustained growth to reduce poverty and the risks to the Fund. The exceptional degree of frontloading is justified to safeguard Zambia's reserve position in 2004 - when debt service payments, stemming from the settlement of arrears in 1995, are high — while providing much lower access when Zambia's needs are subsequently much lower. Nevertheless, the risks are considerable in view of past policy slippages, vulnerability to stocks, and overindebtedness. Performance under the SMP mitigates, to a degree, the immediate policy risks, but several years of good performance will be necessary. 
Table 1. Zambia: Selected Economic and Financial Indicators, 2002-2007

\begin{tabular}{|c|c|c|c|c|c|c|}
\hline & $\begin{array}{r}2002 \\
\text { Est. }\end{array}$ & $\begin{array}{r}2003 \\
\text { Est. }\end{array}$ & $\begin{array}{l}2004 \\
\text { Prog. }\end{array}$ & $\begin{array}{l}2005 \\
\text { Proj. }\end{array}$ & $\begin{array}{l}2006 \\
\text { Proj. }\end{array}$ & $\begin{array}{l}2007 \\
\text { Proj. }\end{array}$ \\
\hline & \multicolumn{5}{|c|}{ (Annual percentage change, unless otherwise indicated) } & \\
\hline \multicolumn{7}{|l|}{ National income and prices } \\
\hline Real GDP & 3.3 & 5.1 & 3.5 & 4.5 & 5.0 & 5.0 \\
\hline GDP deflator & 19.9 & 20.1 & 20.4 & 13.9 & 10.5 & 6.0 \\
\hline Consumer prices (annual average) & 22.2 & 21.5 & 18.5 & 17.4 & 12.6 & 7.6 \\
\hline Consumer prices (end of period) & 26.7 & 17.2 & 20.0 & 15.0 & 10.0 & 5.0 \\
\hline \multicolumn{7}{|l|}{ External sector } \\
\hline U.S. dollar value of exports of goods and services & 2.4 & 23.4 & 21.5 & 12.6 & 8.4 & 1.4 \\
\hline U.S. dollar value of imports of goods and services & -2.5 & 13.3 & 13.7 & 10.9 & 5.6 & 2.7 \\
\hline Export volume & 11.1 & 9.4 & 4.9 & 16.8 & 12.0 & 0.9 \\
\hline Import volume & -4.3 & 7.4 & 7.7 & 15.3 & 9.8 & 2.5 \\
\hline Copper export volume & 11.3 & 7.1 & 8.0 & 22.9 & 14.8 & 4.5 \\
\hline Copper export prices (average, U.S. dollars per pound) & 0.70 & 0.78 & 0.96 & 0.92 & 0.88 & 0.86 \\
\hline Nominal effective exchange rate (annual average) 1 / & -19.3 & -14.5 & -13.5 & $\ldots$ & $\ldots$ & $\ldots$ \\
\hline Real effective exchange rate (annual average) 1 / & -5.8 & -0.8 & -0.2 & $\ldots$ & $\ldots$ & $\ldots$ \\
\hline Terms of trade & -7.0 & 5.0 & 10.7 & -0.2 & 0.7 & -0.1 \\
\hline \multicolumn{7}{|l|}{ Money and credit (change in percent of beginning-of-year M2) } \\
\hline Net foreign assets & 68.5 & -9.0 & 0.0 & $\ldots$ & $\ldots$ & $\ldots$ \\
\hline Net domestic assets & -37.0 & 32.5 & 18.1 & $\ldots$ & $\ldots$ & $\ldots$ \\
\hline Net domestic credit & -29.4 & 36.6 & 18.8 & $\ldots$ & $\ldots$ & $\ldots$ \\
\hline Net claims on government & 3.1 & 27.0 & 9.7 & $\ldots$ & $\ldots$ & $\ldots$ \\
\hline Claims on nongovernment & 6.1 & 9.6 & 9.1 & $\ldots$ & $\ldots$ & $\ldots$ \\
\hline Broad money & 31.5 & 23.4 & 18.1 & $\ldots$ & $\ldots$ & $\ldots$ \\
\hline \multicolumn{7}{|l|}{ Central government budget } \\
\hline Revenue (excluding grants) & 16.0 & 26.5 & 30.0 & 18.3 & 16.3 & 11.3 \\
\hline Grants & 79.0 & 5.5 & -2.5 & 44.1 & 21.2 & 12.8 \\
\hline Expenditures 2/ & 22.8 & 22.5 & 10.2 & 23.8 & 14.2 & 11.4 \\
\hline \multirow[t]{2}{*}{ Domestic expenditures 2/3/ } & 14.1 & 23.9 & 17.5 & 24.1 & 13.6 & 11.0 \\
\hline & \multicolumn{6}{|c|}{ (In percent of GDP) } \\
\hline \multicolumn{7}{|l|}{ Investment and savings } \\
\hline Gross national savings 4/ & 16.5 & 20.6 & 18.6 & 16.9 & 16.6 & 15.4 \\
\hline Gross foreign savings 5 / & 6.5 & 5.6 & 4.6 & 3.9 & 3.7 & 3.8 \\
\hline Gross domestic investment & 23.0 & 26.2 & 23.3 & 20.8 & 20.3 & 19.2 \\
\hline Of which: public investment & 11.8 & 11.5 & 9.2 & 10.0 & 10.5 & 11.5 \\
\hline \multicolumn{7}{|l|}{ Central government budget } \\
\hline Revenue and grants & 26.2 & 25.1 & 24.1 & 25.2 & 25.5 & 25.6 \\
\hline Revenue (excluding grants) & 17.9 & 18.1 & 18.7 & 18.6 & 18.6 & 18.6 \\
\hline Expenditures (excluding interest) $2 /$ & 27.8 & 27.3 & 23.1 & 24.5 & 24.8 & 25.4 \\
\hline Interest due $4 /$ & 4.1 & 3.9 & 4.2 & 3.9 & 3.1 & 2.6 \\
\hline Domestic expenditures $2 / 3$ / & 21.3 & 21.0 & 19.7 & 20.5 & 20.1 & 20.0 \\
\hline Overall balance, cash basis & -6.3 & -6.6 & -3.4 & -3.2 & -2.4 & -2.4 \\
\hline Domestic balance, cash basis 5 / & -4.1 & -3.5 & -1.0 & -1.9 & -1.4 & -1.4 \\
\hline \multicolumn{7}{|l|}{ External sector } \\
\hline Current account balance, excl. grants & -17.3 & -14.3 & -11.4 & -11.6 & -11.5 & -11.9 \\
\hline Current account balance, incl. grants and debt relief 6 / & -6.5 & -5.6 & -4.6 & -3.9 & -3.7 & -3.8 \\
\hline \multicolumn{7}{|c|}{ (In percent of exports of goods and services) } \\
\hline \multicolumn{7}{|l|}{ External debt } \\
\hline External official debt service & 11.4 & 14.1 & 23.4 & 5.5 & 4.4 & 5.5 \\
\hline \multirow[t]{2}{*}{ External program assistance 7/ } & 12.8 & 4.1 & 4.3 & 4.3 & 2.9 & 2.8 \\
\hline & \multicolumn{5}{|c|}{ (In millions of U.S. dollars, unless otherwise indicated) } & \\
\hline Current account balance, incl. grants and debt relief 6 / & -246 & -241 & -238 & -207 & -212 & -232 \\
\hline Overall balance of payments & -383 & -321 & -283 & -216 & -225 & -205 \\
\hline Gross official reserves (end of period) & 283 & 197 & 173 & 277 & 334 & 392 \\
\hline In months of imports of goods and services & 2.2 & 1.3 & 1.0 & 1.5 & 1.7 & 1.9 \\
\hline
\end{tabular}

Sources: Zambian authorities; and Fund staff estimates and projections.

1/ For 2004, figures represent 12-month average to January.

$2 /$ Including contingency reserve and payments of domestic arrears.

3/ Excludes external interest payments and foreign-financed capital expenditure.

4/ After enhanced HIPC Initiative debt relief.

5/ Excludes foreign grants, external interest payments, and foreign-financed capital expenditure.

6/ Includes program and budget grants and debt relief on interest payments.

7/ For 2005-07, figures are preliminary projections and only include identified commitments. 
Table 2. Zambia: Status of Key Reform Objectives for Reaching the Floating Completion Point Under the Enhanced HIPC Initiative

\begin{tabular}{|c|c|}
\hline Reform Objectives/Measures & Status \\
\hline \multicolumn{2}{|l|}{ Poverty reduction } \\
\hline $\begin{array}{l}\text { - The adoption of a PRSP to be prepared through a participatory process, and satisfactory progress } \\
\text { with implementing and monitoring the PRSP for at least one year based on annual report. }\end{array}$ & $\begin{array}{l}\text { The PRSP was prepared, and implementation } \\
\text { is ongoing. The first annual progress report } \\
\text { was completed in April 2004. Progress in }\end{array}$ \\
\hline Social sectors & implementing and monitoring the PRSP was limited. \\
\hline \multicolumn{2}{|l|}{ Progress in combating HIV/AIDS } \\
\hline - full staffing of secretariat to National HIV/AIDS/STD/TB Council. & Implemented \\
\hline $\begin{array}{l}\text { - integrate HIV/AIDS awareness and prevention programs in the pre-service and in-service } \\
\text { programs of at least ten key ministries. }\end{array}$ & Implemented \\
\hline \multicolumn{2}{|l|}{ Progress in education sector reform as indicated by the following: } \\
\hline $\begin{array}{l}\text { - increasing the share of education in the discretionary budget from } 18.5 \text { percent in } 1999 \\
\text { to at least } 20.5 \text { percent. }\end{array}$ & $\begin{array}{l}\text { The ratio was met in } 2001 \text {, but it fell to } \\
18 \text { percent in } 2002 \text {. Government plans } \\
\text { to meet this ratio by end } 2004 \text {. }\end{array}$ \\
\hline $\begin{array}{l}\text { - raising the starting compensation of teachers in rural areas above the poverty line } \\
\text { for a household, as defined by the Central Statistical Office. }\end{array}$ & Implemented \\
\hline $\begin{array}{l}\text { - an action plan for increasing student retention in northern, eastern, northwestern, and western } \\
\text { provinces, and Luapula Province. }\end{array}$ & Observed \\
\hline \multicolumn{2}{|l|}{ Progress in health sector reform as indicated by: } \\
\hline - implementation and scaling up of an action plan for malaria; & Implemented \\
\hline $\begin{array}{l}\text { - procedures and mechanisms for the procurement of drugs reorganized to be fully transparent } \\
\text { and efficient; }\end{array}$ & Implemented \\
\hline - timely release of complete, detailed, annual health expenditure data; and & Implemented \\
\hline $\begin{array}{l}\text { - actual cash releases to District Health Management Boards shall be at least } 80 \text { percent of } \\
\text { amount budgeted. }\end{array}$ & Implemented \\
\hline \multicolumn{2}{|l|}{ Macroeconomic and structural reforms } \\
\hline $\begin{array}{l}\text { - Maintenance of a stable macroeconomic environment, as evidenced by satisfactory performance } \\
\text { under a program supported by PRGF arrangement. }\end{array}$ & $\begin{array}{l}\text { Observed for 2002. Performance in } 2003 \text { was } \\
\text { unsatisfactory. Implementation of an SMP in } \\
\text { the first quarter of } 2004 \text { was on track. }\end{array}$ \\
\hline $\begin{array}{l}\text { - Implementation of an Integrated Financial Management Information System (IFMIS) on a } \\
\text { pilot basis for at least three ministries and a midterm review of the pilot program. }\end{array}$ & $\begin{array}{l}\text { Procurement of hardware and software } \\
\text { for IFMIS is expected around mid- } 2004 \text {. } \\
\text { Piloting in three line ministries is expected } \\
\text { to start thereafter. }\end{array}$ \\
\hline $\begin{array}{l}\text { - Implementation of a Medium-Term Expenditure Framework (MTEF) prepared by } \\
\text { MoFED and approved by the Cabinet. }\end{array}$ & $\begin{array}{l}\text { A MTEF for 2004-06 was prepared; Cabinet approved } \\
\text { the MTEF along with the } 2004 \text { budget parameters. } \\
\text { Preparation of the 2005-07 MTEF is ongoing. }\end{array}$ \\
\hline $\begin{array}{l}\text { - Restructuring and issue of international bidding documents for the sale of a majority (controlling) } \\
\text { interest in the power company, ZESCO. }\end{array}$ & $\begin{array}{l}\text { The government is implementing a strategy to } \\
\text { commercialize ZESCO to meet the same } \\
\text { objectives as privatization. }\end{array}$ \\
\hline $\begin{array}{l}\text { - Issuance of international bidding documents for the sale of a majority (controlling) interest in the } \\
\text { Zambian National Commercial Bank. }\end{array}$ & $\begin{array}{l}\text { Implemented. Negotiations for sale to the } \\
\text { preferred bidder are continuing. }\end{array}$ \\
\hline
\end{tabular}

Source: Zambian authorities and staff assessment. 
Table 3. Zambia: Millenium Development Goals

\begin{tabular}{rrrrr}
\hline & 1990 & 1995 & $2001 \quad 2002$ & 2015 \\
& Target
\end{tabular}

Goal 1. Eradicate extreme poverty and hunger

Target 1: Halve, between 1990 and 2015, the proportion of people whose income is less than one dollar a day

1. Population below US\$1 a day (percent)

2. Poverty gap ration at US\$1 a day (percent)

3. Share of income or consumption held by poorest 20 percent (percent)

Target 2: Halve, between 1990 and 2015, the proportion of people suffering hunger

4. Prevalence of child malnutrition (percent of children under 5)

5. Population below minimum level of dietary energy consumption (percent)
25.2

45.0

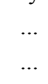

$\cdots$

$$
\cdots
$$

Goal 2. Achieve universal primary education

Target 3: Ensure that, by 2015, children will be able to complete a full course of primary schooling

6 . Net primary enrollment ratio (percent of relevant age group)

7. Percentage of cohort reaching grade 5 (percent)

8. Youth literacy rate (percent ages 15-24)

$\begin{array}{rrr}\ldots & 74.8 & 65.5 \\ \ldots & \ldots & 80.6 \\ 81.2 & 85.1 & 88.7\end{array}$

$\cdots$

...

89.2

\section{Goal 3. Promote gender equality and empower women}

Target 4: Eliminate gender disparity in primary and secondary education preferably by 2005 and to all levels of education by 2015

9. Ratio of girls to boys in primary and secondary education (percent)

10. Ratio of young literate females to males (percent ages 15-24)

11. Share of women employed in the nonagricultural sector (percent)

12. Proportion of seats held by women in the national parliament (percent)

$\begin{array}{rrrr}\ldots & \cdots & 92.4 & \ldots \\ 88.1 & 91.5 & 94.6 & 95.0 \\ \ldots & \ldots & \ldots & \ldots \\ 7.0 & 10.0 & 10.0 & 12.0\end{array}$

\section{Goal 4. Reduce child mortality}

Target 5: Reduce by two-thirds, between 1990 and 2015, the under-five mortality rate

13. Under-five mortality rate (per 1,000)

$192.0 \quad 202.0 \quad 202.0$

108.0

112.0

112.0

15. Immunization against measles (percent of children under 12 months)

90.0

86.0

85.0

\section{Goal 5. Improve maternal health}

Target 6: Reduce by three-quarters, between 1990 and 2015, the maternal mortality ratio

16. Maternal mortality ratio (modeled estimate, per 100,000 live births)

17. Proportion of births attended by skilled health personnel

$\begin{array}{ll}\cdots & 870.0\end{array}$

\section{Goal 6. Combat HIV/AIDS, malaria and other diseases}

Target 7: Halt by 2015, and begin to reverse, the spread of HIV/AIDS

18. HIV prevalence among females (percent ages 15-24)

19. Contraceptive prevalence rate (percent of women ages 15-49)

20. Number of children orphaned by HIV/AIDS (in thousands)

Target 8: Halt by 2015 , and begin to reverse, the incidence of malaria and other major diseases

21. Prevalence of death associated with malaria

22. Share of population in malaria risk areas using effective prevention and treatment

23. Incidence of tuberculosis (per 100,000 people)

24. Tuberculosis cases detected under DOTS (percent) 
Table 3. Zambia: Millenium Development Goals (concluded)

\begin{tabular}{rrrrr}
\hline & 1990 & 1995 & $2001 \quad 2002$ \\
Target & & & \\
\hline
\end{tabular}

Goal 7. Ensure environmental sustainability

Target 9: Integrate the principles of sustainable development into policies and programs. Reverse the loss of environmental resources. 25. Forest area (percent of total land area)

26. Nationally protected areas (percent of total land area)

27. GDP per unit of energy use (PPP \$ per kg oil equivalent)

28. CO2 emissions (metric tons per capita)

29. Proportion of population using solid fuels

30. Access to improved water source (percent of population)

Target 11: Achieve by 2020 significant improvement for at least 100 million slum dwellers

31 . Access to improved sanitation (percent of population)

32. Access to secure tenure (percent of population)

Goal 8. Develop a Global Partnership for Development 1/

Target 16: Develop and implement strategies for productive work for youth

45. Unemployment rate of population ages 15-24 (total)

Female

Male

Target 17: Provide access to affordable essential drugs

46. Proportion of population with access to affordable essential drugs

Target 18: Make available new technologies, especially information and communications 47. Fixed line and mobile telephones (per 1,000 people)

48. Personal computers (per 1,000 people)
53.5

...

1.1

0.3

52.0

$\begin{array}{rr}\cdots & 42.0 \\ 8.6 & 8.6\end{array}$

$\begin{array}{ll}8.6 & 8.6 \\ 1.1 & 1.2\end{array}$

$0.3 \quad 0.2$

61.0

$\cdots$

...

$\begin{array}{ll}\cdots & 64.0\end{array}$

$\begin{array}{llll}63.0 & \ldots & 78.0 & \ldots\end{array}$

$\begin{array}{llll} & \ldots & \ldots & \ldots\end{array}$

Sources: World Bank; and Fund staff estimates.

1/ Targets 12-15 and indicators 33-44 are excluded because they cannot be measured on a country-specific basis. These are related to official development assistance, market access, and the HIPC initiative. 
Table 4. Zambia: Central Government Overall Operations, 2002-07 (In billions of kwacha)

\begin{tabular}{|c|c|c|c|c|c|c|}
\hline & 2002 & $\begin{array}{c}2003 \\
\text { Prel. }\end{array}$ & $\begin{array}{l}2004 \\
\text { Prog. }\end{array}$ & $\begin{array}{l}2005 \\
\text { Proj. }\end{array}$ & $\begin{array}{l}2006 \\
\text { Proj. }\end{array}$ & $\begin{array}{l}2007 \\
\text { Proj. }\end{array}$ \\
\hline Revenue and grants & 4,259 & 5,104 & 6,172 & 7,660 & 9,007 & 10,061 \\
\hline Revenue & 2,909 & 3,680 & 4,784 & 5,660 & 6,583 & 7,327 \\
\hline Tax revenue & 2,849 & 3,548 & 4,547 & 5,432 & 6,300 & 7,010 \\
\hline Income taxes & 1,244 & 1,622 & 2,049 & 2,450 & 2,842 & 3,154 \\
\hline Excise taxes & 423 & 482 & 615 & 734 & 852 & 950 \\
\hline Value-added tax (VAT) & 812 & 1,034 & 1,373 & 1,640 & 1,902 & 2,120 \\
\hline Domestic VAT & 342 & 393 & 608 & 725 & 841 & 938 \\
\hline Import VAT & 471 & 642 & 766 & 914 & 1,060 & 1,182 \\
\hline Customs duty & 367 & 409 & 509 & 608 & 705 & 786 \\
\hline Nontax revenue & 60 & 132 & 239 & 228 & 284 & 316 \\
\hline Grants & 1,350 & 1,424 & 1,388 & 2,000 & 2,424 & 2,735 \\
\hline Program & 324 & 229 & 163 & 386 & 341 & 342 \\
\hline Project & 1,026 & 1,195 & 1,225 & 1,614 & 2,082 & 2,392 \\
\hline Expenditures & 5,086 & 6,337 & 6,981 & 8,643 & 9,872 & 10,995 \\
\hline Current expenditures & 3,161 & 4,002 & 4,640 & 5,594 & 6,149 & 6,481 \\
\hline Wages and salaries & 1,301 & 1,728 & 2,018 & 2,419 & 2,778 & 3,046 \\
\hline Public service retrenchment & 80 & 10 & 33 & 39 & 48 & 60 \\
\hline Recurrent departmental charges (RDCs) 1/ & 584 & 648 & 686 & 1,075 & 1,263 & 1,322 \\
\hline Arrears clearance & 147 & 52 & 77 & 183 & 187 & 170 \\
\hline Awards and Compensations (Court decisions) & 0 & 15 & 20 & 30 & 40 & 50 \\
\hline Elections \& constitutional review & 0 & 0 & 26 & 67 & 126 & 12 \\
\hline HIPC financed & 11 & 0 & 0 & 100 & 100 & 120 \\
\hline Other RDCs & 426 & 564 & 545 & 695 & 810 & 970 \\
\hline Transfers and pensions & 412 & 361 & 419 & 493 & 557 & 600 \\
\hline Of which : HIPC financed & 21 & 0 & 0 & 1 & 0 & 0 \\
\hline Of which: Settlement of statutory pension arrears & 0 & 5 & 30 & 36 & 42 & 46 \\
\hline Domestic interest & 450 & 563 & 855 & 974 & 870 & 784 \\
\hline External interest 2/ & 210 & 229 & 213 & 223 & 227 & 221 \\
\hline Other current expenditures & 95 & 456 & 405 & 352 & 382 & 412 \\
\hline Non-PRP current expenditures & 52 & 456 & 250 & 268 & 284 & 292 \\
\hline Of which: financial restructuring & 0 & 209 & 120 & 120 & 120 & 120 \\
\hline PRP current expenditures & 43 & 0 & 155 & 84 & 98 & 120 \\
\hline Contingency & 29 & 6 & 11 & 18 & 24 & 36 \\
\hline Capital expenditure & 1,925 & 2,335 & 2,341 & 3,049 & 3,722 & 4,515 \\
\hline Domestically financed & 417 & 507 & 601 & 871 & 1,167 & 1,607 \\
\hline Of which: HIPC financed & 79 & 213 & 378 & 607 & 840 & 1,235 \\
\hline Foreign financed & 1,508 & 1,828 & 1,740 & 2,177 & 2,555 & 2,907 \\
\hline Change in balances and statistical discrepancy $(-=$ overfin. $) 3 /$ & -204 & -116 & -70 & 0 & 0 & 0 \\
\hline Overall balance (cash basis) & $-1,031$ & $-1,349$ & -879 & -983 & -865 & -934 \\
\hline Overall balance excluding grants & $-2,177$ & $-2,657$ & $-2,197$ & $-2,983$ & $-3,288$ & $-3,669$ \\
\hline Domestic balance & -458 & -600 & -244 & -583 & -506 & -541 \\
\hline Domestic primary balance & -8 & -36 & 611 & 392 & 364 & 243 \\
\hline Financing & 1,031 & 1,349 & 879 & 812 & 616 & 543 \\
\hline Domestic 4/ & 337 & 1,041 & 573 & 365 & 318 & 209 \\
\hline Bank & 90 & 979 & 434 & $\ldots$ & $\ldots$ & $\ldots$ \\
\hline Nonbank & 247 & 62 & 139 & $\ldots$ & $\ldots$ & $\ldots$ \\
\hline External & 693 & 308 & 306 & 447 & 298 & 334 \\
\hline Program loans & 295 & 46 & 181 & 236 & 207 & 215 \\
\hline Project loans & 483 & 633 & 548 & 563 & 473 & 515 \\
\hline Amortization 2/ & -84 & -371 & -423 & -352 & -382 & -396 \\
\hline Financing gap 5/ & 0 & 0 & 0 & 171 & 249 & 391 \\
\hline \multicolumn{7}{|l|}{ Memorandum items: } \\
\hline Priority poverty-reducing spending & 154 & 213 & 534 & 792 & 1,038 & 1,475 \\
\hline External budget support & 619 & 159 & 344 & 792 & 797 & 948 \\
\hline Stock of domestic arrears (end period) & 602 & 747 & 670 & 487 & 299 & 129 \\
\hline Stock of domestic debt (end period) 6/ & 3,408 & 4,263 & 5,187 & 5,265 & 5,403 & 5,569 \\
\hline GDP & 16,260 & 20,520 & 25,578 & 30,444 & 35,340 & 39,333 \\
\hline
\end{tabular}

Sources: Zambian authorities; and Fund staff estimates and projections.

1/ Recurrent Departmental Charges include purchases of goods and service, some allowances and training expenses.

2/ The last Paris Club rescheduling agreement providing debt relief on Cologne flow terms expired at end-March 2003. Zambia is expected to accumulate external arrears on rescheduable debt until a new Paris Club agreement on Cologne flow terms is in place, following the approval of the PRGF arrangement. Once the completion point under the HIPC Initiative is reached, the Paris Club is expected to provide debt relief on Cologne stock terms.

3/ Payments to RAMCOZ employees for retrenchment (K 70 billion) released in Q4 2003 were cashed in Q1 2004.

4/ Until 2003 at face value. From 2004 at cost value. Excludes bonds issued in 2001 in favor of the Bank of Zambia (K 1,646 billion) and in 2002 in favor of the Zambia National Commercial Bank (K 248 billionn).

5/ The projected financing gaps in 2005-07 are expected to be covered by additional support from donors.

6/ At cost value. Include bonds issued in 2001 in favor of BoZ (K 1,646 billion) and in 2002 in favor of the Zambia National Commercial Bank (K 248 billion). 
Table 5. Zambia: Central Government Overall Operations, 2002-07 (In percent of GDP, unless otherwise indicated)

\begin{tabular}{|c|c|c|c|c|c|c|}
\hline & 2002 & $\begin{array}{c}2003 \\
\text { Prel. }\end{array}$ & $\begin{array}{l}2004 \\
\text { Prog. }\end{array}$ & $\begin{array}{l}2005 \\
\text { Proj. }\end{array}$ & $\begin{array}{l}2006 \\
\text { Proj. }\end{array}$ & $\begin{array}{l}2007 \\
\text { Proj. }\end{array}$ \\
\hline & 26.2 & 24.9 & 24.1 & 25.2 & 25.5 & 25.6 \\
\hline Revenue & 17.9 & 17.9 & 18.7 & 18.6 & 18.6 & 18.6 \\
\hline Tax revenue & 17.5 & 17.3 & 17.8 & 17.8 & 17.8 & 17.8 \\
\hline Income taxes & 7.6 & 7.9 & 8.0 & 8.0 & 8.0 & 8.0 \\
\hline Excise taxes & 2.6 & 2.3 & 2.4 & 2.4 & 2.4 & 2.4 \\
\hline Value-added tax (VAT) & 5.0 & 5.0 & 5.4 & 5.4 & 5.4 & 5.4 \\
\hline Domestic VAT & 2.1 & 1.9 & 2.4 & 2.4 & 2.4 & 2.4 \\
\hline Import VAT & 2.9 & 3.1 & 3.0 & 3.0 & 3.0 & 3.0 \\
\hline Customs duty & 2.3 & 2.0 & 2.0 & 2.0 & 2.0 & 2.0 \\
\hline Nontax revenue & 0.4 & 0.6 & 0.9 & 0.7 & 0.8 & 0.8 \\
\hline Grants & 8.3 & 6.9 & 5.4 & 6.6 & 6.9 & 7.0 \\
\hline Program & 2.0 & 1.1 & 0.6 & 1.3 & 1.0 & 0.9 \\
\hline Project & 6.3 & 5.8 & 4.8 & 5.3 & 5.9 & 6.1 \\
\hline Expenditures & 31.3 & 30.9 & 27.3 & 28.4 & 27.9 & 28.0 \\
\hline Current expenditures & 19.4 & 19.5 & 18.1 & 18.4 & 17.4 & 16.5 \\
\hline Wages and salaries & 8.0 & 8.4 & 7.9 & 7.9 & 7.9 & 7.7 \\
\hline Public service retrenchment & 0.5 & 0.0 & 0.1 & 0.1 & 0.1 & 0.2 \\
\hline Recurrent departmental charges (RDCs) 1/ & 3.6 & 3.2 & 2.7 & 3.5 & 3.6 & 3.4 \\
\hline Arrears clearance & 0.9 & 0.3 & 0.3 & 0.6 & 0.5 & 0.4 \\
\hline Awards and Compensations (Court decisions) & 0.0 & 0.1 & 0.1 & 0.1 & 0.1 & 0.1 \\
\hline Elections \& constitutional review & 0.0 & 0.0 & 0.1 & 0.2 & 0.4 & 0.0 \\
\hline HIPC financed & 0.1 & 0.0 & 0.0 & 0.3 & 0.3 & 0.3 \\
\hline Other RDCs & 2.6 & 2.7 & 2.1 & 2.3 & 2.3 & 2.5 \\
\hline Transfers and pensions & 2.5 & 1.8 & 1.6 & 1.6 & 1.6 & 1.5 \\
\hline Of which: HIPC financed & 0.1 & 0.0 & 0.0 & 0.0 & 0.0 & 0.0 \\
\hline Of which: Settlement of statutory pension arrears & 0.0 & 0.0 & 0.1 & 0.1 & 0.1 & 0.1 \\
\hline Domestic interest & 2.8 & 2.7 & 3.3 & 3.2 & 2.5 & 2.0 \\
\hline External interest 2/ & 1.3 & 1.1 & 0.8 & 0.7 & 0.6 & 0.6 \\
\hline Other current expenditures & 0.6 & 2.2 & 1.6 & 1.2 & 1.1 & 1.0 \\
\hline Non-PRP current expenditures & 0.3 & 2.2 & 1.0 & 0.9 & 0.8 & 0.7 \\
\hline Of which: financial restructuring & 0.0 & 1.0 & 0.5 & 0.4 & 0.3 & 0.3 \\
\hline PRP current expenditures & 0.3 & 0.0 & 0.6 & 0.3 & 0.3 & 0.3 \\
\hline Contingency & 0.2 & 0.0 & 0.0 & 0.1 & 0.1 & 0.1 \\
\hline Capital expenditure & 11.8 & 11.4 & 9.2 & 10.0 & 10.5 & 11.5 \\
\hline Domestically financed & 2.6 & 2.5 & 2.4 & 2.9 & 3.3 & 4.1 \\
\hline Of which: HIPC financed & 0.5 & 1.0 & 1.5 & 2.0 & 2.4 & 3.1 \\
\hline Foreign financed & 9.3 & 8.9 & 6.8 & 7.2 & 7.2 & 7.4 \\
\hline Change in balances and statistical discrepancy $(-=$ overfin. $) 3 /$ & -1.3 & -0.6 & -0.3 & 0.0 & 0.0 & 0.0 \\
\hline Overall balance (cash basis) & -6.3 & -6.6 & -3.4 & -3.2 & -2.4 & -2.4 \\
\hline Overall balance excluding grants & -13.4 & -12.9 & -8.6 & -9.8 & -9.3 & -9.3 \\
\hline Domestic balance & -2.8 & -2.9 & -1.0 & -1.9 & -1.4 & -1.4 \\
\hline Domestic primary balance & -0.1 & -0.2 & 2.4 & 1.3 & 1.0 & 0.6 \\
\hline Financing & 6.3 & 6.6 & 3.4 & 2.7 & 1.7 & 1.4 \\
\hline Domestic 4/ & 2.1 & 5.1 & 2.2 & 1.2 & 0.9 & 0.5 \\
\hline Bank & 0.6 & 4.8 & 1.7 & $\ldots$ & $\ldots$ & $\ldots$ \\
\hline Nonbank & 1.5 & 0.3 & 0.5 & $\ldots$ & $\ldots$ & $\ldots$ \\
\hline External & 4.3 & 1.5 & 1.2 & 1.5 & 0.8 & 0.9 \\
\hline Program loans & 1.8 & 0.2 & 0.7 & 0.8 & 0.6 & 0.5 \\
\hline Project loans & 3.0 & 3.1 & 2.1 & 1.9 & 1.3 & 1.3 \\
\hline Amortization 2/ & -0.5 & -1.8 & -1.7 & -1.2 & -1.1 & -1.0 \\
\hline Financing gap 5/ & 0.0 & 0.0 & 0.0 & 0.6 & 0.7 & 1.0 \\
\hline \multicolumn{7}{|l|}{ Memorandum items: } \\
\hline Priority poverty-reducing spending & 0.9 & 1.0 & 2.1 & 2.6 & 2.9 & 3.7 \\
\hline External budget support & 3.8 & 0.8 & 1.3 & 2.6 & 2.3 & 2.4 \\
\hline Stock of domestic arrears (end period) & 3.7 & 3.6 & 2.6 & 1.6 & 0.8 & 0.3 \\
\hline Stock of domestic debt (end period) 6/ & 21.0 & 20.8 & 20.3 & 17.3 & 15.3 & 14.2 \\
\hline GDP (In billions of kwacha) & 16,260 & 20,520 & 25,578 & 30,444 & 35,340 & 39,333 \\
\hline
\end{tabular}

Sources: Zambian authorities; and Fund staff estimates and projections.

1/ Recurrent Departmental Charges include purchases of goods and service, some allowances and training expenses.

2/ The last Paris Club rescheduling agreement providing debt relief on Cologne flow terms expired at end-March 2003. Zambia is expected to accumulate external arrears on rescheduable debt until a new Paris Club agreement on Cologne flow terms is in place, following the approval of the PRGF arrangement. Once the completion point under the HIPC Initiative is reached, the Paris Club is expected to provide debt relief on Cologne stock terms.

3/ Payments to RAMCOZ employees for retrenchment (K 70 billion) released in Q4 2003 were cashed in Q1 2004.

4/ Until 2003 at face value. From 2004 at cost value. Excludes bonds issued in 2001 in favor of the Bank of Zambia (K 1,646 billion) and in 2002 in favor of the Zambia National Commercial Bank (K 248 billion).

5/ The projected financing gaps in 2005-07 are expected to be covered by additional support from donors.

6/ At cost value. Include bonds issued in 2001 in favor of BoZ (K 1,646 bn) and in 2002 in favor of the Zambia National Commercial Bank (K 248 billion). 
Table 6: Zambia: Balance of Payments, 2000-07 (In millions of U.S. dollars, unless otherwise indicated)

\begin{tabular}{|c|c|c|c|c|c|c|c|c|}
\hline & $\begin{array}{r}2000 \\
\text { Est. }\end{array}$ & $\begin{array}{r}2001 \\
\text { Est. }\end{array}$ & $\begin{array}{r}2002 \\
\text { Est. }\end{array}$ & $\begin{array}{r}2003 \\
\text { Est. }\end{array}$ & $\begin{array}{l}2004 \\
\text { Prog. }\end{array}$ & $\begin{array}{l}2005 \\
\text { Proj. }\end{array}$ & $\begin{array}{r}2006 \\
\text { Proj. }\end{array}$ & $\begin{array}{r}2007 \\
\text { Proj. }\end{array}$ \\
\hline Current account balance 1/ & -622 & -758 & -652 & -618 & -589 & -623 & -657 & -720 \\
\hline Trade balance on goods and nonfactor services & -446 & -570 & -504 & -468 & -433 & -454 & -430 & -466 \\
\hline Merchandise trade balance & -221 & -342 & -259 & -230 & -166 & -168 & -132 & -166 \\
\hline Exports, f.o.b. & 746 & 884 & 916 & 1,134 & 1,403 & 1,585 & 1,718 & 1,735 \\
\hline Metal sector & 497 & 590 & 560 & 729 & 949 & 1,088 & 1,174 & 1,139 \\
\hline Nonmetal & 249 & 295 & 357 & 405 & 454 & 498 & 545 & 596 \\
\hline Imports, f.o.b. & -978 & $-1,253$ & $-1,204$ & $-1,393$ & $-1,599$ & $-1,785$ & $-1,884$ & $-1,936$ \\
\hline Goods procured by airlines & 11 & 27 & 28 & 29 & 30 & 32 & 34 & 35 \\
\hline Services, nonfactor (net) & -225 & -228 & -245 & -238 & -267 & -286 & -298 & -301 \\
\hline Income (net) & -158 & -168 & -155 & -148 & -132 & -138 & -192 & -215 \\
\hline Of which: Official interest payments & -155 & -144 & -137 & -131 & -120 & -109 & -101 & -97 \\
\hline Current transfers (net) & -18 & -20 & 7 & -2 & -24 & -31 & -36 & -38 \\
\hline Capital and financial accounts & 202 & 466 & 286 & 377 & 306 & 406 & 432 & 515 \\
\hline Project grants & 153 & 222 & 236 & 240 & 246 & 284 & 335 & 367 \\
\hline Official loan disbursement (net) & -140 & -96 & -122 & -141 & -106 & -79 & -62 & -64 \\
\hline Disbursement & 93 & 136 & 111 & 101 & 110 & 99 & 76 & 79 \\
\hline Amortization (-) & -233 & -233 & -234 & -242 & -216 & -178 & -138 & -143 \\
\hline Change in NFA of commercial banks (-increase) & -89 & 40 & -5 & 44 & -5 & -5 & -5 & -5 \\
\hline Private capital (net) & 278 & 301 & 178 & 233 & 171 & 206 & 164 & 216 \\
\hline Errors and omissions, short-term capital & 4 & -107 & -17 & -80 & 0 & 0 & 0 & 0 \\
\hline Overall balance & -416 & -399 & -383 & -321 & -283 & -216 & -225 & -205 \\
\hline Financing & 416 & 399 & 383 & 321 & 283 & 186 & 184 & 145 \\
\hline Change in net int. reserves of BoZ (-increase) & -49 & -124 & -225 & -164 & 12 & -323 & -41 & -81 \\
\hline Gross official reserves of BoZ (-increase) & -68 & 0 & -169 & 87 & 24 & -104 & -57 & -58 \\
\hline IMF (net) & 26 & -119 & -50 & -244 & -5 & -213 & 17 & -23 \\
\hline Disbursements & 26 & 94 & 173 & 0 & 236 & 32 & 32 & 16 \\
\hline Repayments & 0 & -213 & -222 & -244 & -241 & -245 & -15 & -39 \\
\hline Debt relief & 217 & 436 & 437 & 391 & 276 & 431 & 167 & 170 \\
\hline Non-HIPC 2/ & 217 & 170 & 171 & 154 & 120 & 67 & 19 & 21 \\
\hline HIPC, including IMF $3 /$ & $\ldots$ & 266 & 266 & 237 & 156 & 333 & 118 & 120 \\
\hline Of which : IMF & $\ldots$ & 150 & 153 & 171 & 0 & 220 & 0 & 0 \\
\hline Of which : Paris Club 4/ & $\ldots$ & 65 & 64 & 16 & 100 & 53 & 55 & 57 \\
\hline Possible additional debt relief after HIPC CP 6 / & $\ldots$ & $\ldots$ & $\ldots$ & $\ldots$ & $\ldots$ & 31 & 30 & 30 \\
\hline Other debt related items 5 / & 42 & -19 & 21 & -10 & -14 & 0 & 0 & 0 \\
\hline Net change in arrears (+ increase) $4 /$ & -10 & 31 & 12 & 48 & -60 & 0 & 0 & 0 \\
\hline Program support & 185 & 75 & 138 & 55 & 69 & 78 & 58 & 56 \\
\hline Grants & 32 & 31 & 69 & 45 & 33 & 37 & 25 & 23 \\
\hline Loans & 154 & 44 & 69 & 10 & 36 & 41 & 33 & 33 \\
\hline Financing Gap (+ deficit) & 0 & 0 & 0 & 0 & 0 & 30 & 40 & 60 \\
\hline \multicolumn{9}{|l|}{ Memorandum items: } \\
\hline Current acc't bal. excl. grants (percent of GDP) & -19.2 & -20.8 & -17.3 & -14.3 & -11.4 & -11.6 & -11.5 & -11.9 \\
\hline Current acc't bal. incl. grants (US\$m) 6/ & -369 & -394 & -246 & -241 & -238 & -207 & -212 & -232 \\
\hline Current acc't bal. incl. grants (percent of GDP) 7/ & -11.4 & -10.8 & -6.5 & -5.6 & -4.6 & -3.9 & -3.7 & -3.8 \\
\hline Merchandise trade balance (percent of GDP) & -6.8 & -9.4 & -6.9 & -5.3 & -3.2 & -3.1 & -2.3 & -2.7 \\
\hline Terms of trade (percentage change) & -4.5 & -2.1 & -7.0 & 5.0 & 10.7 & -0.2 & 0.7 & -0.1 \\
\hline Copper volume (thousands of metric tons) & 234 & 297 & 330 & 353 & 382 & 469 & 538 & 563 \\
\hline Copper price (U.S. dollars per pound) & 0.82 & 0.77 & 0.70 & 0.78 & 0.96 & 0.92 & 0.88 & 0.86 \\
\hline Gross official reserves 8 / & 114 & 114 & 283 & 197 & 173 & 277 & 334 & 392 \\
\hline (in months of imports) & 1.0 & 0.9 & 2.2 & 1.3 & 1.0 & 1.5 & 1.7 & 1.9 \\
\hline Official debt service, cash payments 9/ & 139 & 142 & 123 & 187 & 376 & 100 & 87 & 109 \\
\hline (in percent of exports) & 15.9 & 13.5 & 11.4 & 14.1 & 23.4 & 5.5 & 4.4 & 5.5 \\
\hline Official budget debt service, cash payments & 130 & 70 & 50 & 108 & 129 & 70 & 68 & 65 \\
\hline Net present value of debt, percent of exports 10 / & 213 & 208 & 205 & 181 & 157 & 129 & 116 & 110 \\
\hline
\end{tabular}

Sources: Bank of Zambia (BoZ); and Fund staff estimates and projections.

1/ Excluding grants and debt relief on interest.

2/ Indicates debt relief that would have been available under the traditional mechanism, relative to 1999 Paris Club rescheduling, comparable treatment from non-Paris Club bilaterals and the 1997 restructuring of Camdex claim on the BoZ

3/ It is assumed that Zambia will reach the HIPC completion point in the first half of 2005.

4/ The last Paris Club rescheduling agreement providing debt relief on Cologne flow terms expired at end-March 2003. Zambia is expected to accumulate external arrears on rescheduable debt until a new Paris Club agreement on Cologne flow terms is in place, following the approval of the PRGF arrangement. Once the completion point under the HIPC Initiative is reached, the Paris Club is expected to provide debt relief on Cologne stock terms. 5/ Reconciliation of scheduled debt service after scheduled debt relief with actual cash payments. Item includes overpayments, refunds, debt service carryover, currency revaluations and additional debt relief.

6/ Additional debt relief is expected from Paris Club creditors once Zambia reaches the HIPC completion point.

7/ Includes project and program grants, as well as debt relief on interest payments. Also includes grants assumed to partially close the financing gap.

8/ Reserves at current exchange rates. Includes balances in the special Bank for International Settlements.

8/ According to Table 14 (revised) in Zambia's decision point document,November 20, 2000.

9/ Includes debt service on new PRGF disbursements as well as loans assumed to help close the financing gap. Also assumes additional debt relief beyond HIPC from 2005.

10/ Includes possible additional debt relief beyond the HIPC Initiative. 
Table 7. Zambia: External Financing, 2000-07 (In millions of U.S. dollars)

\begin{tabular}{|c|c|c|c|c|c|c|c|c|}
\hline & $\begin{array}{r}2000 \\
\text { Est. } \\
\end{array}$ & $\begin{array}{r}2001 \\
\text { Est. }\end{array}$ & $\begin{array}{r}2002 \\
\text { Est. }\end{array}$ & $\begin{array}{r}2003 \\
\text { Est. }\end{array}$ & $\begin{array}{c}2004 \\
\text { Prog. }\end{array}$ & $\begin{array}{l}2005 \\
\text { Proj. }\end{array}$ & $\begin{array}{l}2006 \\
\text { Proj. } \\
\end{array}$ & $\begin{array}{l}2007 \\
\text { Proj. }\end{array}$ \\
\hline Current account deficit (excl. official transfers and interest) & -467 & -614 & -543 & -507 & -469 & -514 & -556 & -622 \\
\hline Change in n.f.a. of commercial banks & -89 & 40 & -5 & 44 & -5 & -5 & -5 & -5 \\
\hline Private capital (net) & 278 & 301 & 178 & 233 & 171 & 206 & 164 & 216 \\
\hline Gross reserves (-, increase) & -68 & 0 & -169 & 87 & 24 & -104 & -57 & -58 \\
\hline BoZ liabilities & -7 & -5 & -6 & -6 & -6 & -6 & 0 & 0 \\
\hline Other foreign assets of the $\mathrm{BoZ}$ & $30 \ldots$ & $\ldots$ & $\ldots$ & $\ldots$ & $\ldots$ & $\ldots$ & .. & \\
\hline Debt service, scheduled $/ 3$ & -388 & -590 & -593 & -616 & -578 & -531 & -254 & -279 \\
\hline Interest & -155 & -144 & -137 & -131 & -120 & -109 & -101 & -97 \\
\hline Multilaterals & -39 & -37 & -31 & -33 & -33 & -31 & -29 & -30 \\
\hline Of which: IMF & -9 & -8 & -3 & -6 & -6 & -5 & -4 & -5 \\
\hline Bilaterals & -116 & -107 & -105 & -98 & -88 & -77 & -72 & -67 \\
\hline Of which: Paris Club & -114 & -105 & -104 & -97 & -88 & -77 & -72 & -67 \\
\hline Amortization & -233 & -446 & -456 & -486 & -458 & -422 & -153 & -181 \\
\hline Multilaterals & -41 & -260 & -270 & -295 & -292 & -299 & -74 & -98 \\
\hline Of which: IMF & 0 & -213 & -222 & -244 & -241 & -245 & -15 & -39 \\
\hline Bilaterals & -192 & -186 & -186 & -191 & -173 & -123 & -78 & -83 \\
\hline Of which: Paris Club & -173 & -167 & -169 & -180 & -162 & -116 & -74 & -80 \\
\hline Other debt related items & 42 & -19 & 21 & -10 & -14 & 0 & 0 & 0 \\
\hline Accumulation of arrears (+increase) & -10 & 31 & 12 & 48 & -60 & 0 & 0 & 0 \\
\hline Financing gap before debt relief and donor disbursements & -679 & -856 & -1105 & -728 & -937 & -954 & -708 & -748 \\
\hline Debt relief & 217 & 436 & 437 & 391 & 276 & 431 & 167 & 170 \\
\hline Before HIPC-Paris Club $/ 4$ & 217 & 170 & 171 & 154 & 120 & 67 & 19 & 21 \\
\hline HIPC debt relief $/ 5$ & $\ldots$ & 266 & 266 & 237 & 156 & 333 & 118 & 120 \\
\hline Of which: IMF & $\ldots$ & 150 & 153 & 171 & 0 & 220 & 0 & 0 \\
\hline Of which: Paris Club & $\ldots$ & 65 & 64 & 16 & 100 & 53 & 55 & 57 \\
\hline Possible additional debt relief after HIPC CP /6 & $\ldots$ & $\cdots$ & $\ldots$ & $\ldots$ & $\cdots$ & 31 & 30 & 30 \\
\hline Gross official assistance & 457 & 527 & 685 & 416 & 661 & 493 & 500 & 518 \\
\hline Official creditors, excl. IMF & 431 & 433 & 512 & 416 & 425 & 461 & 468 & 502 \\
\hline Budgetary support & 185 & 75 & 138 & 55 & 69 & 78 & 58 & 56 \\
\hline World Bank /1 & 140 & 44 & 56 & 20 & 34 & 20 & 20 & 20 \\
\hline AfDB & 13 & 0 & 13 & 0 & 9 & 21 & 13 & 13 \\
\hline EU/Other $/ 2$ & 32 & 31 & 69 & 35 & 26 & 37 & 25 & 23 \\
\hline Project financing & 246 & 358 & 347 & 341 & 356 & 383 & 411 & 446 \\
\hline Grants & 153 & 222 & 236 & 240 & 246 & 284 & 335 & 367 \\
\hline Loans & 93 & 136 & 111 & 101 & 110 & 99 & 76 & 79 \\
\hline Of which: World Bank & 66 & 119 & 90 & 77 & 80 & 79 & 61 & 63 \\
\hline Commodity support & 0 & 0 & 27 & 20 & 0 & 0 & 0 & 0 \\
\hline IMF (PRGF) & 26 & 94 & 173 & 0 & 236 & 32 & 32 & 16 \\
\hline Errors and omissions & 4 & -107 & -17 & -80 & $\mathbf{0}$ & $\mathbf{0}$ & $\mathbf{0}$ & $\mathbf{0}$ \\
\hline Financing gap (+ surplus/- deficit) $/ 7$ & $\mathbf{0}$ & $\mathbf{0}$ & $\mathbf{0}$ & $\mathbf{0}$ & $\mathbf{0}$ & -30 & -40 & -60 \\
\hline \multicolumn{9}{|l|}{ Memorandum items: } \\
\hline Nominal GDP, US\$ millions & 3,239 & 3,640 & 3,776 & 4,314 & 5,157 & 5,371 & 5,695 & 6,063 \\
\hline Official debt service, cash payments, incl IMF & -139 & -142 & -123 & -187 & -376 & -100 & -86 & -108 \\
\hline Official debt service, cash payments, excl IMF & -130 & -70 & -50 & -108 & -129 & -70 & -68 & -65 \\
\hline Of which: Paris Club & -38 & -26 & -5 & -69 & -104 & -42 & -42 & -40 \\
\hline Net resource inflows, incl. IMF & 318 & 385 & 563 & 230 & 285 & 392 & 414 & 409 \\
\hline Percent of GDP & 9.8 & 10.6 & 14.9 & 5.3 & 5.5 & 7.9 & 8.0 & 7.7 \\
\hline Net resource inflows, excl. IMF & 301 & 363 & 462 & 308 & 296 & 391 & 401 & 437 \\
\hline Percent of GDP & 9.3 & 10.0 & 12.2 & 7.1 & 5.7 & 7.3 & 7.0 & 7.2 \\
\hline Gross official external reserves, eop & 114 & 114 & 283 & 197 & 173 & 277 & 334 & 392 \\
\hline Months of imports & 1.0 & 0.9 & 2.2 & 1.3 & 1.0 & 1.5 & 1.7 & 1.9 \\
\hline Percent of annual official debt service & 82 & 80 & 231 & 105 & 46 & 275 & 385 & 361 \\
\hline
\end{tabular}

Sources: Bank of Zambia (BoZ); and IMF staff estimates and projections.

$1 /$ Assumes that Zambia moves to and remains on the base case for CAS.

2/ Assumes that disbursements under the EU variable tranche will be about 50 percent of funds allocated.

3/ Scheduled, before debt relief. Drawn from 2000 decision point document adjusted for new loans.

4/ Indicates debt relief that would have been available under the traditional mechanism, relative to 1999 Paris Club rescheduling, comparable treatment from non-Paris Club bilaterals and the 1997 restructuring of Camdex claim on the BoZ.

5/ The last Paris Club rescheduling agreement providing debt relief on Cologne flow terms expired at end-March 2003. Zambia is expected to accumulate external arrears on rescheduable debt until a new Paris Club agreement on Cologne flow terms is in place, following the approval of the PRGF arrangement. Once the completion point under the HIPC Initiative is reached, the Paris Club is expected to provide debt relief on Cologne stock terms.

6/ Possible additional debt relief above and beyond HIPC assistance from bilateral creditors following the HIPC completion point.

7/ Possible additional financing from a higher allocation under the WB CAS, stronger performance and disbursements from the EU, and from other donors. 
Table 8. Zambia: Assets and liabilities of the Bank of Zambia, 2000-04

(In billions of kwacha, unless otherwise indicated)

\begin{tabular}{|c|c|c|c|c|c|c|}
\hline & \multirow{2}{*}{$\begin{array}{c}2000 \\
\text { Act. }\end{array}$} & \multirow{2}{*}{$\begin{array}{c}2001 \\
\text { Act. }\end{array}$} & \multirow{2}{*}{$\begin{array}{r}2002 \\
\text { Act. }\end{array}$} & \multicolumn{2}{|c|}{2003} & \multirow{2}{*}{$\begin{array}{l}2004 \\
\text { Prog. }\end{array}$} \\
\hline & & & & Act. & $\overline{\text { Base 1/ }}$ & \\
\hline Net foreign assets & $-2,440$ & $-3,705$ & $-1,954$ & $-2,377$ & $-2,788$ & $-2,833$ \\
\hline Assets & 772 & 588 & 1,692 & 892 & 956 & 857 \\
\hline Liabilities & $-3,212$ & $-4,294$ & $-3,646$ & $-3,269$ & $-3,744$ & $-3,690$ \\
\hline Of which: IMF (net) & $-3,155$ & $-4,229$ & $-3,603$ & $-3,242$ & $-3,715$ & $-3,684$ \\
\hline Net domestic assets & 2,996 & 4,513 & 3,158 & 3,796 & 4,207 & 4,334 \\
\hline Net domestic credit & 424 & 858 & -189 & -476 & -615 & -518 \\
\hline Net claims on government & 638 & 1,165 & 1,128 & 1,090 & 1,090 & 1,120 \\
\hline Claims on government & 1,100 & 1,888 & 1,865 & 1,973 & $\ldots$ & $\ldots$ \\
\hline Government deposits & -463 & -723 & -737 & -883 & $\ldots$ & $\ldots$ \\
\hline HIPC account (IMF) & -401 & -622 & $-1,704$ & $-1,929$ & $-2,067$ & $-2,067$ \\
\hline Claims on nongovernment & 187 & 315 & 387 & 363 & 363 & 429 \\
\hline Of which: claims on banks & 82 & 77 & 112 & 262 & $\ldots$ & $\ldots$ \\
\hline Other items (net) & 2,572 & 3,655 & 3,347 & 4,272 & 4,822 & 4,734 \\
\hline Open market operations & $\ldots$ & $\ldots$ & $\ldots$ & 0 & 0 & 118 \\
\hline Reserve money & 556 & 808 & 1,205 & 1,419 & 1,419 & 1,501 \\
\hline Currency in circulation & 331 & 432 & 479 & 670 & $\ldots$ & $\ldots$ \\
\hline Required reserves (kwacha deposits) & 88 & 182 & 264 & 286 & $\ldots$ & ... \\
\hline Required reserves (foreign exchange deposits) & 101 & 138 & 234 & 224 & $\ldots$ & $\ldots$ \\
\hline Dollar denominated & 0 & 0 & 86 & 224 & $\ldots$ & $\ldots$ \\
\hline Kwacha denominated & 101 & 138 & 148 & 0 & $\ldots$ & $\ldots$ \\
\hline Current accounts & 34 & 52 & 222 & 233 & $\ldots$ & $\ldots$ \\
\hline Nongovernment deposits & 2 & 4 & 6 & 6 & .. & ... \\
\hline \multicolumn{7}{|l|}{ Memorandum items: } \\
\hline Multiplier (broad money/reserve money) & 3.8 & 3.4 & 3.0 & 3.1 & $\ldots$ & 3.5 \\
\hline Percent change from end of previous year & $\ldots$ & $\ldots$ & $\ldots$ & 17.8 & $\ldots$ & 5.7 \\
\hline
\end{tabular}

Sources: Zambian authorities; and Fund staff estimates and projections.

1/ The 2003 base has been adjusted to reflect the recording of government securities at cost rather than at face value. 
Table 9. Zambia: Monetary Survey, 2000-04

\begin{tabular}{|c|c|c|c|c|c|c|}
\hline & 2000 & 2001 & 2002 & \multicolumn{2}{|c|}{2003} & \multirow{2}{*}{$\begin{array}{l}2004 \\
\text { Prog. }\end{array}$} \\
\hline & Act. & Act. & Act. & Act. & Base 1/ & \\
\hline & \multicolumn{6}{|c|}{ (In billions of kwacha) } \\
\hline Net foreign assets & $-1,512$ & $-2,843$ & -957 & $-1,454$ & $-1,799$ & $-1,798$ \\
\hline Bank of Zambia & $-2,440$ & $-3,705$ & $-1,954$ & $-2,377$ & $-2,788$ & $-2,833$ \\
\hline Assets & 772 & 588 & 1,692 & 892 & 956 & 857 \\
\hline Liabilities & $-3,212$ & $-4,294$ & $-3,646$ & $-3,269$ & $-3,744$ & $-3,690$ \\
\hline Commercial banks & 927 & 863 & 997 & 922 & 988 & 1,035 \\
\hline Assets & 996 & 956 & 1,081 & 1,030 & 1,104 & $\ldots$ \\
\hline Liabilities & -68 & -94 & -84 & -108 & -116 & $\ldots$ \\
\hline Net domestic assets & 3,998 & 5,596 & 4,577 & 5,922 & 6,267 & 7,077 \\
\hline Net domestic credit & 1,772 & 2,593 & 1,784 & 2,323 & 1,952 & 2,791 \\
\hline Net claims on government & 952 & 1,848 & 1,932 & 2,746 & 2,473 & 2,907 \\
\hline Claims on government & 1,460 & 2,666 & 2,781 & 3,830 & 3,558 & $\ldots$ \\
\hline Government deposits & -508 & -818 & -849 & $-1,085$ & $-1,085$ & $\ldots$ \\
\hline HIPC account (IMF) & -401 & -643 & $-1,704$ & $-1,929$ & $-2,067$ & $-2,067$ \\
\hline Claims on nongovernment & 1,221 & 1,388 & 1,556 & 1,506 & 1,545 & 1,951 \\
\hline Claims on private sector & 862 & 946 & 1,019 & 1,390 & 1,429 & 1,803 \\
\hline Claims on public enterprises $2 /$ & 359 & 442 & 537 & 116 & 116 & 148 \\
\hline Other items (net) & 2,226 & 3,003 & 2,793 & 3,599 & 4,316 & 4,286 \\
\hline Broad money & 2,486 & 2,754 & 3,620 & 4,468 & 4,468 & 5,279 \\
\hline Narrow money & 761 & 1,015 & 1,323 & 1,696 & 1,696 & $\ldots$ \\
\hline Quasi money & 1,725 & 1,738 & 2,296 & 2,772 & 2,772 & $\ldots$ \\
\hline Foreign exchange deposits & 1,171 & 1,045 & 1,429 & 1,619 & 1,619 & $\ldots$ \\
\hline \multirow[t]{2}{*}{ Other } & 554 & 693 & 867 & 1,153 & 1,153 & $\ldots$ \\
\hline & \multicolumn{5}{|c|}{$\begin{array}{c}\text { (Change in percent of beginning-of-year broad money, } \\
\text { unless otherwise indicated) }\end{array}$} & \\
\hline Net foreign assets & 63.8 & -53.5 & 68.5 & -9.0 & $\ldots$ & 0.0 \\
\hline Net domestic assets & 10.3 & 64.3 & -37.0 & 32.5 & $\ldots$ & 18.1 \\
\hline Net domestic credit & 18.7 & 33.0 & -29.4 & 36.6 & $\ldots$ & 18.8 \\
\hline Net claims on government & 18.1 & 36.0 & 3.1 & 27.0 & $\ldots$ & 9.7 \\
\hline Claims on nongovernment & 28.6 & 6.7 & 6.1 & 9.6 & $\ldots$ & 9.1 \\
\hline Claims on private sector & 21.5 & 3.4 & 2.7 & 9.0 & $\ldots$ & 8.4 \\
\hline Claims on public enterprises & 7.1 & 3.3 & 3.5 & 0.6 & $\ldots$ & 0.7 \\
\hline Other items (net) & -8.4 & 31.3 & -7.6 & -4.1 & $\ldots$ & -0.7 \\
\hline Broad money & 74.1 & 10.8 & 31.5 & 23.4 & $\cdots$ & 18.1 \\
\hline
\end{tabular}

Sources: Zambian authorities; and Fund staff estimates and projections.

1/ The 2003 base has been adjusted to reflect the recording of government securities at cost rather than at face value. 2/ In 2002, includes the bond issued to the Zambia National Commercial Bank (ZNCB) (K 250 billion) to cover liabilities of the Zambia National Oil Company (ZNOC) and Roan Antelope Mining Company. 
Table 10. Zambia: Schedule of Disbursements Under the Proposed PRGF Arrangement, 2004-07

\begin{tabular}{|c|c|c|c|}
\hline \multicolumn{2}{|c|}{ Amount } & \multirow{2}{*}{$\begin{array}{l}\text { Availability } \\
\text { Date }\end{array}$} & \multirow[t]{2}{*}{ Conditions Necessary for Disbursement } \\
\hline $\begin{array}{l}\text { (In millions of } \\
\text { SDRs) }\end{array}$ & $\begin{array}{c}\text { (In percent } \\
\text { of quota) }\end{array}$ & & \\
\hline 82.5356 & 16.88 & June 14, 2004 & $\begin{array}{l}\text { Tentative date for Board approval of the three-year arrangement } \\
\text { and endorsement of the annual program. }\end{array}$ \\
\hline 82.5356 & 16.88 & December 13, 2004 & $\begin{array}{l}\text { Observance of the September 30, } 2004 \text { performance criteria } \\
\text { and completion of the first review. }\end{array}$ \\
\hline 5.5024 & 1.13 & March 15, 2005 & $\begin{array}{l}\text { Observance of the December 31, } 2004 \text { performance criteria. } \\
\text { and completion of the second review. }\end{array}$ \\
\hline 5.5024 & 1.13 & June 14, 2005 & Observance of the March 31, 2005 performance criteria \\
\hline 5.5024 & 1.13 & September 13, 2005 & $\begin{array}{l}\text { Observance of the June } 30,2005 \text { performance criteria. } \\
\text { and completion of the third review. }\end{array}$ \\
\hline 5.5024 & 1.13 & December 13, 2005 & Observance of the September 30, 2005 performance criteria \\
\hline 5.5024 & 1.13 & March 15, 2006 & $\begin{array}{l}\text { Observance of the December } 31,2005 \text { performance criteria. } \\
\text { and completion of the fourth review. }\end{array}$ \\
\hline 5.5024 & 1.13 & June 14, 2006 & Observance of the March 31, 2006 performance criteria \\
\hline 5.5024 & 1.13 & September 13, 2006 & $\begin{array}{l}\text { Observance of the June } 30,2006 \text { performance criteria. } \\
\text { and completion of the fifth review. }\end{array}$ \\
\hline 5.5024 & 1.13 & December 13, 2006 & Observance of the September 30, 2006 performance criteria \\
\hline 5.5024 & 1.13 & March 14, 2007 & $\begin{array}{l}\text { Observance of the December } 31,2006 \text { performance criteria. } \\
\text { and completion of the sixth review. }\end{array}$ \\
\hline 5.5024 & 1.13 & May 31, 2007 & Observance of the March 31,2007 performance criteria \\
\hline
\end{tabular}




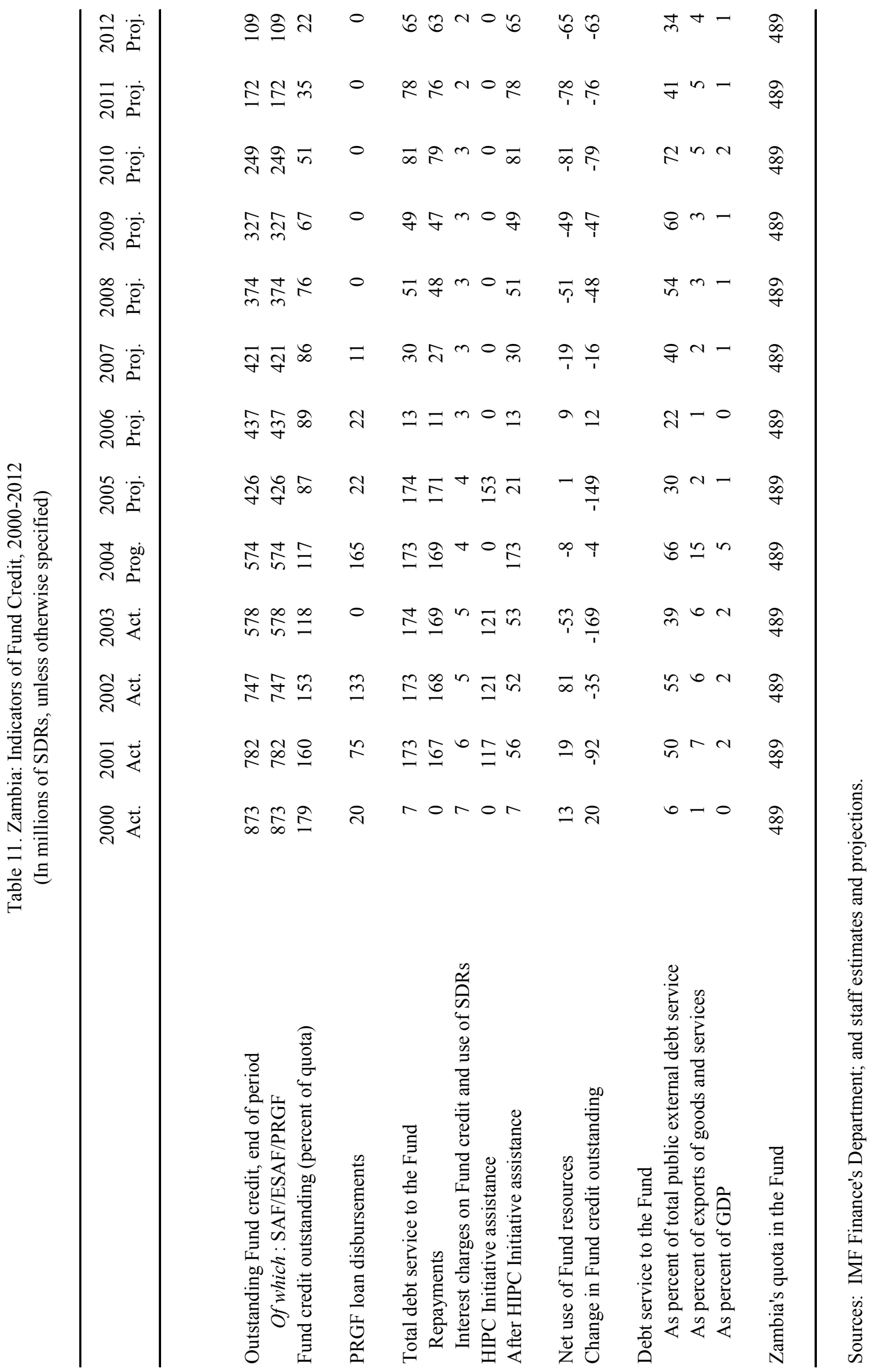




\author{
Ms. Krueger \\ The Acting Managing Director \\ International Monetary Fund \\ Washington, D.C.
}

Dear Ms. Krueger:

In March, the Government of Zambia requested that the staff-monitored program (SMP) covering the second half of 2003 be extended through end-June 2004. The attached Memorandum of Economic and Financial Policies (MEFP) reviews progress in implementing the SMP and describes our medium-term adjustment strategy for the period 2004-07. In line with the agenda established in the PRSP, this strategy aims at accelerating economic growth and reducing poverty by, inter alia, implementing sustainable fiscal and monetary policies, and structural reforms to support fiscal adjustment and a reorientation of spending towards poverty reduction, improve the environment for private sector development and strengthen governance. In order to support the implementation of these medium-term reforms, the Government of Zambia requests a new arrangement under the Poverty Reduction and Growth Facility (PRGF) in a total amount equivalent to SDR 220.095 million (45 percent of quota).

Successful implementation of policies supported by the PRGF arrangement will be essential to allow Zambia to reach the Completion Point under the enhanced HIPC Initiative. Attaining the Completion Point will be key to reducing Zambia's external debt to sustainable levels and will also lower debt service payments to manageable levels, so as to release resources to poverty-reducing expenditures.

The Government of Zambia believes that the policies set forth in the attached MEFP are adequate to achieve the objectives of its program, but it will take any further measures that may become appropriate for this purpose. Zambia will consult with the Fund on the adoption of these measures and in advance of revisions to policies contained in the MEFP, in accordance with the Fund's policies on such consultation.

The Government of Zambia authorizes the IMF to make this letter and attached memoranda available to the public, including through the placement of these documents on the IMF website, subject to the removal of market-sensitive information, following the IMF Executive Board approval of the requested arrangement.

Yours sincerely,

$$
\text { /s/ }
$$

Hon. Ng'andu Peter Magande, MP

Minister of Finance and National Planning 


\section{ZAMBIA \\ Memorandum of Economic and Financial Policies July 2004 to June 2007}

\section{Performance Under The Extended Staff-Monitored Program}

1. All the key quantitative targets for end-March 2004 under the extended SMP were met. These included: the ceilings on net domestic assets of the Bank of Zambia (BoZ) and net domestic financing of the central government, which were met by wide margins; the floor on gross international reserves of the BoZ; the ceilings on nonconcessional external debt and on concessional borrowing by the Zambia Electricity Supply Corporation (ZESCO), collateralized or guaranteed by the Government of Zambia; and the floor on cumulative deposits into the HIPC Initiative Account No. 49 at the BoZ to finance poverty-reducing programs. The target on the wage bill was also met, even after taking into account the accumulation of arrears toward government employees (Table 1).

2. Through end-April 2004, all the structural benchmarks were observed, with the exception of the benchmarks on preparing an action plan to deal with the insolvent Non-Bank Financial Institutions (NBFIs). and on awarding a contract for the procurement of hardware and software for an Integrated Financial Management and Information System (IFMIS). The latter was delayed, while awaiting a "no objection" from the World Bank (Table 2). The preparation of an action plan to deal with the insolvent NBFIs has been delayed as the Government sought additional technical assistance to deal with these difficult issues. All continuous benchmarks were also observed.

\section{Recent Economic Developments}

3. In 2003, Zambia's economic performance continued to improve. Real GDP is now estimated to have increased by 5.1 percent, bringing the average annual growth over the past four years to 4.2 percent. Preliminary indications from the mining sector, and from the continued strong growth in non-traditional exports, suggest that per capita income in 2004 will increase for the fifth year in a row. The 12-month inflation rate, at 17.2 percent in December 2003, was the lowest in two decades. However, the rate of inflation edged up to 17.6 percent in March 2004, marginally above the SMP target of 17.4 percent, largely on account of higher food prices in the months before the maize harvest.

4. Economic performance in $\mathbf{2 0 0 3}$ was aided by some favorable exogenous developments, including the easing of drought conditions on agriculture and significantly higher copper prices, which offset some of the potential negative impact from the large budgetary overruns. The overall fiscal deficit (after grants) and net domestic financing in 2003 exceeded their targets under the SMP (July-December 2003) by 1.5 percent of GDP and 2 percent of GDP, respectively. These overruns mainly reflected unbudgeted security-related expenditures and payments of retrenchment benefits and wage arrears to workers in the Luanshya mine, to facilitate its sale to a strategic equity partner. 
Expenditures on poverty-reducing programs fell short of the budgeted levels, and domestic arrears continued to accumulate, although at a much reduced rate.

\section{In the first three months of 2004, however, fiscal performance improved} significantly. While revenues were in line with the SMP targets through end-March, expenditures were below the programmed amounts and, as a result, notwithstanding a significant shortfall in net external budgetary support, the adjusted target on net domestic financing was met by a comfortable margin. The monthly wage bill—including housing allowances - was in line with the SMP target. Cumulative funding for poverty-reducing programs was also in line with the SMP target, but actual expenditures on these programs again fell short of budgeted levels, pending approval of the 2004 budget by Parliament.

\section{In 2003, broad money expanded by more than programmed, mainly reflecting} the substantially higher net foreign assets of the banking system. Also, in October 2003, the BoZ loosened monetary policy by lowering the cash legal reserve requirement from 17.5 percent to 14 percent, to provide banks with liquidity for lending to the agricultural sector. Together, these factors resulted in excess liquidity in the banking system, which caused Treasury bill interest rates to fall from a range of 30-35 percent for most of the year to around 20 percent at end-December 2003. During the first three months of 2004, broad money grew by 3.8 percent, which was below the program target. However, excess bank reserves at the BoZ have persisted and, by end-March 2004, nominal interest rates on Treasury bills had fallen below 10 percent, becoming negative in real terms. The commercial banks' overnight lending rates were also in the low single digits. In contrast to developments in the Treasury bill market, commercial banks' weighted lending base rates have declined only gradually from about 37 percent in the last quarter of 2003 to 31.8 percent in March 2004.

7. External developments in 2003 were favorable, as exports were boosted by higher copper prices and further strong growth in nontraditional exports. With total exports growing by an estimated 24 percent, compared with a 16 percent increase in total imports, the external current account deficit, including grants, narrowed by almost 1 percent of GDP to 5.6 percent of GDP in 2003. During the first quarter of 2004, these favorable developments continued; copper prices increased sharply, and non-traditional exports rose by over 40 percent from the same period a year earlier, in part reflecting a substantial increase in tobacco exports. In the interbank foreign exchange market, the kwacha was stable against the U.S. dollar, but depreciated against the euro and the rand. In real effective terms, the kwacha is estimated to have depreciated by 3.3 percent in the 12 months to January 2004.

8. Progress in implementing structural reforms during 2003 was mixed. The BoZ introduced the interbank foreign exchange market, and the Government formulated a medium-term expenditure framework (MTEF) in the preparation of the 2004 budget. However, the impact of steps to strengthen the control of expenditure commitments was undermined by slippages in expenditure policies. To strengthen monitoring of the wage bill, the Ministry of Finance and National Planning (MoFNP) has issued an instruction introducing the tracking of all payments related to housing allowance for civil service employees which will allow the tracking and classifying under personal emoluments of all 
the payments related to housing allowance. The MoFNP has also set up a unit dedicated to monitoring and reporting, on a monthly basis, all payments to civil service employees as specified in the attached technical memorandum of understanding (TMU) (paragraph 27). The government has also approved a requirement that the Minister of Finance and National Planning should submit to the Cabinet an analysis of the short and medium-term budget costs of any agreement with government employees before it is finalized.

\section{As noted above, the implementation of structural reforms improved in early} 2004, with virtually all the structural benchmarks under the SMP observed. In addition, there has been progress in implementing the plan, agreed with the staff of the World Bank and IMF, to commercialize ZESCO. Discussions with the first preferred bidder for the partial sale of Zambia National Commercial Bank (ZNCB) are continuing; however, in order to expedite the sale, the Zambia Privatization Agency (ZPA) has initiated parallel discussions with the second preferred bidder. The Government completed the sale of the Luanshya mine, formerly owned by the Roan Antelope Mining Company of Zambia, in early 2004, and has made substantial progress in seeking a new strategic equity investor for the Konkola Copper Mines (KCM). In the area of public expenditure management, an activity-based budget was introduced for preparation, execution, and reporting of fiscal operations in 2004 . However, the need to align the reporting system to the activity-based budget classification delayed the delivery of the monthly expenditure reports.

10. The Government made progress toward implementing the triggers for reaching the floating Completion Point under the enhanced Heavily Indebted Poor Countries (HIPC) Initiative. The macroeconomic environment has improved, as evidenced by the satisfactory performance under the extended SMP. Measures have been implemented in the areas of health and education and, as indicated above, in the privatization of ZNCB and the commercialization of ZESCO. Building on the experience in preparing the 2004-06 MTEF, the MoFNP is working to prepare the MTEF for 2005-07. The Poverty Reduction Strategy Paper (PRSP) progress report was finalized and has been issued to the Boards of the Fund and the World Bank.

\section{The Medium-Term Reform Strategy}

11. As articulated in the PRSP, and re-affirmed in the PRSP progress report, the government's strategy to reduce poverty focuses on promoting economic growth through diversification and improving the quality of public services, while addressing the cross-cutting issues of governance, HIV/AIDS, gender and the environment. Since poverty is concentrated in rural areas, agricultural development will receive a high priority, while the development of the road infrastructure throughout the country will also be a priority to facilitate growth and poverty reduction.

12. The central challenge is to strengthen the recent momentum of economic growth that has begun to reverse the prolonged decline in per capita incomes. The Government recognizes that long-term growth rates of 6 to 8 percent would be needed to reduce poverty in line with the Millennium Development Goals (MDGs). The Government is therefore striving to move the economy towards this higher growth path and reduce poverty by intensifying its efforts to remove obstacles to private sector development and improving the 
delivery of key services. However, the Government also recognizes that it will take time for these reforms to deliver a stronger sustained increase in economic growth. In addition, in line with the MTEF, the strategy for the next three years is developed around cautious projections of external assistance. The Government envisages that successful and consistent implementation of its reform agenda, including fundamental reforms in public expenditure management would, over time, facilitate higher levels of external assistance that could be incorporated into the framework to increase priority spending and reduce the high burden of domestic debt.

13. Key medium-term macroeconomic objectives include: (i) increasing real GDP growth from 3.5 percent in 2004 to at least 5 percent in 2006 and beyond; (ii) reducing the rate of inflation to around 10 percent in 2006 and to single digits thereafter; and (iii) increasing the gross international reserves of the BoZ to about 2 months of import cover by 2007 . The strategy is also geared to restoring a sustainable external debt position by reaching the Completion Point under the HIPC initiative and reducing the external current account deficit to a sustainable level. At the same time, fiscal policy aims to re-orient spending towards priority poverty-reducing expenditures, while reducing domestic debt to sustainable levels.

\section{Agriculture, mining, manufacturing, and tourism are expected to be the main} sources of growth. Agricultural growth will moderate in 2004 after the recovery in 2003 from the drought of the 2001/02 season, and pick up to 4 percent by 2006. With the support of private investment and the positive outlook for prices, the copper sector is expected to contribute strongly to overall growth. Manufacturing is also expected to benefit from higher demand from the mining and agriculture sectors, and prospects for tourism, especially in the Livingstone area, are good. More generally, further progress in macroeconomic stabilization, improvements in the delivery of public services and infrastructure, and the removal of regulatory and other obstacles to private sector development are expected to support stronger private investment and a continuation of the recent trend of higher total factor productivity growth.

15. The medium-term framework embodies a front-loaded fiscal adjustment to halt the cycle of rising domestic debt and interest payments and thus allow high spending on poverty-reducing programs. Given Zambia's relatively high level of tax revenues, this fiscal adjustment is focused more on the expenditure side. The projected fiscal deficit should allow for a sharp reduction in domestic financing from 5 percent of GDP in 2003 to 2.2 percent of GDP in 2004, and a more gradual decline to 0.5 percent of GDP by 2007 . This adjustment will provide for a significant reduction in both the stock of domestic debt and domestic interest payments. The reallocation of spending, and improvements in the efficiency and delivery of government services will be supported by the implementation of the government's Public Sector Reform Programme, with concerted support from development partners. Since work is needed to fully elaborate plans for "rightsizing" and pay reform (see below), which could yield some savings from the current wage bill of 8 percent of GDP, at this stage, the medium term framework reflects the government's policy of holding the wage bill to no more than 8 percent of GDP. Nevertheless, poverty reducing expenditures are targeted to increase over the medium term; within this total, the 
subset of expenditures identified as poverty reduction priorities, which are largely capital expenditures, would increase from 1 percent of GDP in 2003 to 3.8 percent of GDP in 2007.

16. Zambia's medium-term external outlook is expected to improve significantly on the basis of stronger exports and further debt relief once the Completion Point under the enhanced HIPC Initiative is reached. Although copper prices are expected to weaken from their current high levels, strong mining and non-mining exports will allow the current account deficit, including grants and debt relief on interest payments, to narrow from 5.6 percent of GDP in 2003 to 3.8 percent in 2007. The improvement in the overall deficit should permit a buildup of external reserves from 1.3 months of import cover in 2003 to almost 2 months by 2007. Projected financing gaps, after possible additional debt relief from Paris Club creditors beyond HIPC assistance (up to US\$30 million per year), average US $\$ 43$ million per year over 2005-07. These gaps could be covered by additional support from other donors. Zambia's gross external financing needs are expected to decline significantly in 2006 , following the completion of principal payments to the Fund related to the arrears clearance of 1995.

\section{Structural reforms will support the fiscal adjustment and reorientation of} spending through reforms in public expenditure management and restructuring of the public sector. In addition, the program seeks to strengthen the financial system, improve the environment for private sector development and strengthen governance. The initial focus of these reforms will be on public sector management. But with progress towards fiscal stabilization in 2004, the Government expects that reform efforts and administrative capacities would then be increasingly focused on these "second generation" reforms.

18. The Government, in close collaboration with the development partners, is redefining the Public Sector Reform Programme, in order to meet key objectives established in the PRSP and confirmed in the PRSP progress report. The program is comprised of three pillars, and in each of these areas, technical working groups have been elaborating detailed reform proposals and will supervise their implementation. The first pillar, strengthening Public Expenditure Management and Financial Accountability (PEMFA), addresses issues raised in the PEMFA Report, jointly prepared by the Government and the World Bank, and the Assessment and Action Plan (AAP) on the tracking of HIPC expenditures, jointly prepared by the Government, the World Bank and the Fund. The second pillar addresses issues of "rightsizing," pay reform to align government operations to achieving the PRSP objectives, and a sustainable Public Service Pension Fund. The government recognizes that further work is needed to clearly define the reform strategy for rightsizing and pay reform and has requested further assistance from the World Bank in this area as a matter of urgency. The third pillar addresses decentralization and participatory governance. Although the Public Sector Reform Programme is intended to be an integrated reform program, in line with immediate priorities and the progress achieved in defining the reform agenda, the initial focus will be on the PEMFA program, which is critical to improving expenditure policy and management reforms.

19. The Government has launched the Private Sector Development Initiative (PSDI), to improve the environment for private sector growth and accelerate domestic and 
foreign investment. The PSDI was developed from a comprehensive review of current policies, legislation and regulations. A draft of the initiative, which was prepared by a steering committee including representatives of the public and private sectors, as well as development partners, was presented to Cabinet in May 2004 and will be discussed with key stakeholders during a Private Sector Development Forum in June 2004. The key elements of the PSDI include: a revision of Zambia's investment act; a program of land reform; a reform of labor laws; a revision of business regulations and licensing policies; and the development of a new policy on tax incentives. While aiming to facilitate private activity in all sectors, the initiative will also focus on removing obstacles to investment in agriculture, tourism, gemstone production, telecommunications and energy and power. Full implementation of the PSDI agenda is expected to take at least two years. However, some legislative changes needed to support the PSDI are expected to be presented to parliament during the second half of 2004.

\section{The Government is also proceeding with the reform of the electricity utility,} ZESCO. Following the review by Fund and World Bank staff, the commercialization of ZESCO has reached the "entry point" and we intend to expedite implementation of the measures needed to reach the interim point by June 2004 and then embark on ZESCO's commercialization according to the agreed detailed framework. As previously agreed, to provide ZESCO some breathing space to build a track record of credit worthiness, new concessional borrowing by ZESCO guaranteed by the Government will be permitted, subject to cumulative limits of US\$20 million to the end of 2004 and US\$40 million to June 2005. This limit would be subject to review, in consultation with Bank and Fund staff, in the event that additional concessional resources are required.

\section{A draft Financial Sector Development Plan (FSDP) has been issued for comments from stakeholders, and a national forum on the plan was held in May 2004.} The wide-ranging plan, which will be finalized by June 2004, seeks to address issues raised in the Financial Sector Assessment Program. It recognizes the importance of addressing the issue of the insolvent NBFIs, in order to limit the potential exposure to the budget of additional contingent liabilities. The plan also stresses the importance of adequate autonomy in the formulation of monetary policy and, more generally, in strengthening the authority of the BoZ, especially in matters of banking supervision. The Government has also drafted regulations to support the development of the microfinance sector that are expected to come into force in 2004. The draft regulations aim to strengthen the governance of the sector through increased availability of information and better supervision of corporate governance.

22. Reform efforts are also concentrated on improving governance. The anticorruption drive will remain central. In this regard, the Task Force on Corruption has seized money and assets suspected to have been illegally acquired. It is expected that, upon final settlement of any outstanding legal issues related to the monies and assets, in the event the judgment favors the Government, a cabinet memorandum would be issued on the disposal of these assets for the benefit of the people of Zambia. In addition to the measures pursued under the PEMFA program, the Government is strengthening the independence of the Office of the Auditor General and will work on extending to grant-aided institutions and 
state-owned enterprises the financial reporting requirements envisaged for the central government.

\section{The Program for 2004}

23. The key macroeconomic objectives underlying the budget for 2004 are real GDP growth of at least 3.5 percent and end-period inflation of no more than 20 percent. Growth is expected to moderate in 2004 from the revised estimate of 5.1 percent in 2003, reflecting a slower pace of agricultural growth after the recovery in 2003 from the effects of the drought in 2002. The inflation target would imply some increase from the outturn for 2003, reflecting the expectation of a less favorable trend in food prices, which have a heavy weighting in the consumer price index, and the impact of higher petroleum prices on world markets. The program also targets gross international reserves of US\$173 million (about 1 month of import cover) at end-2004.

\section{A. Fiscal Policy}

24. The budget for 2004 is geared to preserving macroeconomic stability, by containing domestic borrowing to reduce pressures on interest rates, prices and the exchange rate. In support of these objectives, the budget and the program for 2004 target a 3 percent improvement in the domestic primary balance, to a surplus of 2.4 percent of GDP. This will also allow government's recourse to domestic financing to decline from 5 percent of GDP in 2003 to 2 percent of GDP in 2004. Although the burden of this adjustment falls primarily on the expenditure side, the Government intends to increase spending on priority poverty-reducing programs.

25. The wage bill will be reduced by 0.5 percent of GDP from 8.5 percent of GDP in 2003 to 8 percent of GDP in 2004. In line with this objective, the Government has announced that there will be no nominal increase in wages, except for the Zambia Police, Immigration and Prison service personnel, who did not receive a raise in 2003. However, the wage bill will accommodate promotion increases or wage creep, and a housing allowance of K 7.2 billion per month and the mid-term gratuity for members of Parliament as provided for by the law. The Government has reaffirmed its intention to hold the wage bill to the budgeted amount and in line with established procedures, a reconciliation board, whose conclusions are not binding, is considering the trade unions' claims and the government position of no general wage increase in 2004. Allocations on ordinary recurrent departmental charges (RDCs) have been reduced by 0.7 percent of GDP from the 2003 outturn of 2.8 percent of GDP. Savings are to be achieved through re-organization of operations, aggressive cutting of discretionary spending, and strict enforcement of the commitment control system (CCS), supported by monthly cash releases from the MoFNP.

26. Despite this fiscal restraint, the Government is committed to increase priority poverty-reducing expenditures financed with HIPC debt relief from 1 percent of GDP in 2003 to about 2 percent of GDP in 2004. The Government will continue to make monthly payments into Account No. 49 at the BoZ to fund these expenditures. However, the balances of line ministries' accounts in commercial banks for these expenditures will be monitored closely and funds will be disbursed to these accounts from Account No. 49 only 
when existing balances are expected to be exhausted during the month. Government, in 2004, has also increased the allocation to the key social sectors, such as education, which has received at least 20.5 percent of discretionary spending.

27. The budget includes measures to raise revenues, which focus on broadening the tax base. The original structure and coverage of the VAT were restored by exempting most nonexport goods that were zero-rated. This measure, which took effect on February 7, 2004, is expected to yield K 95 billion or 0.4 percent of GDP. Increased compliance with the VAT has been facilitated by doubling the turnover threshold for the VAT to K 200 million. At the same time, cancellation of voluntary registration below this threshold should result in savings of K 26.3 billion from VAT refunds. A 3 percent turnover tax, replaced income tax and VAT for companies below the VAT threshold, and should yield K 7.3 billion. In addition, the personal income tax has been restructured to alleviate poverty and provide additional resources to the budget. The revised personal income tax regime, effective April 1, 2004, increases the threshold for exempting annual income to K 3.1 million (from less than K 2 million) and adds two income brackets (at tax rates of 35 and 40 percent) above the current top rate of 30 percent. These measures should yield K 23.8 billion. A 10 percent excise duty on cell phone airtime, introduced on February 7, 2004, should provide $\mathrm{K} 15.6$ billion. The removal of the preferential corporate tax rate for companies listed on the Lusaka Stock Exchange should yield K 17.4 billion. In combination, the tax policy measures are expected to raise revenues by 0.6 percent of GDP. Measures on non-tax revenues (increase of fees and fines) and exceptional revenues (reduction of subsidy on sales of fertilizer) should generate additional resources of 0.4 percent of GDP. Consequently, total revenue collection should reach 18.7 percent of GDP in 2004. Total grants are estimated at 5.4 percent of GDP and include program grants carried over from 2003 and the first disbursement under a new program from the European Union that would be contingent on approval of a new PRGF.

\section{The Government is fully committed to executing the budget as approved by}

Parliament. Specifically, the wage bill will be kept within the budget ceiling of 8 percent of GDP, while monthly transfers to the HIPC Initiative Account No. 49 at the BoZ will provide funding for full execution of poverty-reducing spending. Discretionary spending, in particular under ordinary RDCs, will not exceed budgetary allocations. In the first half of 2004, interest payments in domestic debt are not expected to be significantly different from their budgeted level. Current low interest rates on Treasury bills may give rise to some savings on domestic debt service in the second half of the year, but external debt service payments are now projected to be higher than in the budget. The possible use of any further net savings will be discussed at the time of the first review under the PRGF arrangement.

29. The MoFNP and the Ministry of Commerce, Trade, and Industry are continuing the analysis of the Export Processing Zones Act and the revision to the Investment Act. The Cabinet will review these issues by end-October 2004 and will submit to Parliament, for consideration and approval in the context of the budget for 2005, the amendments needed to make tax incentives sustainable, general, and non-discretionary, while minimizing the risks of erosion of the tax base. 


\section{B. Monetary and Exchange Rate Policies}

30. Monetary and exchange policies in 2004 will be geared to achieving the program's inflation target while safeguarding the international reserve position. In line with these objectives, and taking into account a monetary overhang at the end of 2003, the expansion of broad money will be limited to about 18 percent through the BoZ's use of indirect monetary instruments. The monetary framework provides sufficient room for a significant real increase in credit to the private sector in support of the program's growth objective, and is consistent with the fiscal framework. Although the growth in broad money has so far remained within the programmed range, the $\mathrm{BoZ}$ is closely monitoring liquidity developments. In this regard, the BoZ is taking appropriate measures to mop up excess liquidity to ensure that broad money continues to stay within the programmed limits and is consistent with the projected inflation rate and to prevent pressure on the kwacha.

31. The exchange rate will continue to be market-determined. BoZ intervention in the market will be aimed at meeting the program's gross international reserves target and smoothing short-term fluctuations.

\section{External Sector}

\section{The current account deficit (including grants and debt relief on interest} payments) is projected to narrow from 5.6 percent of GDP in 2003 to 4.6 percent in 2004. Metal export receipts are projected to grow by 30 percent, mainly because of higher copper prices, while nontraditional exports including agricultural products such as sugar, vegetables, cotton, and tobacco would increase by about 12 percent. Prospects in the copper sector could be bolstered by the sale of a majority stake in $\mathrm{KCM}$ to a strategic equity partner and the start of copper production at the newly reconstituted mine in Luanshya. However, export gains are expected to be largely offset by stronger imports, mostly because of large capital expenditures in the mining sector. In addition to the large expenditures on the new Kansanshi copper mine, due to start operations in 2005, the mining sector is also expected to take advantage of high copper prices to finance other capital improvements.

33. External program assistance in the second half of the year will benefit from the approval of the new PRGF. In particular, in line with the budget for 2004, disbursements are expected under a new structural adjustment credit from the World Bank and a new threeyear support program from the European Union. For the period leading up to the HIPCInitiative Completion Point, the Government is requesting for a new rescheduling arrangement on Cologne terms. At the Completion Point, the Government would request a stock of debt operation from this group of creditors. The Government is also negotiating with non-Paris Club commercial creditors to obtain debt relief comparable to that under enhanced HIPC-Initiative debt relief. With the approval of the requested PRGF arrangement, and the official financing it would catalyze, the program would be fully financed in 2004.

34. The trade regime remains open and supportive of export development and the diversification of the economy. The simple average nominal tariff on imports is estimated to have declined in 2003 by 2 percentage points to 11.5 percent, as a result of the 
reclassification of some goods within the four tariff bands. Zambia does not have any nontariff import barriers. The establishment of a common external tariff by the Common Market for Eastern and Southern Africa free trade area, previously scheduled for 2004, is now expected in 2005. As a part of the strategy launched in 2000 to create a Southern African Development Community (SADC) free trade zone by 2012, the gradual reduction of tariffs for sensitive items (Category B of the SADC protocol) will be implemented on July 1,2004 . On export development, the government will benefit from the participation in the Integrated Framework for Trade-Related Technical Assistance to Least Developed Countries.

\section{Structural Reforms, Public Expenditure Management, and Governance}

35. The key structural reforms in the public sector for 2004 will aim to strengthen public expenditure management, improve cost-effectiveness of the public sector, and enhance transparency and governance. A broad-ranging and detailed program of reforms in Public Expenditure Management and Financial Accountability has been elaborated by Government and its development partners, drawing upon the diagnostic work prepared with the World Bank. The PEMFA program will be submitted for consideration and approval to a committee of Cabinet in May 2004 (a prior action for approval of the PRGF arrangement). The Government is determined to implement the PEMFA program, with the assistance of multilateral and bilateral donors. The program will, inter alia, reinforce the budget's role in the definition and execution of spending policy, facilitate enforcement of sanctions for noncompliance with the established spending procedures, support the implementation of the IFMIS, and strengthen internal audit and control.

\section{In line with the implementation of the PEMFA program, initial steps to} strengthen public expenditure management will include the following (i) fully integrating the activity based budget classification in the reporting system by end-May 2004; (ii) signing in June (structural benchmark) the contract for the supply and installation of the hardware and software needed to implement the fully computerized IFMIS; (iii) initiating the piloting of the IFMIS in three ministries before end-September (performance criterion) as a key step towards meeting the related trigger for the HIPC Completion Point on the piloting and midterm review of the IFMIS; (iv) preparing, by September 2004, an improved MTEF as a basis for more realistic and multi-year financial planning. From June 2004, the MoFNP will start to publish quarterly budget execution reports, using the activity based budget classification, within 45 days of the end of the quarter. From August 2004, these reports will include detailed and summary data on the execution of all poverty-reducing expenditures as well as the subset of these classified as priority poverty-reducing expenditures. Based on the audited stock of domestic arrears at end-2003, and a fully elaborated multi-year plan for clearing domestic arrears, the MoFNP will, by July 2004 (structural benchmark), start negotiations with contractors for infrastructure projects accounting for the bulk of these arrears, and initiate payment of arrears on goods and services and personal emoluments. All payments will be made by the MoFNP. The Government will also submit an amendment to the Constitutional Review Commission (CRC) that would enable the budget to be submitted to the Parliament and approved before the start of the fiscal year. 
37. The MoFNP will strongly enforce expenditure procedures. Unbudgeted expenditure requirements will be funded only to the limits of the contingency resources indicated in the budget or only after Cabinet has approved any changes by finding compensatory funding within the approved budget resources. In order to prevent the accumulation of new arrears and virement of resources, the Budget Office in the MoFNP is strengthening timeliness and reliability of quarterly and monthly expenditure ceilings issued to spending agencies. The inclusion of the CCS in the computer-based Financial Management System - a precursor to the implementation of the IFMIS - will considerably improve spending execution. The new system will help ensure that control over monthly expenditure returns is appropriately and timely monitored, while improving transparency and the accountability of accounting officers. The Secretary to the Treasury is supervising strict enforcement of sanctions for noncompliance with the established spending procedures. The Accountant General is reporting on reductions of disbursements to line ministries, departments, and provinces responsible for over-commitment, diversion of funds between budget sub-heads without ex-ante written authorization by the Secretary to the Treasury, as well as failure to accurately report expenditures, as specified in the circulars issued in September 2002.

38. Work is now underway on the development of a strategy of government rightsizing and pay reform. The strategy aims to achieve a public service of optimal size and raise the quality of the services it delivers. The government will review progress in this key area with Fund staff at the time of the first review. In the meantime, efforts are continuing to strengthen control of the wage bill. A new Payroll Management and Establishment Control (PMEC) system, which is now being tested, will adopt phased implementation with the first batch of payrolls going live by end-June 2004 (20 payrolls). The U.K. Department for International Development (DFID) has been requested to support this phased implementation of the PMEC system, which is expected to run from June to December 2004. This system will imply close monitoring and reconciliation for the payroll and Establishment Registers for Ministries and Government Institutions, excluding National Assembly, Electoral Commission, Anti-Corruption Commission, Defense, Office of the President (Special Division), Human Rights Commission and Health Boards. Finally, the Government reiterates its intention to consolidate allowances into basic salaries. In 2005, subject to negotiations with Public Service Unions, the housing allowance will be consolidated in the basic salary, observing the ceilings provided by the MTEF.

39. An action plan for the implementation of the Financial Sector Development Plan is expected to be submitted, by June 2004, to Cabinet, for consideration and approval (prior action). In the meantime, financial sector reforms will focus on immediate priorities. The government is fully supporting the ZPA in its efforts to conclude the sale of 49 percent of the equity in ZNCB. As earlier envisaged, no interest on the bond issued in 2002 to recapitalize $\mathrm{ZNCB}$ will be paid before the sale is concluded. The BoZ will implement regulations for the microfinance sector, to support the use of rural branches of banks to enhance delivery of financial services in rural areas and boost growth in the agriculture sector. 
40. In November 2001, Zambia enacted the Prohibition and Prevention of Money Laundering Act (PPMLA) which, inter alia, criminalized money laundering and provided for the seizure of assets derived from laundered funds. The Act also provided for the establishment of the Anti-Money Laundering Authority, the policy-making organ charged with providing guidance to the Anti-Money Laundering Investigations Unit, the unit charged with investigating money laundering offenses. Whilst these developments provided the necessary impetus to the fight against money laundering, it has been recognized that the provisions of the PPMLA need to be strengthened, largely due to changes in international standards for combating money laundering. In this regard, proposals have been made to review the PPMLA to bring it in line with the revised FATF40 recommendations of June 2003, and Technical Assistance from the IMF has been sourced to help the country come up with the appropriate anti-money laundering legislative framework. The proposals to amend the PPMLA have been presented to the Anti-Money Laundering Authority.

41. Resolution of three insolvent NBFIs remains an immediate priority and the following courses of action are being taken with technical assistance from the IMF:

- Submission to Cabinet by September 2004 of proposals to repeal sections of the Building Societies Act (BSA), the National Savings and Credit Bank Act, and the Development Bank of Zambia Amendment Act that conflict with the Banking and Financial Services Act (BFSA). Repeal of the sections of the Acts will strengthen the BoZ's regulatory and supervisory powers over these institutions. These proposals would be considered by parliament in the December 2004 session.

- In the absence of agreement on a viable business plan for the Zambia National Building Society (ZNBS), the BoZ is taking actions to protect depositors' funds and to limit the ZNBS's operations and is monitoring the institution's performance against a directive to reduce its operating costs. In the event the required steps to reduce it costs are not taken by September 2004 , and that the ZNBS is not able to present a viable business plan, the BoZ will take a decision to invoke additional supervisory action, on which preparations are now being made. In addition, the Government and the BoZ are exploring options to foster the development of private financing for mortgages in Zambia. No public money will be used to recapitalize the bank.

- Government is considering a proposal under which the International Fund for Agricultural Development (IFAD) would contribute US\$2 million to the National Savings and Credit Bank (NSCB) to facilitate the expansion of rural financial services, provided the Government also inject a capital contribution of $\mathrm{K} 5$ billion. The BoZ has also deemed acceptable the Rural Banking Strategic Plan submitted by NSCB to the MoFNP, but will enter into an agreement with the NSCB setting out performance targets including a timebound plan to fully recapitalize NSCB without further government monies only after receiving a commitment from Government in line with the proposal from IFAD. A final decision is expected to be taken by September 2004. 
- Restrictions have been placed on the Development Bank of Zambia (DBZ), pending private sector capital injection of 60 percent of its capital base. No public money will be used to recapitalize the bank. There has been an offer by the Ex-Im Bank of India to invest US\$1.4 million in DBZ, providing certain conditions are met by the Government of Zambia. The Government is willing to meet these conditions, but with government's stake reduced to 25 percent to comply with the requirements of the BFSA. When the remaining private equity is secured, the DBZ can resume operations, subject to the requirements that it cannot accept deposits, enter into "retail banking" and that there be no government guarantee of loans made to the DBZ.

42. The Government remains fully committed to enhance quality of governance and transparency of public sector operations. As indicated in the PRSP, the Government has elaborated and started a policy of zero tolerance for corruption. To improve transparency, the Government is strictly adhering to budgetary procedures. Quarterly reports of budget execution, including poverty-reducing priority expenditures, will be published. In line with last year's timely submission, the audited accounts for 2003 will be submitted to Parliament by end-2004. The Government is also committed to strengthening the independence of the Office of the Auditor General. However, since this will require a constitutional amendment, the Government will present a proposal to this effect to the CRC.

\section{The PRSP Progress Report, the HIPC Triggers, and the MTEF}

43. The Government completed the first PRSP Progress Report in April 2004. The participation of all main stakeholders in the assessment allowed the Government to draw lessons from the first 18 months of PRSP implementation. In the progress report, the Government acknowledges that weaknesses in expenditure policy and management, as well as delays in key structural reforms outside the fiscal area, resulted in delays in implementing poverty-reducing programs.

44. The Government is fully committed to meeting the HIPC triggers. The removal of the debt overhang at the HIPC Completion Point is a key element in eliminating potential obstacles to investment, growth, and poverty reduction. The Government is continuing the commercialization of ZESCO, as envisaged under the plan supported by the World Bank. The development of the 2005-07 MTEF is well underway (and is expected to be finalized by September 2004). In the second half of the year, the Government expects to pilot an IFMIS in at least three ministries. The Government is continuing with its efforts in the execution of programs in the education, health and HIV/AIDS areas, including poverty monitoring programs and the finalization of the privatization of ZNCB. In addition to intensifying reform efforts to meet the triggers, the Government is working on reconciling its debt with all external creditors. A full debt sustainability analysis (DSA) will be completed during the next few months.

\section{Technical Assistance and Data Issues}

45. Zambia will need technical assistance to strength capacity and support program implementation. In the area of public expenditure management, following the expiration 
of the term of the Fiscal Affairs Department (FAD) resident advisor, the MoFNP is requesting further assistance in cash management from FAD. In the financial sector, the BoZ requested Monetary and Financial Systems Department (MFD) assistance on making operational the FSDP. Zambia is a participant in the General Data Dissemination System (GDDS) and is receiving technical assistance in the area of macroeconomic statistics, including BOP, national accounts and government finance statistics, under the project for Anglophone African countries, which is sponsored by DFID. Finally, a data ROSC will be completed in 2004 and will provide the basis for an action plan to improve the quality of statistical information.

\section{Program Monitoring}

\section{Progress in implementing the PRGF-supported program will be monitored} quarterly, based on the quantitative and structural measures indicated in Tables 3 and 4. These targets are defined in the attached Technical Memorandum of Understanding. The Fund will conduct with Zambia two reviews of the annual program based on performance through end-September and end-December 2004, respectively. The first review, which would be completed no later than end-December 2004, would focus on the evolution of the wage bill, progress in developing a costed program for rightsizing and pay reforms in the government sector, and monetary developments. The second review will be completed no later than end-March 2005.

\section{The Government is strengthening the effectiveness of the Economic Management} Monitoring Committee at the MoFNP to provide timely reconciled financing and budgetary data and ensure that preemptive measures are taken to avoid lapses in program implementation. The Fund's Resident Representative continues to be invited to attend the committee meetings as an observer as may be required. 


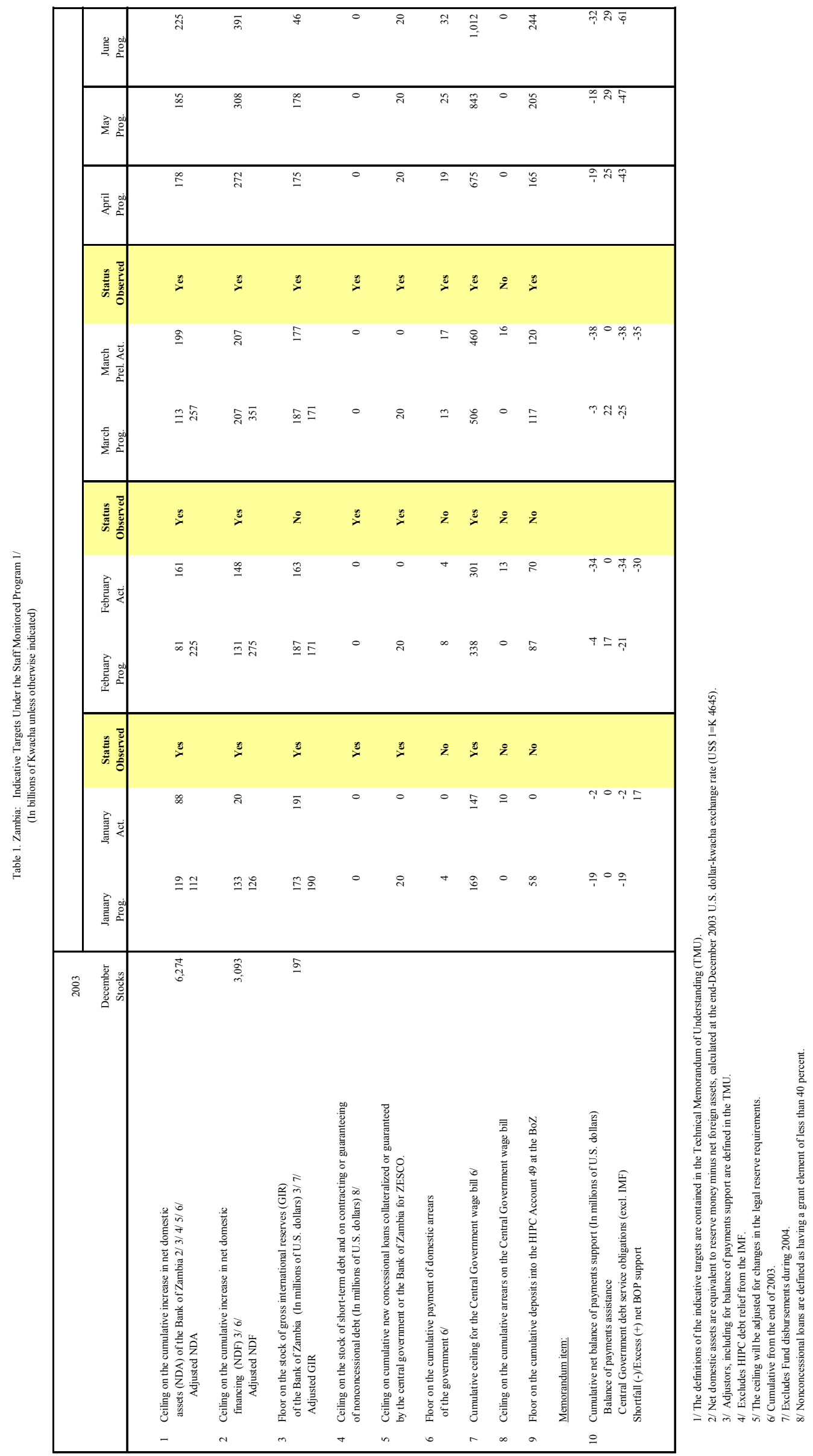




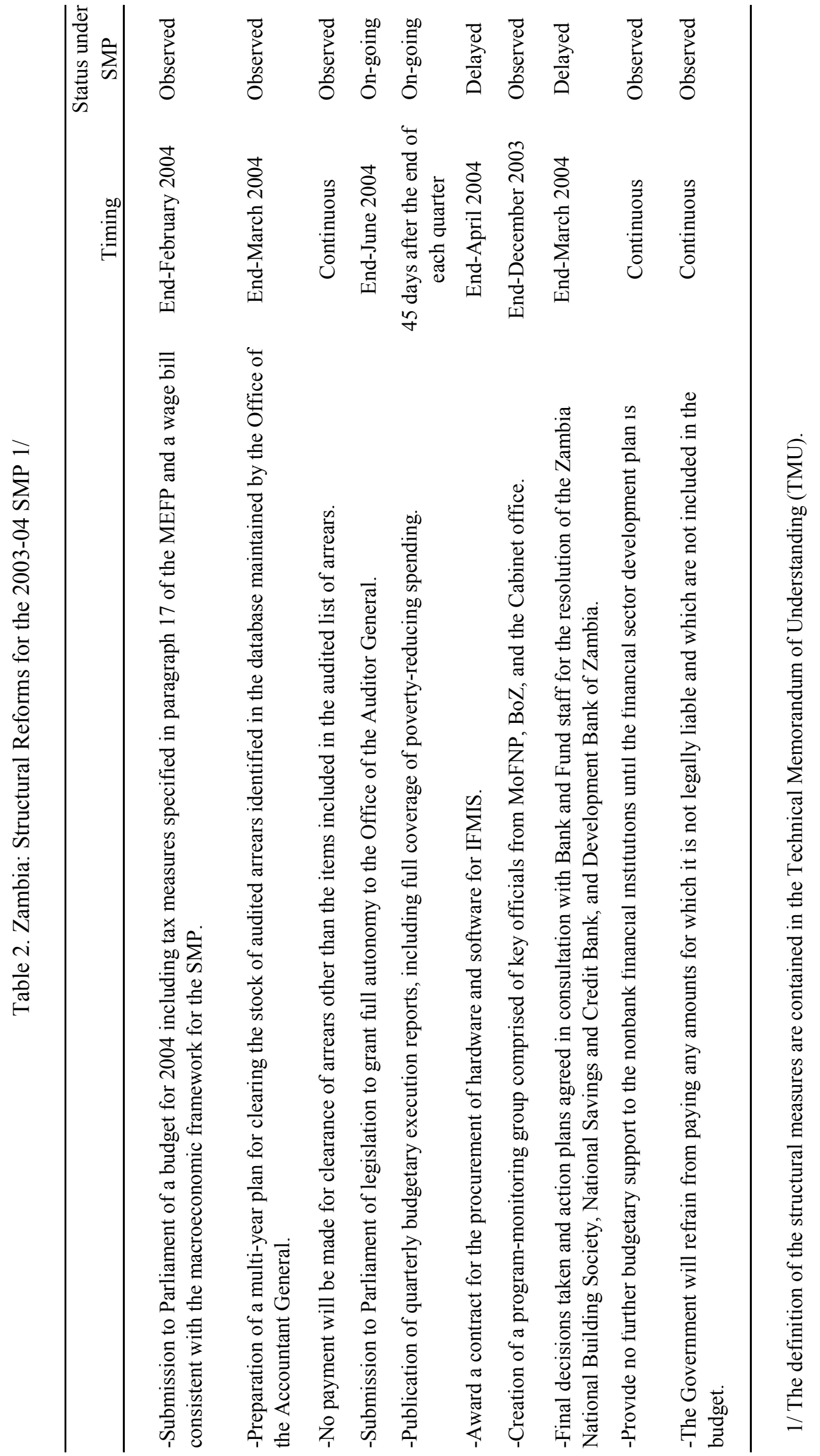


Table 3. Zambia: Quantitative Performance Criteria (PC), Benchmarks and Indicative Targets Under the PRGF Program (In billions of Kwacha, unless otherwise indicated)

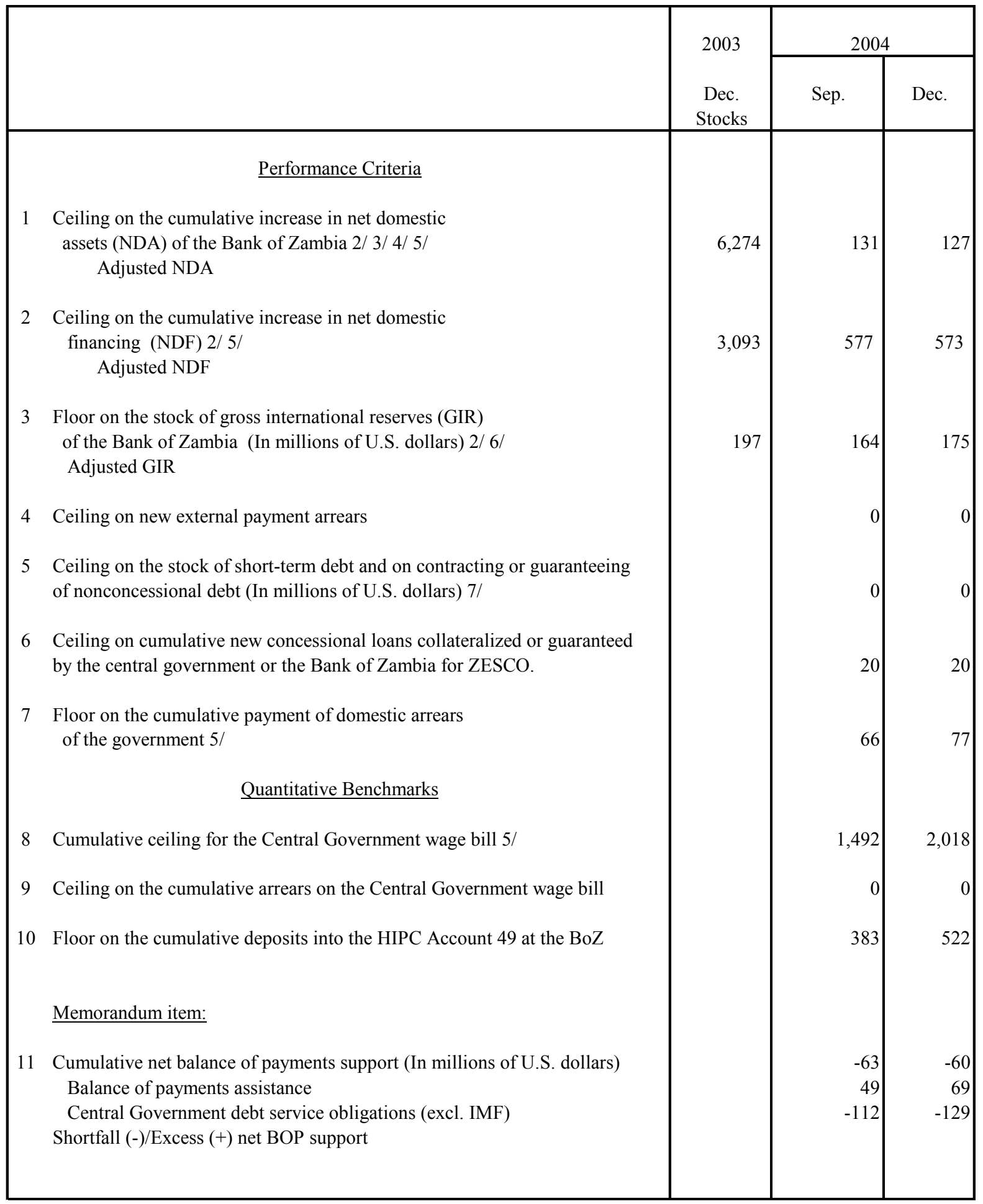

1/ The definitions of the indicative targets are contained in the Technical Memorandum of Understanding (TMU).

2/ Adjustors, including for balance of payments support are defined in the TMU.

3/ Excludes HIPC debt relief from the IMF.

4/ The ceiling will be adjusted for changes in the legal reserve requirements.

5/ Cumulative from the end of 2003.

6/ Includes Fund disbursements during 2004.

7/ Nonconcessional loans are defined as having a grant element of less than 40 percent. 
Table 4. Zambia: Prior Actions, Structural Benchmarks and Performance Criteria 1/

Prior Actions 2/

Cabinet approval of the PEMFA program.

Submission to Cabinet, for consideration and approval, of an action plan for initial implementation of the Financial Sector Development Plan.

Benchmarks and Performance criteria

\section{Public Expenditure Management}

The Government will refrain from paying any amounts for which it is not legally liable and which are not included in the budget. 3/

Publication of quarterly budget execution reports using the activity-based budgeting classfication, within 45 days of the end of each quarter.

Continuous

Award a contract for the supply and installation of the hardware and software needed to implement the IFMIS.

Jun 2004

Start negotiations for settlement of domestic arreas identified in the multiyear plan for clearing domestic arrears

Initiate the pilot implementation of the IFMIS in at least three line ministries. 3/

Sep 2004

\section{Tax Policy}

Define a policy for the granting of tax concessions.

Sep 2004

\section{Financial Sector Reform}

Cabinet approval of a proposal to repeal sections of the Building Societies Act, the National Savings and Credit Bank Act and the Development Bank of Zambia Amendment Act which are in conflict with the Banking and Financial Services Act.

Adoption by the government and the Bank of Zambia of action plans finalized in consultation with the World Bank and IMF staff, for the resolution of the Zambia National Building Society, the National Savings and Credit Bank and the Development Bank of Zambia. 3/

\section{Governance and Transparency}

Unforeseen expenditures will be funded only to the limits of the budget contingency or after Cabinet approval including the identification of savings elsewhere in the budget.

1/ The definitions of the prior actions, structural benchmarks and performance criteria are contained in the Technical Memorandum of Understanding (TMU).

2/ Prior actions should be carried out and reported at least 5 working days prior to the Executive Board discussion.

3/ Performance criteria. 


\section{Zambia: Technical Memorandum of Understanding for The Poverty Reduction and Growth Facility (PRGF) Arrangement}

\section{Introduction}

1. This memorandum sets out the understandings between the Zambian authorities and the International Monetary Fund (IMF) regarding the definitions of the quantitative and structural performance criteria and benchmarks for the program supported by the PRGF arrangement, as well as the related reporting requirements. The definitions are valid at the start of the program, but may need to be revisited to ensure that the memorandum continues to reflect the best understanding of the Zambian authorities and Fund staff to monitor the program.

\section{Prior Actions}

2. The prior actions below should be carried out and reported at least five working days before the Fund's Executive Board discussion. The implementation of the prior action shall be conveyed through a written communication from the Minister of Finance and National Planning indicating that the prior actions have been observed, using the language of the prior action itself.

\section{A. Public Expenditure Management and Financial Accountability (PEMFA) Program}

3. The prior action on the Public Expenditure Management and Financial Accountability (PEMFA) Program will be met following Cabinet approval of the program.

\section{B. Financial Sector Development Plan (FSDP)}

4. The prior action on the Financial Sector Development Plan (FSDP) will be met when the final FSDP with an action plan for its implementation is submitted to Cabinet for consideration and approval. The plan, which addresses issues raised in the Financial Sector Assessment Program, is expected to deal with, inter alia, the issue of the Non-Bank Financial Institutions (NBFIs); strengthening the authority of the Bank of Zambia (BoZ), especially in matters of setting monetary policy and in banking supervision; and microfinance-related issues.

\section{Quantitative Performance Criteria and Benchmarks: Definitions and Data Sources}

\section{A. Net Domestic Assets (NDA) of the BoZ}

5. Net domestic assets (NDA) of the BoZ are defined as the monthly average (based on daily data) of the reserve money less net foreign assets calculated at end-December $2003 \mathrm{BoZ}$ 
mid-exchange rates (program exchange rate). ${ }^{11}$ Reserve money includes currency in circulation, required reserves on Kwacha deposits, required reserves on foreign currency deposits (at the program exchange rate), positive current account balances of banks with the $\mathrm{BoZ}$ and deposits of non-central government institutions. Net foreign assets of the BoZ are defined as gross international reserves (defined below) plus any other foreign asset, including the US\$25 million blocked reserves at the former Meridien Bank (MBZ), minus foreign liabilities (defined below). The Kwacha figures are derived from the U.S. dollar values using the program exchange rate of $\mathrm{K} 4,645$ per U.S. dollar.

6. Foreign liabilities are defined as short term (one year or less in original maturity) foreign currency-denominated liabilities of the BoZ to nonresidents and outstanding use of Fund credit. ${ }^{12}$

7. The ceilings on NDA will be adjusted upward by the amount of the shortfall of balance of payments support net of debt service as indicated in Table 3 (item 11) of the Memorandum of Economic and Financial Policies (MEFP), up to a maximum of US\$14 million for the period end-June 2004 to end-December 2004. External disbursements that occur anytime during the month of the test date will be treated as if they were disbursed on the first day of the month. ${ }^{13}$ In the event of excess balance of payments support net of debt service, the ceiling on NDA will be adjusted downward by 100 percent of the additional excess support. However, if part of the excess support is used to reduce Treasury bills or bonds held by commercial banks and the non-bank sector, then the programmed NDA will be adjusted upward by that amount. The Kwacha value of the cumulative shortfall/excess will be calculated at the program exchange rate.

8. The ceiling on NDA will be adjusted downward/upward to reflect decreases/increases in the legal reserve requirements. The adjustor will be calculated as the percent change in the reserve requirement multiplied by the actual amount of reserves (Kwacha and foreigncurrency denominated) at the end of the previous calendar month.

${ }^{11}$ Unless otherwise defined, program exchange rates for 2004 between the U.S. and other (non-Kwacha) currencies, including the SDR, will be equal to the end-2003 rates. Any other assets (e.g. gold) would be revalued at their end-2003 market prices.

${ }^{12}$ The liability to Camdex will continue to be treated as a short-term foreign liability of the BoZ.

13 This implies that for purposes of monitoring the NDA, disbursements during the month of the test date will not be subject to averaging and the targeted NDA will be adjusted to reflect the full amount of the disbursement. 


\section{B. Net Domestic Financing (NDF)}

9. Net domestic financing (Appendix II, Table 1) is defined as the Central Government's net borrowing from the banking and nonbanking sectors. All government-issued securities will be recorded at cost (face value less discount). NDF will be defined as:

(a) the net position of the Government with commercial banks, including:

(i) Treasury bills; (ii) government bonds; (iii) loans and advances; less (iv) support to MBZ; and less (v) central government deposits (defined to include account balances under the authority of controlling officers); plus

(b) BoZ holdings of: (i) Treasury bills; (ii) government bonds; (iii) the Kwacha bridge loan (overdraft facility); less (iv) the government's position at the BoZ; less (v) the donor suspense account; plus (vi) the long-term non-transferable security issued against government's total indebtedness to BoZ as at end-2002.

(c) Nonbank holdings will include: Treasury bills; and government bonds.

(d) In the event of the Zambia National Commercial Bank's (ZNCB) privatization, the measurement of NDF will exclude the government bond issued to $\mathrm{ZNCB}$ in 2002 in the amount of K 249 billion.

10. The NDF ceiling will be adjusted upward by the amount of the shortfall in balance of payments support net of debt service as indicated in Table 3 (item 11) of the MEFP, up to a maximum of US\$14 million for the period end-June 2004 to end-December 2004. In the event of excess balance of payments support net of debt service, the ceiling on NDF will be adjusted downward by 100 percent of the additional excess support. The Kwacha value of the cumulative shortfall/excess will be converted at the corresponding monthly average of the Bank of Zambia mid rate.

11. The data source for the above will be the "Net Domestic Financing" Table produced by the BoZ Economics Department, submitted on a weekly basis, and reconciled with the monthly monetary survey.

\section{Gross International Reserves of the BOZ}

12. Unless otherwise noted here, gross international reserves of the BoZ will be defined as reserve assets of the BoZ (Appendix II, Table 2). Reserve assets are defined in the IMF BOP manual ( $5^{\text {th }}$ edition) and elaborated in the reserve template of the Fund's special data dissemination standards (SDDS). They exclude, for example, foreign assets not readily available to or controlled by the monetary authorities, and foreign currency claims on Zambian residents. 
13. Gross international reserves consist of (i) monetary gold; (ii) foreign currency in cash; (iii) unencumbered foreign-currency deposits at non-resident banks; (iv) foreign securities and deposits; (v) SDR holdings and Zambia's reserve position with the Fund; and (vi) balances in the BIS account related to debt service to Paris Club creditors. Gross reserves will exclude non-convertible currencies, pledged, swapped, or any encumbered reserve assets including but not limited to reserve assets used as collateral or guarantees for third-party external liabilities, commercial banks reserve requirements in foreign currency, and will exclude the US\$25 million deposit in MBZ, which is under liquidation.

14. The floor on gross international reserves will be adjusted: (i) downward by the amount in U.S. dollars of the shortfall in balance of payments support net of debt service as indicated in Table 3 (item 11) of the MEFP, up to a maximum of US\$14 million for the period end-June 2004 to end-December 2004; (ii) upward by 100 percent of the cumulative excess balance of payments support net of debt service. However, if part of the excess support is used to reduce Treasury bills or bonds held by commercial banks or the nonbank sector, then the programmed reserves buildup will be adjusted downward by that amount; (iii) downward/upward for any shortfall/excess in the U.S. dollar value of disbursements from the IMF under the PRGF arrangement; and (iv) downward for any increase in BoZ short-term foreign currency denominated debt (to resident and nonresidents), using the definition of short-term debt below.

15. For the purpose of this target, as well as those for external debt and arrears, valuation will be in U.S. dollars using the program exchange rate.

16. Data on gross international reserves including its components will be reported by the BoZ on a weekly and end-month basis.

\section{External Payment Arrears}

17. The performance criterion on the nonaccumulation of new external arrears is continuous. Official external payment arrears are defined as unpaid debt service by the Central Government and BoZ, beyond the due date and/or the grace period, if any. This definition excludes arrears subject to rescheduling. It also excludes the accumulation of external arrears that arise from the transfer to non-residents of foreign currency denominated obligations owed by the Government of Zambia to resident creditors.

18. Data on arrears are compiled jointly by the Ministry of Finance and National Planning (MoFNP) and BoZ and will be reported by MoFNP on a quarterly basis.

\section{E. Official Medium- and Long-Term Concessional External Debt}

19. This is defined as all forms of official debt with original maturity of more than one year contracted or guaranteed by the central Government and BoZ having a grant element of more than 40 percent, but excludes debts subject to rescheduling. The grant element is to be 
calculated by using currency-specific commercial interest reference rates (CIRRs) reported by the OECD; for maturities of less than 15 years, the grant element will be calculated based on six-month averages of CIRRs, and for maturities longer than 15 years, the grant element will be calculated based on 10-year averages. Adjustment lending from the IMF will be excluded.

20. This target applies not only to debt as defined in Point 9 of the Guidelines on Performance Criteria with Respect to Foreign Debt (Decision No. 12274-(00/85) August 24, 2000) (see Annex), but also to commitments contracted or guaranteed for which value has not been received. This excludes nonconcessional loans stemming from the rescheduling of external arrears.

21. Detailed data on all new concessional and non-concessional debt contracted or guaranteed will be provided by MoFNP on a monthly basis.

\section{F. Official External Short-Term Non-concessional External Debt}

22. This is defined as the outstanding stock of external debt with original maturity of less than one year owed or guaranteed by the central Government or the BoZ. For this purpose short-term debt will include forward commodity sales but will exclude normal trade credit for imports. There will be no new official external short-term debt during the program period. The term "debt" has the meaning set forth in point No. 9 of the Guidelines on Performance Criteria with Respect to Foreign Debt (Decision No. 12274-(00/85) August 24, 2000).

23. The data will be reported by the MoFNP and BoZ on a monthly basis.

\section{G. Collateralizing/Guaranteeing of Loans to the Zambia Electricity Supply Corporation (ZESCO)}

24. The Government and the BoZ shall not extend or guarantee any new commercial debts to the Zambia Electricity Supply Corporation (ZESCO), including in the form of loans, suppliers credits and leases. New concessional borrowing, as defined above (Paragraph 20), will be subject to a cumulative limit of US\$20 million in 2004. The limit on new concessional borrowing will be subject to review, in consultation with Fund and World Bank staff, in the event that additional concessional resources are required.

\section{H. Domestic Arrears of Government}

25. Domestic arrears are defined as: (i) any bill that has been received by a spending Ministry from a supplier for goods and services delivered (and verified) and for which payment has not been made within 30 days after the due date of payments; (ii) Wage, salary and any payment to government employees, including any direct or indirect scheme of housing allowance, that were due to be paid in a given month but remained unpaid on the $15^{\text {th }}$ of the following month; and (iii) interest or principal obligations which remain unpaid 30 
days after the due date of payment. This definition of domestic arrears excludes changes in the stock on account of interest, penalties and valuation changes.

26. The information is to be compiled through audits of the accounts of spending Ministries and agencies, conducted by the Internal Audit division of the MoFNP. The audits will be completed and data submitted to Fund staff by the Accountant General within six weeks of the end of each quarter.

\section{The Central Government's Wage Bill}

27. For the purposes of the wage bill, the definition of Central Government includes all heads covered in the 2004 Yellow Book. The Central Government's total wage bill will include payments on wages, salaries, allowances, and all other items specified as personal emoluments in the Yellow Book, and any direct or indirect payments of housing allowance to employees. The Government will provide, on a monthly basis and by budget head, the following data: (i) the number of all employees in the Central Government for each budget head; (ii) the basic salary, the allowances and any other personal emoluments released during the month; (iii) the arrears incurred during the month on the basic salary, on the allowances, and on any other personal emoluments; (iv) the number of employees retrenched and the corresponding retrenchment costs; and (v) the number of ghost workers removed from the payroll and the corresponding monthly savings on the wage bill.

28. All the data will be submitted to the Fund staff by the MoFNP within three weeks of the end of each month.

\section{STRUCTURAL PERFORMANCE CRITERIA AND BENCHMARKS}

\section{A. Public Expenditure Management}

29. The MoFNP will publish quarterly budget execution reports using the classification system of activity-based budgeting within 45 days of the end of each quarter..

30. The benchmark on domestic arrears refers to the commencement of negotiations to clear the audited stock of domestic arrears as at end-2002. The negotiations will be based on a revision of the March 2004 arrears strategy which will incorporate a rules-based and transparent strategy for negotiations with contractors. Payments made will be within the budgetary allocations. Within the quarterly expenditure ceilings issued by the Budget Office, the Office of the Accountant General will have the exclusive responsibility to settle the amounts due following the conclusion of negotiations. Line ministries, Departments, and Provinces will not settle any arrears.

31. The Government will award a contract for the procurement and installation of software and hardware needed for the full implementation of the Integrated Financial Management and Information System (IFMIS). 
32. The Government will initiate the piloting of the IFMIS in at least three ministries as a key step towards meeting the related trigger for the HIPC Completion Point on the piloting of the IFMIS and a mid-term review of the pilot.

33. The Government will refrain from making payments for which it is not legally liable, including Zambia National Oil Company (ZNOC) liabilities on liquidation. It will also guide the liquidation process of public enterprises, such as ZNOC, to minimize government's liabilities consistent with the law.

\section{B. Tax Policy}

34. The MoFNP and the Ministry of Commerce, Trade and Industry will elaborate a policy for the granting of tax concessions which will be sustainable, general and nondiscriminatory, while minimizing the risks of erosion of the tax base.

\section{Financial Sector Reform}

35. Cabinet approval of a proposal to repeal sections of the Building Societies Act, the National Savings and Credit Bank (NSCB) Act, and the DBZ, so that these institutions can be incorporated under the Company's Act, to removing inconsistencies with the BFSA and strengthen the BoZ's supervisory powers over NBFIs.

36. The Government and the BoZ, subject to timely provision of technical assistance from the Fund and the World Bank, will adopt an action plan for addressing the weaknesses of the state-owned NBFIs, including the NSCB; the Zambia National Building Society (ZNBS); and the DBZ. The technical assistance will focus mainly on assessing the viability of the business plans of the three institutions and preparing for appropriate supervisory actions. The Government will collaborate with the IMF and the World Bank in preparing the strategic plan and seek necessary technical assistance, including on designing institutional structures to support the development of financial services to rural areas and other related issues.

\section{Governance and Transparency}

37. Unbudgeted expenditure requirements will be funded only to the limits of the contingency resources indicated in the budget or only after Cabinet has approved any changes by finding compensatory funding within the approved budget resources. 


\section{Guidelines on Performance Criteria with Respect to Foreign Debt}

Excerpt from Executive Board Decision No. 6230-(79/140), as revised on August 24, 2000

9. (a) For the purpose of this guideline, the term "debt" will be understood to mean a current, i.e., not contingent, liability, created under a contractual arrangement through the provision of value in the form of assets (including currency) or services, and which requires the obligor to make one or more payments in the form of assets (including currency) or services, at some future point(s) in time; these payments will discharge the principal and/or interest liabilities incurred under the contract. Debts can take a number of forms, the primary ones being as follows:

(i) loans, i.e., advances of money to the obligor by the lender made on the basis of an undertaking that the obligor will repay the funds in the future (including deposits, bonds, debentures, commercial loans and buyers' credits) and temporary exchanges of assets that are equivalent to fully collateralized loans under which the obligor is required to repay the funds, and usually pay interest, by repurchasing the collateral from the buyer in the future (such as repurchase agreements and official swap arrangements);

(ii) suppliers' credits, i.e., contracts where the supplier permits the obligor to defer payments until some time after the date on which the goods are delivered or services are provided; and

(iii) leases, i.e., arrangements under which property is provided which the lessee has the right to use for one or more specified period(s) of time that are usually shorter than the total expected service life of the property, while the retains the title to the property. For the purpose of the guideline, the debt is the present value (at the inception of the lease) of all lease payments expected to be made during the period of the agreement excluding those payments that cover the operation, repair or maintenance of the property.

(b) Under the definition of debt set out in point 9 (a) above, arrears, penalties, and judicially awarded damages arising from the failure to make payment under a contractual obligation that constitutes debt are debt. Failure to make payment on an obligation that is not considered debt under this definition (e.g., payment on delivery) will not give rise to debt. 
Table 1. Net Domestic Financing

\begin{tabular}{|c|c|}
\hline & $\begin{array}{r}2003 \\
\text { End-Dec. } \\
\text { (at cost value) }\end{array}$ \\
\hline Total Domestic Financing (Program) & $3,093,096$ \\
\hline Adjustment for BOP shortfall & 0 \\
\hline Adjustment for RAMCOZ & 0 \\
\hline Adjusted Program DF & $3,093,096$ \\
\hline Excess/Shortfall & 0 \\
\hline Total domestic financing & $3,093,096$ \\
\hline Bank financing & $2,473,417$ \\
\hline Commercial banks & $1,396,970$ \\
\hline Treasury bills $1 /$ & 876,921 \\
\hline Bonds 1/ & 721,381 \\
\hline Loans and advances & 737 \\
\hline less: Support to MBZ & $-8,423$ \\
\hline less: Deposits & $-193,646$ \\
\hline Bank of Zambia & $1,076,447$ \\
\hline Treasury bills $1 /$ & 4,171 \\
\hline Bonds 1/ & 47,066 \\
\hline Kwacha bridging loan & 261,029 \\
\hline GRZ position & $-882,162$ \\
\hline Donor suspense balance & -401 \\
\hline GRZ long-term security IFO BoZ & $1,646,743$ \\
\hline Other & 0 \\
\hline Nonbank financing & 619,679 \\
\hline Treasury bills $1 /$ & 246,495 \\
\hline Bonds 1/ & 373,185 \\
\hline
\end{tabular}

Source: BoZ net domestic financing table.

1/ Measured at cost (face value less discount) starting from end-December 2003. 


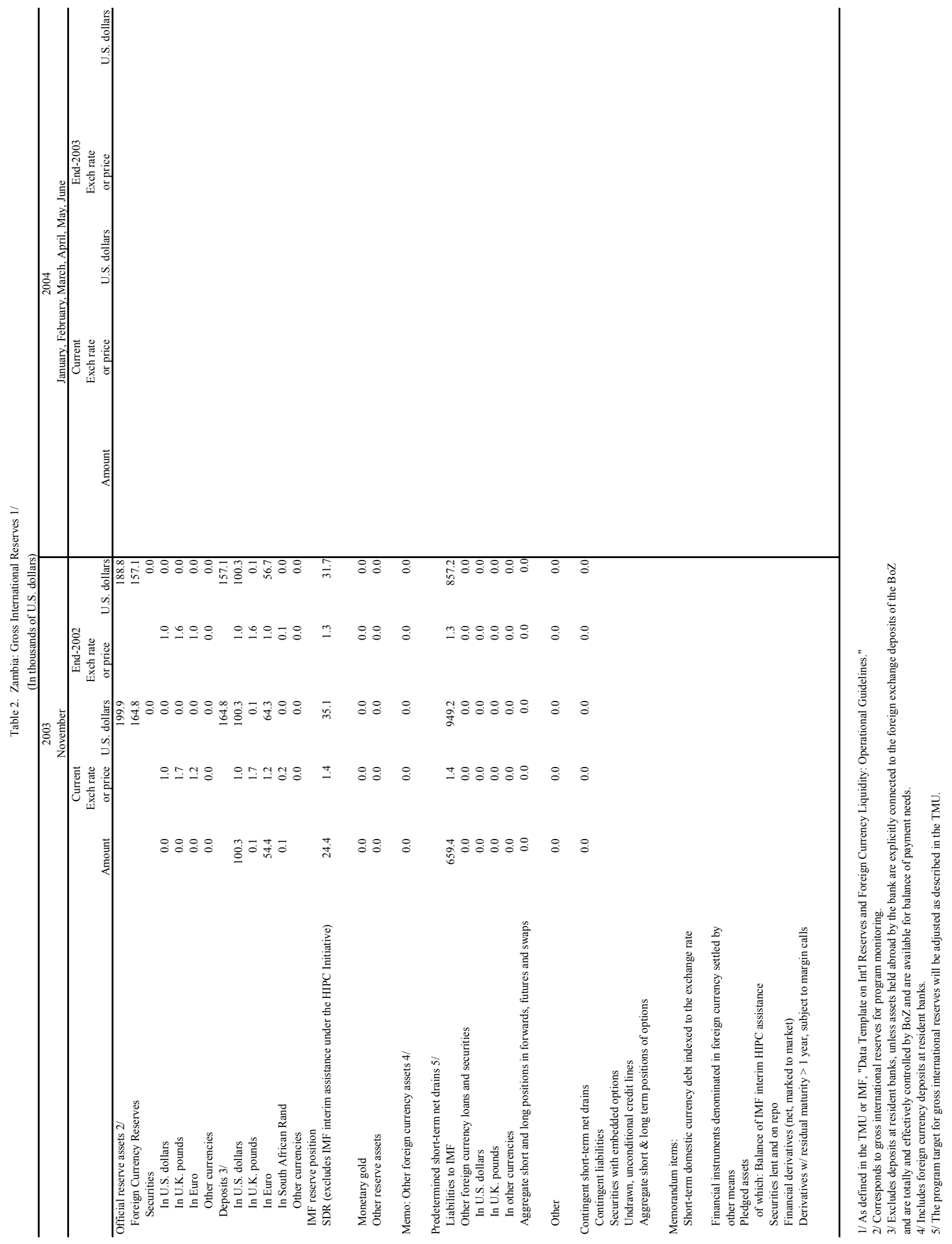




\section{Zambia: Relations with the Fund}

(As of April 30, 2004)

I. Membership Status: Joined: 09/23/1965; Article VIII

II. General Resources Account:

Quota

Fund Holdings of Currency

Reserve position in Fund

$\underline{\text { SDR Million }}$

489.10

\%Quota

100.0

489.10

100.0

.02

.0

III. SDR Department:

Net cumulative allocation

$\underline{\text { SDR Million }}$

68.30

\%Allocation

2.09

100.0

Holdings

3.06

IV. Outstanding Purchases and Loans:

PRGF arrangements

$\underline{\text { SDR Million }}$

504.19

\%Quota

103.09

SAF loans

72.70

14.86

V. Latest Financial Arrangements:

$\begin{array}{lcccc}\text { Type } & \begin{array}{c}\text { Approval } \\ \text { Date }\end{array} & \begin{array}{c}\text { Expiration } \\ \text { Date }\end{array} & \begin{array}{c}\text { Amount Approved } \\ \text { (SDR Million) }\end{array} & \begin{array}{c}\text { Amount Drawn } \\ \text { (SDR Million) }\end{array} \\ \text { PRGF } & 03 / 25 / 1999 & 03 / 28 / 2003 & 278.90 & 237.52 \\ \text { PRGF } & 12 / 06 / 1995 & 12 / 05 / 1998 & 701.68 & 661.68 \\ \text { SAF } & 12 / 06 / 1995 & 12 / 05 / 1996 & 181.75 & 181.75\end{array}$

VI. Projected Obligations to Fund: (Without HIPC Assistance)

(SDR Million; based on existing use of resources and present holdings of SDRs):

Forthcoming

Principal

\begin{tabular}{rrrrr}
\multicolumn{6}{c}{ Forthcoming } \\
\hline$\underline{2004}$ & $\underline{2005}$ & $\underline{2006}$ & $\underline{2007}$ & $\underline{2008}$ \\
168.69 & 170.69 & 10.49 & 26.95 & 47.50 \\
$\frac{2.43}{172.11}$ & $\frac{2.84}{173.52}$ & $\frac{2.22}{12.72}$ & $\frac{2.14}{29.09}$ & $\frac{1.97}{49.47}$
\end{tabular}

Charges/interest

Total

172.1 


\section{Implementation of HIPC Initiative:}

Commitment of HIPC assistance

Enhanced

framework

Decision point date

Dec. 2000

Assistance committed (1999 NPV terms) ${ }^{14}$

Total assistance (US\$ million)

$2,499.00$

Of which: Fund assistance (SDR million)

Completion point date

Floating

Delivery of Fund assistance (SDR million)

Amount disbursed

Interim assistance

351.60

Completion point

Amount applied against member's obligations (cumulative) $)^{16}$

\section{Safeguards Assessment:}

Under the Fund's safeguards assessment policy, the Bank of Zambia (BoZ) was subject to the safeguards transitional procedures with respect to the PRGF arrangement that expired on March 28, 2003. The transitional procedures require a review of only the BoZ's external audit mechanism. The external audit assessment, which was completed on July 2, 2001, concluded that the BoZ's external audit mechanism was adequate. Currently, the BoZ is subject to a full assessment with respect to the expected new arrangement. The safeguards assessment of the BoZ is under way, and should be completed prior to the first review of the new arrangement.

\section{Exchange Rate Arrangement:}

\footnotetext{
${ }^{14}$ Net present value (NPV) terms at the decision point under the enhanced framework.

${ }^{15}$ Including an additional grant contribution of SDR 16.4 million by the Netherlands to Zambia in the context of the enhanced HIPC Initiative.

${ }^{16}$ The amount applied against Zambia's obligations includes interest income earned on resources while in Zambia's subaccount within the Umbrella Account for HIPC Operations.
} 
The currency of Zambia is the kwacha, which is market determined. The official exchange rate quoted by the central bank is the marginal rate determined by auction at the Bank of Zambia's wholesale foreign exchange window. Since end-March 2001, business entities selling foreign exchange amounting to US $\$ 100,000$ or more per week have been required to transact through auctions arranged by the Bank of Zambia. On the basis of the bids and offers received, as well as other considerations, the Bank of Zambia determines the amount of foreign exchange to be sold to, or purchased from, the market. On May 7, 2004, the Bank of Zambia mid-rate was K 4,746.2 per U.S. dollar. On April 19, 2002, Zambia accepted the obligations of Article VIII, Section 2, 3, and 4 of the Articles of Agreement. However, the Fund urged the authorities to eliminate the exchange restriction evidenced by the accumulation of external payments arrears and the multiple currency practice arising from the spreads between the dealing window rate and the interbank rate, which are subject to approval by the Fund under Article VIII, as soon as possible following the introduction of the inter-bank foreign exchange market in July 2003, and the removal of the requirement for exporters to sell their foreign exchange receipts to the BoZ and the auction conducted by the BoZ, the staff is assessing whether the potential for multiple currency practice has been eliminated.

\section{Article IV Consultations:}

Zambia is on the standard 12-month Article IV consultation cycle, subject to the provisions of the decision on consultation cycles approved on July 15, 2002. The last Article IV consultation was concluded by the Executive Board on April 7, 2004.

\section{FSAP Participation and ROSC:}

Zambia has participated in a financial sector assessment program (FSAP) and an FSAP mission from the Fund and the World Bank conducted a comprehensive external assessment of the financial system. The two FSAP missions visited Zambia during April 30-May 15 and July 1526, 2002.

The Zambian authorities have agreed to the preparation of a fiscal transparency module of a Report on Observance of Standards and Codes (ROSC) assessing compliance with the IMF's Code of Good Practices on Fiscal Transparency - Declaration of Principles. Based on the findings of a mission that visited Zambia during May 23-June 5, 2001, the fiscal module of the ROSC was issued to the Executive Board on October 31, 2001. 
XII. Technical Assistance (since 1997):

\section{Resident advisors}

\section{Department}

MFD

FAD

1997-2001

2002-2003

1994- 98

1998-99

1998-99

\section{Technical assistance missions}

Department

MFD

STA

\section{Dates}

November 2000

June 2001

November 2001

September 2002

January and May 2003

September 2003

June 1997

November 1997

March 1998

May 2000

June 2002

June 2002

June 2002

July 2002

\section{Position}

Senior Operations Advisor

Monetary Advisor on Monetary Policies and Investments

Advisor on Monetary Operations

Advisor on Budget Management

Advisor on Public Expenditure

Management

\section{Purpose}

Bank supervision

Bank supervision

Monetary policy, financial sector issues, and payments system

Foreign exchange market

Development of foreign exchange interbank market, monetary operations, and reform of the financial system

Monetary operations, reform of the financial system, government securities market, and payments system.

Monetary survey (combined STA/AFR mission)

Balance of payments

Monetary survey

Balance of payments

General Data Dissemination System (GDDS)

Government Finance Statistics (GDDS)

Real Sector (GDDS)

Monetary Statistics (GDDS) 
FAD

March 2000

January 2001

May-June, 2001

August 2001

December 2002

\section{Resident Representative:}

Budget management

Public expenditure management

ROSC - fiscal transparency module

Tax policy issues

Inspection mission to review the progress in public expenditure management reform

A Fund Resident Representative first took up the position in Lusaka in June 1990. Mr. Joseph Kakoza is the Resident Representative since October 2003. 


\section{Zambia: Relations with the World Bank Group}

\section{A. Partnership for Development}

1. The IDA and IMF Boards endorsed the Government's Poverty Reduction Strategy, covering the period 2002-2004, embodied in its first full PRSP, in May of 2002. An Interim Poverty Reduction Strategy Paper (I-PRSP) had been presented to the Board in July 2000. The PRSP was substantially complete when the new Government took office in January 2002. The new Government endorsed the PRSP and went further to expand the PRSP in the Transitional National Development Plan (TNDP) that was published in October 2002.

2. Strategic focus of the PRSP. The PRSP highlights the following barriers to poverty reduction: lack of economic growth, high inequality, excessive dependence on foreign aid, poor prioritization of public resources, inadequate safety nets, and HIV/AIDS. Therefore, the PRSP seeks to achieve poverty reduction through promoting (i) economic growth and diversification of production and exports; (ii) improved access and quality in the provision of social services; and (iii) the mainstreaming of crosscutting issues of governance, HIV/AIDS, gender, and the environment. Targets and indicators are provided for each sector and sub-sector. For example, by 2004 the poverty headcount is to be reduced to 65 percent, the same as in 1996. Even though the MDGs are not explicitly mentioned in the PRSP, given that the MDGs were not widely discussed when Zambia prepared its PRSP, some of the targets for improvements in the social indicators are similar to the MDGs.

3. Joint Staff Assessment of the PRSP. Bank and IMF staff are in agreement with the major objectives set out in the PRSP. The strengths of the PRSP are: a participatory process that involved civil society, the private sector and the donors; a poverty analysis that draws on available quantitative and qualitative data, looks at multiple dimensions of poverty, and provides data broken down by socio-economic group, gender, and region; an appropriate macroeconomic framework and financing plan; identification of priority sectors likely to contribute most to propoor growth; and the emphasis placed on the need to improve governance and reduce corruption.

4. Since 1995, the Fund has supported by ESAF and PRGF arrangements Zambia's economic reform program. During December 2003-May 2004, the authorities are expected to implement an extended Staff Monitoring Program (SMP), which is to form the basis of a new Fund-supported program under the Poverty Reduction and Growth Facility. The extended SMP focuses on (i) fiscal consolidation; (ii) inflation reduction, and (iii) maintaining an adequate level of foreign reserves. Successful performance under the extended SMP and subsequently under the proposed PRGF would lift a key constraint to reach HIPC Completion.

\section{B. World Bank Group Strategy}

5. The Bank's executive Board discussed the Bank's current Country Assistance Strategy (CAS), which outlines the roadmap for the Bank's country support for the period 2004-2006 in 
March 2004. The CAS is explicitly rooted in a results framework, which links Zambia's overall goals of the PRSP/TNDP to specific strategic objectives, which are measured by long-term outcomes. Paying attention to cause-and-result linkages, the main focus of the planned Bank activities is to improve the enabling environment through interventions that remove obstacles to longer-term strategic development outcomes. Where appropriate, quantitative targets to be reached during the CAS period have been specified. For the CAS period, the Bank will track progress on specific CAS outcomes and intermediate progress indicators that are directly affected by Bank interventions.

6. World Bank activities focus on three strategic priorities:

1. Strategic Priority 1: Sustained Economic Growth Anchored in a Diversified and Export-Oriented Economy;

2. Strategic Priority 2: Improved Lives and Protection of the Vulnerable;

3. Strategic Priority 3: Efficiently and Effectively Managed Public Sector.

In addition to ongoing Bank lending operations in the areas of Public Sector reform, Privatization, Health, Education, Social service delivery, infrastructure, and the environment, the base case of the new CAS includes adjustment lending and support for diversification, while continuing project support for public sector reforms, infrastructure, sanitation, health and education, and a reengagement in the agricultural sector.

7. The Bank continues to undertake substantive country diagnostics providing a solid base for policy dialogue, design, and implementation of its lending operations in Zambia. A combined Public Expenditure Review (PER), Country Procurement Assessment Review (CPAR), and Country Financial Accountability Assessment (CFAA), was completed in 2003. The main economic sector work currently in preparation are a Country Economic Memorandum (CEM), an Investment Climate Assessment (ICA), and Administrative Barriers study (AB), and a Strategic Country Gender Assessment (SCGA). In addition, a collaborative Poverty and Vulnerability Assessment (PVA) is currently underway.

8. For FY06 a re view of labor market regulations, a rural development strategy, a post privatization copper strategy, and a integrated framework study for trade have been planned. In the social sectors, the Bank plans to undertake a public expenditure review of the educational sector in FY06.

9. Zambia has concluded the 1999-2003 CAS period in the low case scenario, which has become the departure platform for the current CAS. 97. Starting from the low case of the last CAS of about US\$65 million in IDA commitments per year (actuals for FY02/03 were US\$132 million in total) the proposed resource envelope under the new low case scenario is US\$180-240 million for the period FY04-07.

10. The next higher level, the base case scenario, would result in US\$70-80 million p.a., or between US\$280-320 million in total which would exhaust the current IDA allocation, which is SDR230 million for FY04-07. In case that Zambia's performance is sustained and even 
accelerated with regard to macroeconomic and structural reforms, and PRSP implementation, the new high case would call for exceptional allocation of IDA resources during the 2004-2007 CAS period and would be between US\$90-105 million p.a. or US\$360-420 million in total which would be a 30 percent increase over the current IDA envelope.

11. The Bank's active portfolio as of March 2004, contains 15 IDA credits, including recent approvals) for a total commitment of US\$610 million (see Table 1). During FY03, 3 projects were approved while 2 projects during FY04 as of March 2003, were approved: (i) Copperbelt Environment in (month/year of approval); (ii) Emergency drought recovery project in (month and year of approval); (iii) HIV/AIDS project (ZANARA) in (month and year of approval); (iv) Southern African Power Pool (Subregional Project) in (December 2003); (v) Road Rehabilitation and Maintenance Project (RRMP) in March 2004.

Table 1. Zambia: Summary of World Bank Operations (As of January 30, 2004)

(In U.S. millions)

\begin{tabular}{lccc}
\hline & Active Projects & & \\
& & & \\
Project name & $\begin{array}{l}\text { Fiscal } \\
\text { Year }\end{array}$ & IDA & Undisbursed \\
\hline & & & \\
\hline & 1999 & 40.0 & 17.0 \\
Basic Education Subsector Investment & & & \\
$\quad$ Programme & 2003 & 40.0 & 40.0 \\
Copperbelt Environment & 1996 & 40.5 & 12.5 \\
ERIPTA & 2004 & 50.0 & 50.0 \\
Road Rehabilitation Project & 2004 & 5.0 & 5.0 \\
South African Power Pool & 2003 & 50.0 & 28.7 \\
Emergency Drought Recovery Project & 2003 & 42.0 & 48.4 \\
HIV/AIDS (ZANARA) & 2000 & 37.7 & 22.4 \\
Mine Township Services Project & 2000 & 28.0 & 9.7 \\
Public Service Capacity (PSCAP) & 2001 & 15.0 & 11.8 \\
Regional Trade Facilitation Project-Zambia & 2000 & 64.7 & 39.9 \\
Social Investment Fund (ZAMSIF) & 2001 & 25.0 & 25.1 \\
TEVET & 2001 & 27.0 & 4.8 \\
Zambia Railways Restructuring Project & 1998 & 70.0 & 10.9 \\
Zambia National Road & 1998 & 75.0 & 25.4 \\
Zambia Power Rehabilitation & & 609.9 & 352.0 \\
&
\end{tabular}

12. International Finance Corporation (IFC) is very much aligned with the Bank's policy agenda in Zambia. The IFC currently has a small portfolio of 12 projects totaling US $\$ 15$ million outstanding. These are a mix of financial sector, agribusiness, telecommunications (mobile telephone), and tourism projects. IFC's most prominent recent project was for US\$30 million in the equity of Konkola Copper Mines (KCM) with Anglo-American in 2000. IFC exited in 2002 along with Anglo, in accordance with the terms of the investment agreement.

13. Zambia is currently a group 3 country for IFC (as defined in the recently board approved IFC strategic initiative for Africa), and thus assessed as a relatively poor investment climate with limited prospects for stimulating new private investment, and limited progress on reforms to improve the investment climate. In this environment, IFC seeks to be responsive to individual projects where IFC can play a role, and in which there is strong development impact, but does 
not invest significant resources in upstream project development. IFC is exploring jointly with the Bank how to support the Bank Group's activities on improving the investment climate in Zambia.

14. MIGA's outstanding portfolio in Zambia consists of four contracts of guarantee in the agribusiness and manufacturing services sector with a US\$36.1 million gross exposure and a US\$35.7 million net exposure as of December 2003. The projects are for the privatization, modernization, and expansion of a foundry, and for cobalt and copper facilities. They benefit the Zambian economy by saving production costs and by providing training to personnel working on projects. The estimated total amount of foreign direct investment facilitated to date is US\$155.5 million. Currently, MIGA is underwriting a project in the infrastructure sector, with expected coverage of US\$20 million, which is expected to be signed in FY04.

\section{IMF-World Bank Collaboration in Specific Areas}

15. A summary of IMF-World Bank collaboration in Zambia is provided in Table 2. There are a number of areas where the Fund leads and its analysis serve as inputs into the World Bank policy formulation and advice, including policies to maintain macroeconomic stability, fiscal, monetary, and exchange rate policies. There are other areas in which the Fund and the Bank share responsibility and are coordinating closely their policy advice to the Zambian authorities, such as trade policy, financial sector, public expenditure management, including debt management, and improving economic governance. The Bank has taken the lead in the social sectors, including health, education, social protection, and water and sanitation, agriculture and rural development, private sector development including regulatory issues and the environment.

16. The Fund and the Bank shared joint responsibility in supporting the Government in the preparation of the PRSP and its forthcoming first progress report assessing its implementation. The Fund and the Bank have also jointly provided assistance to Zambia for evaluating progress to reach the Completion Point under the Enhanced HIPC initiative. In addition, the Bank and the Fund will jointly evaluate Zambia's debt and cash management practices.

\section{C.1. Areas in which the World Bank leads and there is no direct IMF involvement}

17. Areas in which the Bank leads and there is no direct involvement of the IMF are support for social sectors, agriculture and rural development, economic diversification, infrastructure, and the environment. In light of the complex and crosscutting nature of risk and vulnerability in Zambia, the Bank is assisting Government in developing a cross-sectoral Social Protection Strategy. The strategy will extend beyond traditional ex post risk-coping measures (e.g. safety nets) to include a better understanding of the role of ex ante risk-prevention and risk-mitigation measures. The strategy is being prepared in a highly participatory fashion, with the aim of integrating it within Zambia's next PRSP. For the same purpose the Bank will undertake a Poverty and Vulnerability Assessment.

18. HIV/AIDS and health. At this time, IDA is assisting the Ministry of Health with a US\$12 million subcomponent under multi-sectoral AIDS program (ZANARA). In addition, IDA 
is carrying out ESW on human resources in the health sector (FY04) and planning a health sector PER in FY06. Assistance to the Ministry of Health will be expanded through a proposed Health Sector Credit in FY06. Building on this, IDA will provide support for the Health Sector Support Program (SWAp) beginning in FY07. The improvement of water supplies under the Mine Township Services Project will also contribute to improved health outcomes in the areas served.

19. In education, the Bank is currently supporting the Ministry of Education's efforts through Adaptable Program Lending (APL). The APL1 Credit enables IDA funds to be devoted to a wide range of purposes in basic education and, following an amendment, to construct two high schools in Eastern Province. IDA expects that the APL2 Credit, to be committed in FY06, will support the education sector more broadly. The Bank will support the expenditure effectiveness and efficiency and management issues in the sector through a sector focused public expenditure review.

20. In the area of technical education, vocational, and entrepreneurship training (TEVET), the Government is carrying out reforms aimed at improving the quality of TEVET training, making it more responsive to labor market demand, making it financially sustainable, and increasing the participation of female trainees and trainees from socio-economically disadvantaged groups. The Government's efforts in this area are being supported by an IDA Credit committed in FY01, and by several other partners.

21. In agriculture and rural development, the Bank's focus is two fold: one to improve productivity of the sector and the other to increase overall food security. The Bank is reengaging in the agricultural sector given the priority Zambia itself attaches to this sector as set out in the PRSP/TNDP. Indeed, if the macroeconomic environment can be improved, supporting infrastructure put in place and an improved agricultural sectoral policy defined, a major effort could be launched to unleash this growth and poverty reduction potential through well-targeted interventions for both smallholders and commercial agriculture.

22. AAA is planned to support the formulation of an agricultural policy that is consistent with planned and ongoing activities in related sectors such as roads and electricity to remove bottlenecks that prohibit and or make it difficult for farmers to produce for the market. Hence, the policy dialogue with the Government on reform and priorities of public spending for agriculture and rural development will address both short run policy issues holding back the sector, as well as helping formulate a long run strategy to tap the large agricultural export potential of the country, through investment in land development, irrigation, and infrastructure. Balanced treatment of smallholders and commercial agriculture is important for growth and poverty reduction. As a follow-up to the AAA work, an Agricultural Support Project is planned to assist the Government with these challenges.

23. In addition, the Bank is assisting Zambia in developing an Integrated Framework for Disaster Relief and Mitigation-intended as multi-sectoral response to anticipate and address the impacts of climate shocks-under the ongoing Emergency Drought Recovery Project (EDRP). The aim is to increase food security and protect living conditions for the poorest and most vulnerable in target districts; pilot programs are being designed to manage and protect against 
climate shocks, including dams and local irrigation, labor intensive public works, and agriculture input distribution programs. Feeding programs will be implemented in primary schools in a subset of districts; young children in Zambia are particularly at risk to high and rising levels of malnutrition.

24. The Bank supports economic diversification directly through its SEED project, which will support the Government's implementation of a diversification strategy in the tourism, agribusiness, and gemstone sectors. In the initial phase, the SEED project will focus on supporting the design and establishment of appropriate policy and legal frameworks to encourage private investments in the three high potential sectors as well as also investments, primarily in tourism-related infrastructure. The tourism component will work toward making Livingstone the flagship tourism destination in Zambia and strengthen management of national parks, which underpin Zambia's medium term tourism development strategy. The interventions in the gemstones and agribusiness components are to strengthen the supply chain that links rural/smallscale producers to local and export markets.

25. Private sector development. To improve Zambia's investment climate, the Bank and IFC will assist the Government with analytical work, notably an Investment Climate Assessment and a FIAS-led Administrative Barriers to Investment study. These studies are geared to facilitate the adoption of a new and more business friendly investment act and result in regular consultations between business and Government to discuss how to strengthen Zambia's business climate.

26. In the infrastructural sectors, the economic program agreed to as part of the HIPC initiative will assist the need to turn ZESCO around into a financially viable company that operates on commercial terms. Analytical work will assist the Government with identifying main bottlenecks with regard to competition and effective service delivery in the sector. The policy recommendations and institutional changes would be supported through adjustment operations, while the ongoing and proposed investment projects, Road Rehabilitation and Maintenance Project (RRMP) and the Water Sector Reform Project, would provided financial resources needed to undertake the actual investments. Zambia will also benefit from the Southern African Power Pool Project.

27. Environmental concerns are addressed as part of each individual project as laid down in the Bank's safeguard policies and directly through the Bank's environmental project in the Copperbelt, which will assist Government with the cleanup of several hazardous sides in the Copperbelt and Kabwe area. The proposed SEED project will assist the Government with sustainability of tourism in protected areas.

\section{C.2. Areas in which the World Bank leads and its analysis serves as input into the IMF program}

28. The Bank leads the dialogue on institutional dimensions of public expenditure management and financial accountability as well as public sector reform and restructuring and privatization. The Bank program will support these areas through a combination of lending and 
analytical work. In the area of institutional dimensions of public expenditure management and financial accountability, the Bank's long-term objective is to encourage a more transparent and accountable public sector by improving budget management, procurement systems, and the accountability of public funds. The public sector reform and restructuring agenda centers on the need to instill a more productive and efficient public service. The means to achieve this are creating a more qualified and motivated civil service, developing a strategic management orientation in line ministries, improving policy coordination and implementation, and lastly, strengthening local government's capacity to participate in the development process.

29. While the Bank has taken the lead in privatization, the IMF has also a strong interest in these areas since many of the reforms are critical to achieving macroeconomic stabilization and enhancing Zambia's growth prospects. Accordingly, there is a high degree of consultation and coordination between the two institutions on these matters.

\section{C.3. Areas of shared responsibility}

30. The Fund and the Bank are working jointly in the following five areas (i) trade policy;

(ii) financial sector reform; (iii) debt management and domestic debt market development;

(iv) PRSP monitoring and evaluation; and (v) progress towards HIPC completion.

31. In the area of trade policy the Bank with collaboration from other partners will undertake the integrated framework exercise. Follow up with regard to the recently completed FSAP will guide the Bank's policy dialogue and interventions in the financial sector in close collaboration with the IMF. The Fund and the Bank recently jointly reviewed the proposed Financial Sector Development Plan for the financial sector in Zambia.

32. Assistance in the areas of central government debt management and domestic debt market development from the World Bank and the Fund will focus on improving the functioning of these interrelated concepts as a means to reduce vulnerability and the cost of and the need for domestic financing. This work will draw from the Guidelines for Public Debt Management (published in March 2001) and the Handbook on Developing Government Bond Markets (published in July 2001). The World Bank and the IMF have recently prepared an accompanying document to the Guidelines containing case studies from a range of countries at different stages of economic and financial development which will feed into this work as well.

33. As one area of truly joined responsibility, the Fund and the Bank are working closely together to review progress with Zambia's PRSP. The Bank and the Fund jointly prepared the JSA for the full PRSP published in May 2002 and a JSA of the first progress report of the PRSP in May 2004. Another truly joined responsibility is with regard to the Enhanced HIPC Initiative. Zambia reached its decision point in December 2000. The Fund and the Bank jointly prepared the HIPC-AAP document and jointly monitor progress towards HIPC completion. 


\section{C.4. Areas in which the Fund leads and its analysis serves as input into the World Bank program}

34. The Fund leads the dialogue on macroeconomic framework in particular with regard to fiscal policy, advising the Government on the overall envelope for public expenditures, tax policy, as well as monetary and exchange rate policy. In these areas the Bank takes into account the policy recommendations of the Fund and ensures that its own policy advice, embedded in its adjustment lending, is consistent. 


\section{Table 2: IMF-World Bank Collaboration in Zambia}

\begin{tabular}{|c|c|c|c|}
\hline CAS Component & \begin{tabular}{|c|}
$\begin{array}{c}\text { Specialized advice } \\
\text { from Fund }\end{array}$ \\
\end{tabular} & $\begin{array}{l}\text { Specialized advice } \\
\text { from World Bank }\end{array}$ & Key Instruments \\
\hline \multicolumn{4}{|c|}{ Goal: A growth conducive macro economic environment } \\
\hline $\begin{array}{l}\text { Subject: Economic } \\
\text { Framework/ } \\
\text { Management }\end{array}$ & $\begin{array}{l}\text { Monetary policy; } \\
\text { Financial sector } \\
\text { consolidation, } \\
\text { exchange rate, } \\
\text { fiscal policy and } \\
\text { wage bill, debt } \\
\text { management, } \\
\text { balance of } \\
\text { payments, } \\
\text { economic statistics }\end{array}$ & $\begin{array}{l}\text { Debt management; } \\
\text { Wage bill } \\
\text { management; } \\
\text { Financial sector } \\
\text { consolidation }\end{array}$ & $\begin{array}{l}\text { IMF: SMP and PRGF performance criteria } \\
\text { and benchmarks on key monetary and fiscal } \\
\text { targets, and structural reforms; benchmark on } \\
\text { arrears } \\
\text { Bank: } \\
\text { Ongoing portfolio: Public sector capacity } \\
\text { building project (PSCAP) (FY00) } \\
\text { New Lending: SAC (FY05) } \\
\text { ESW: Debt Management Assessment } \\
\text { Jointly: JSA of PRSP progress report }\end{array}$ \\
\hline \multicolumn{4}{|c|}{ Goal: $A$ diversified and export oriented economy } \\
\hline $\begin{array}{l}\text { Subject: Private } \\
\text { sector development; } \\
\text { Trade and export } \\
\text { diversification }\end{array}$ & $\begin{array}{l}\text { Financial sector } \\
\text { reform; trade } \\
\text { policy; exchange } \\
\text { rate policy }\end{array}$ & $\begin{array}{l}\text { Economic growth, } \\
\text { investment climate } \\
\text { for private sector } \\
\text { (infrastructure } \\
\text { services, reforms of } \\
\text { financial sector and } \\
\text { pension funds, power } \\
\text { and } \\
\text { telecommunication } \\
\text { sector reforms, } \\
\text { vocational training), } \\
\text { trade policy for } \\
\text { export diversification, } \\
\text { rural development, } \\
\text { environmental } \\
\text { regulations for the } \\
\text { mining sector }\end{array}$ & $\begin{array}{l}\text { IMF: SMP and PRGF performance criteria } \\
\text { and benchmarks on key monetary and fiscal } \\
\text { targets, and structural reforms. } \\
\text { Bank: } \\
\text { On-going Portfolio: ERIPTA, Copperbelt } \\
\text { Environment Program, ROADSIP, Mine } \\
\text { Township Services Project (FY00), Regional } \\
\text { Trade Facilitation Project (FY00), Railways } \\
\text { Restructuring Project (FY00), TEVET (FY00) } \\
\text { Zambia Power Rehabilitation } \\
\text { New Lending: SAC (FY05), Support to } \\
\text { Economic Expansion and Diversification } \\
\text { (SEED) (FY05), PMSP (FY05), Increased } \\
\text { Access to Electricity, South Africa Power } \\
\text { Pool } \\
\text { ESW: Country Economic Memorandum } \\
\text { (FY04), Investment Climate Assessment } \\
\text { (FY04), ICT Options Study (FY06), Energy } \\
\text { Services Delivery } \\
\text { Jointly: FSAP (FY02) and follow up, JSA of } \\
\text { PRSP progress report }\end{array}$ \\
\hline \multicolumn{4}{|c|}{ Goal: Better health and long-term survival, with particular focus on at risk and vulnerable groups } \\
\hline Subject: Health & & $\begin{array}{l}\text { Health Sector } \\
\text { Expenditure } \\
\text { Management. } \\
\text { Provision of } \\
\text { sustainable water } \\
\text { services in provinces } \\
\text { and districts }\end{array}$ & $\begin{array}{l}\text { Bank: } \\
\text { On-going Portfolio: ZANARA (FY03), } \\
\text { ZAMSIF (FY00), Mine Townships Project } \\
\text { (FY00) } \\
\text { New Lending: Health Sector Support Program } \\
\text { (FY07), PRSC Health (FY07) (high case only) } \\
\text { ESW: Health Sector PER (FY05), Strategic } \\
\text { Country Gender Assessment (FY04) }\end{array}$ \\
\hline
\end{tabular}




\begin{tabular}{|c|c|c|c|}
\hline Subject: HIV/AIDS & & $\begin{array}{l}\text { Behavior change } \\
\text { education; } \\
\text { prevention, care and } \\
\text { risk mitigation } \\
\text { services. }\end{array}$ & $\begin{array}{l}\text { Bank: } \\
\text { On-going Portfolio: ZANARA (FY03), } \\
\text { ZAMSIF (FY00), Aids Component } \\
\text { BESSIP(FY00) } \\
\text { New Lending: HIV/AIDS Corridor Project } \\
\text { (Sub-regional project) (FY07) } \\
\text { ESW: Social Safety Nets and Protection } \\
\text { Strategy Note (FY04), Strategic Country } \\
\text { Gender Assessment (FY04) }\end{array}$ \\
\hline \multicolumn{4}{|c|}{ Goal: Better educated populace, with relevant job skills as well as academic training } \\
\hline Subject: Education & & $\begin{array}{l}\text { Provision and quality } \\
\text { of primary education }\end{array}$ & $\begin{array}{l}\text { Bank: } \\
\text { On-going Portfolio: BESSIP I } \\
\text { (SWAP)(FY99), TEVET(FY01) } \\
\text { ZAMSIF (FY00) } \\
\text { New Lending: BESSIP II (FY06) (SWAP), } \\
\text { PRSC (education) FY06 (high case only) } \\
\text { ESW: Education Sector PER(FY05) }\end{array}$ \\
\hline \multicolumn{4}{|c|}{ Goal: Improved living conditions for poor/vulnerable households in drought prone areas } \\
\hline $\begin{array}{l}\text { Subject: Social } \\
\text { Protection/ Risk } \\
\text { Mitigation }\end{array}$ & & $\begin{array}{l}\text { Social protection and } \\
\text { risk management } \\
\text { systems }\end{array}$ & $\begin{array}{l}\text { IMF: SMP and PRGF } \\
\text { Bank: } \\
\frac{\text { Ongoing Portfolio: Emergency Drought }}{\text { Recovery Project }} \\
\text { New Lending: Health/Nutrition Project, } \\
\text { Agriculture Project, SEED } \\
\text { ESW: Poverty and Vulnerability Assessment, } \\
\text { Strategic Country Gender Assessment, Social } \\
\text { Safety Nets and Social Protection Strategy } \\
\text { Note, Health Sector Review }\end{array}$ \\
\hline \multicolumn{4}{|c|}{ Goal: Good governance and public sector management } \\
\hline $\begin{array}{l}\text { Subject: Public } \\
\text { Expenditure }\end{array}$ & $\begin{array}{l}\text { Medium-term } \\
\text { budget framework, } \\
\text { tax policy and } \\
\text { administration. } \\
\text { Arrears and } \\
\text { commitment } \\
\text { control }\end{array}$ & $\begin{array}{l}\text { Public expenditure } \\
\text { analysis, } \\
\text { Capacity building in } \\
\text { financial management } \\
\text { and accountability }\end{array}$ & $\begin{array}{l}\text { IMF: SMP and PRGF; measures to strengthen } \\
\text { the Office of the Auditor General; measures to } \\
\text { put in place the IFMIS; multiyear plan for } \\
\text { clearing the stock of arrears; and measures to } \\
\text { ensure timely reporting of government } \\
\text { accounts to Parliament as required by law. } \\
\text { Bank: } \\
\text { On-going Portfolio: PSCAP I } \\
\text { New Lending: PSCAP/PEMFAP II } \\
\text { ESW: PEMFAR (FY03) } \\
\text { Jointly: HIPC AAP expenditure tracking } \\
\text { assessment }\end{array}$ \\
\hline \multicolumn{4}{|c|}{ Goal: A productive and efficient public service } \\
\hline $\begin{array}{l}\text { Subject: Public } \\
\text { Sector Reform and } \\
\text { Restructuring }\end{array}$ & & $\begin{array}{l}\text { Pay reform, public } \\
\text { sector restructuring }\end{array}$ & $\begin{array}{l}\text { Bank: } \\
\text { On-going Portfolio: PSCAP I } \\
\text { New Lending: PSCAP/PEMFAP II, SAC } \\
\text { (FY05) } \\
\text { ESW: PEMFAR(FY03), Governance Survey }\end{array}$ \\
\hline
\end{tabular}

Questions may be referred to Jos Verbeek (202-473-5539). 


\section{Zambia: Statistical Issues}

\section{Zambia is a participant in the GDDS project for Anglophone African countries and has begun receiving technical assistance in statistics under the project. Zambia's GDDS metadata was first posted on the Dissemination Standards Bulletin Board in November 2002 and was last updated in February 2004.}

The present arrangements for the compilation of macroeconomic statistics involve duplication of effort and insufficient coordination among the Bank of Zambia (BoZ), the Ministry of Finance, and the Central Statistical Office (CSO). The situation largely reflects resource constraints and organizational weakness within the CSO that have affected its ability to produce economic statistics on a timely basis.

\section{Real sector}

An IMF/DFID GDDS mission visited Lusaka from June 24 to July 5, 2002 to provide technical assistance to the CSO on national accounts, focusing on improving the source data (surveys); introducing the phased implementation of the System of National Accounts 1993 (1993 SNA); and in developing quarterly GDP estimates. The mission's main findings are summarized below.

Since its inception, the CSO has been compiling and disseminating annual national accounts estimates, using both the production and expenditure approaches. The national accounts estimates are compiled according to the conceptual guidelines of the $1968 \mathrm{SNA}$, but a phased approach to the introduction of the 1993 SNA is planned. Currently, the estimates are released on the basis of a well-established schedule and cover, on the production side, 11 industry groups and 23 subgroups, and, on the expenditure side, the 6 main components, at both constant and current prices. For the production approach, 1994 is the latest benchmark year for value-added ratios. For many important industry areas, such as wholesale and retail trade, construction, business services and many other service industries consisting mainly of smallscale private service providers, there are no appropriate indicators. The data that are currently available are mostly quarterly volume or quantity indicators of production. These are used in the construction of quarterly indicators of GDP by industry at constant prices. Data that would permit the compilation of the more comprehensive annual levels, such as data on total production and intermediate consumption of establishments, are not available. On the expenditure side, there are no current indicators of household consumption, and private final consumption expenditure is derived residually. Source data to estimate gross fixed capital formation and changes in stocks are incomplete.

Current price estimates for both the production and the expenditure sides are derived from the constant price indicators by using wholesale price indices (WPIs) and consumer price indices (CPIs) as inflators. For the most recent period, the WPI was no longer available and the CPI components were used throughout the system. 
The coverage of basic source data for the national accounts estimates has been rapidly eroding in recent years, at the same time as major structural changes have occurred in the economy. This lack of adequate source data to support the national accounts has, increasingly, placed the quality of the GDP estimates in serious jeopardy. Moreover, even some major methodological improvements within national accounts, such as the adoption of the commodity flow approach to estimate some of the aggregates, have not been adopted. Further, the CSO has not used the results of the input-output table constructed for the period 1994-1999, to improve the estimation process. The authorities' plan to implement the economic census project for 2002 constitutes a major breakthrough in the development of source data for the national accounts.

A follow-up mission visited Lusaka during March 3-19, 2003. The mission noted that the short-term recommendations made during the first mission were not carried out due to lack of staff resources.

\section{Government finance}

Zambia's GFS data have not been updated since 2000. Last information available and published in the GFS Yearbook 2003 is preliminary for 1998 and forecast data for 1999. The coverage is limited to budgetary central government. No monthly or quarterly fiscal data are reported for publication in International Financial Statistics (IFS).

The authorities report monthly budget data for the Fund's operational use in a timely manner. However, data are often subject to substantial revisions later in the year. Local government fiscal data are not available.

\section{Monetary accounts}

There has been progress made in the compilation of monetary statistics, and the monetary survey is published on a monthly basis. The BoZ has also eliminated discrepancies between its own records of IMF accounts and data from the Finance Department of the IMF.

In April 2003, the Bank of Zambia fully switched to a new computing system for generating its monthly trial balance, which should enable it to produce its monetary accounts on a regular timely basis. A July 2003 STA monetary and financial statistics mission recommended the recording of deposits on a gross, rather than on a net, basis; the reporting of central government securities at cost, rather than at face value; and the reclassification of some accounts.

Data reported by commercial banks are adequate, but the other depository corporations survey should be expanded to cover also four nonbank deposit-taking institutions.

Furthermore, the Bank of Zambia should include in the survey the accounts of all the banks currently in the process of liquidation, classifying their deposits as restricted deposits excluded from broad money. 


\section{Balance of payments}

In May 2000, a STA mission found compilation of data on imports, exports, and foreign direct investment to be inadequate and made a number of recommendations to improve the coverage of the data. Since then, the authorities have prepared a work plan to implement the recommendations of the mission, and some improvements have been made in the coverage of the customs data and the methodology for compiling some balance of payments components. However, the quality of balance of payments data continues to be problematic, as data sources are poor and unreliable, while the methodology is inadequate.

There are no sufficient data sources on private sector or foreign assets and liabilities available to compile an international investment position statement. 
$-88-$

APPENDIX V

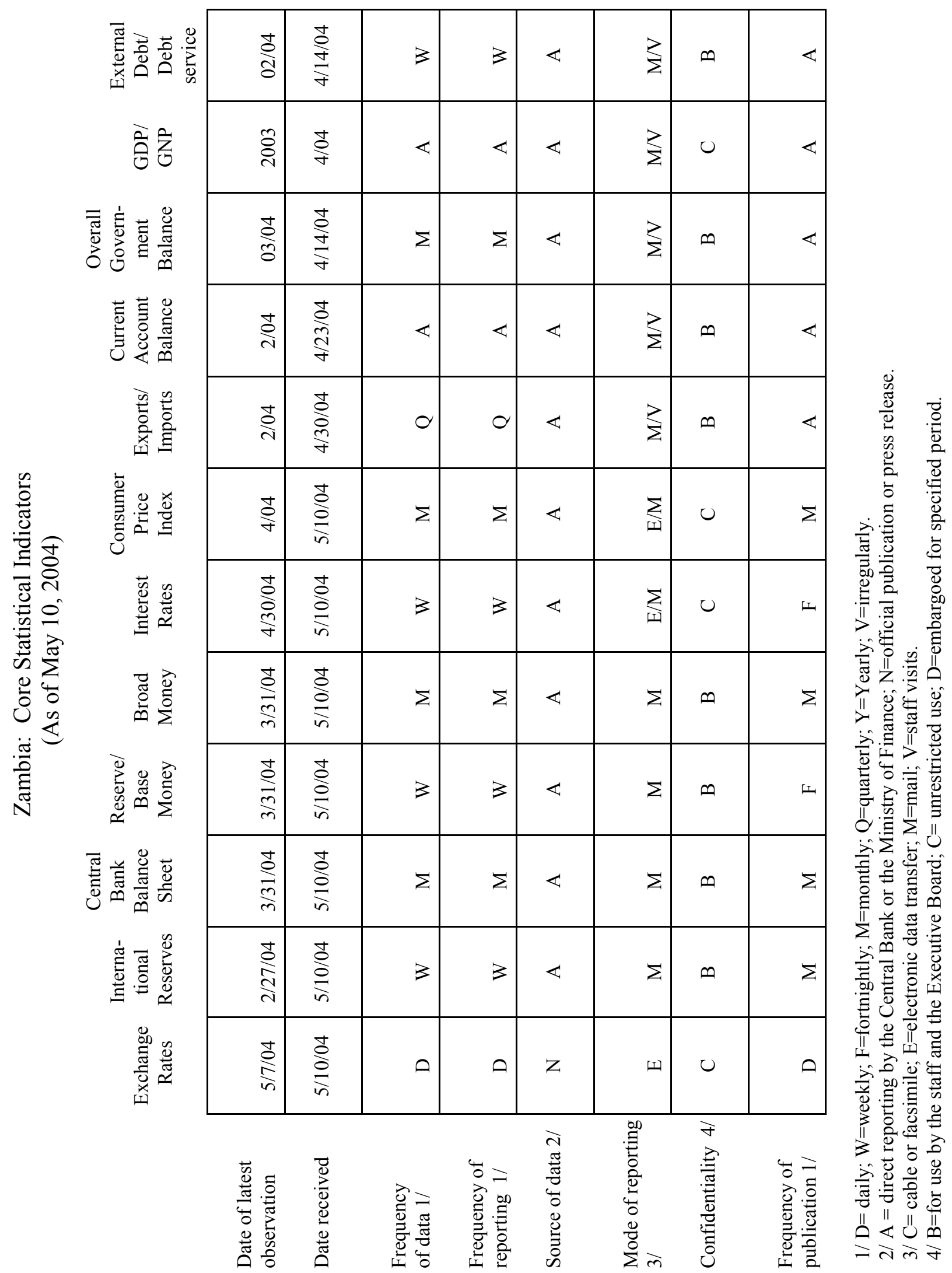




\section{Zambia: Social and Demographic Indicators}

Area (thousand sq. km.)

Poverty and inequality (1998)

Percent of national income

Highest 20 percent

Lowest 20 percent

Gini coefficient

Population below the poverty line (percent) Rural poverty (percent of rural population)

Labor force (1998)

Total participation rate (percent)

Percent employed in agriculture

Percent in manufacturing

Percent in mining

Education (2000)

Gross enrollment rates (percent)

Primary

Secondary

Tertiary

Illiteracy (percent of adult population, 2001)

Total

Men

Women
753 Population characteristics (2001)

Total population (in millions)

10.3

Annual rate of growth (percent)

Population density (per sq. km.)

Urban population

57 (percent of total)

3 Proportion in capital city

(percent of urban population)

0.53 Health (1998)

73 Life expectancy at birth (years)

37

83 Infant mortality (per 1,000 live births) 112

Mortality under 5 years (per 1,000) 202

Maternal mortality (per 1,000 live births) 650

62 Child immunization rate

70 (under 12 months; percent)

2 Child malnutrition (1997)

(under 5 years)

Percent underweight

Percent stunted

HIV/AIDS prevalence rate (percent)

Access to safe water (1998)

78

24 Percent of total population 43

2 Urban population 64

Rural population $\quad 27$

Sources: World Bank, World Development Indicators, 2003; and for employment data, Zambia Central Statistical Office, Living Conditions in Zambia, 1998. 


\section{Statement by the IMF Staff Representative June 14, 2004}

This statement provides additional information that has become available since the issuance of the staff report for Zambia. Developments through end-May were in line with the staff-monitored program (SMP) and, therefore, do not alter the thrust of the staff's assessment.

- In May, the 12-month rate of inflation stood at 17.4 percent, slightly below the SMP target (18.1 percent). The kwacha has remained stable against the U.S. dollar.

- $\quad$ Available data indicate that eight out of the nine quantitative targets for April and May were met. The target on the nonaccumulation of arrears on wages was missed by a small margin in April and, on the basis of partial data, appears to have also not been observed in May. The ceilings on net domestic assets and gross international reserves of the Bank of Zambia and net domestic financing of government were again met by large margins in April. Preliminary data indicate that that these ceilings were also met by large margins in May and they would also have been observed if wage arrears had not been incurred.

- $\quad$ Through May, government tax revenues were in line with the program, while nontax revenues (fees and penalties) were 0.2 percent of GDP less than programmed. Expenditures remained below the program targets, mainly because of a slow pace of execution of domestically financed capital spending in the first quarter of the year, a lower than anticipated monthly wage bill and savings on domestic interest payments. Funding for poverty-reducing programs was in line with the targets.

- $\quad$ Reserve money increased by 2.7 percent through May, well below the rate of 6.8 percent projected under the SMP. However, through end-April, broad money growth exceeded the target (8.5 percent compared with a target of 5.1 percent), reflecting an overperformance in net foreign assets of the banking system, as well as larger than expected credit to the private sector. The average commercial bank lending rate declined to 37.3 percent in May from 45.8 percent in October 2003. The Bank of Zambia has continued to take action to mop up excess liquidity in the banking system; average interest rates on treasury bills stabilized at just below 7 percent in May. Staff is closely monitoring developments in this area.

- $\quad$ On June 2, the authorities confirmed in writing that Cabinet had approved the Public Sector Management and Financial Accountability program and received, for consideration and approval, an action plan for implementing the Financial Sector Development Plan, thereby meeting the two prior actions for the approval of the new PRGF arrangement. All the continuous benchmarks under the SMP were observed. 
Press Release No. 04/117

FOR IMMEDIATE RELEASE

June 16, 2004
International Monetary Fund

Washington, D.C. 20431 USA

\section{IMF Approves US\$320.41 Million PRGF Arrangement for Zambia}

The Executive Board of the International Monetary Fund (IMF) has approved a three-year arrangement under the Poverty Reduction and Growth Facility (PRGF) for Zambia in an amount equivalent to SDR 220.095 million (about US\$320.41 million) to support the government's economic program into June 2007. The first disbursement of SDR 82.536 million (about US\$120.15 million) under the arrangement will become available immediately.

The PRGF is the IMF's concessional facility for low-income countries. It is intended that PRGF-supported programs are based on country-owned poverty reduction strategies adopted in a participatory process involving civil society and development partners and articulated in a Poverty Reduction Strategy Paper (PRSP). This is intended to ensure that PRGF-supported programs are consistent with a comprehensive framework for macroeconomic, structural, and social policies to foster growth and reduce poverty. PRGF loans carry an annual interest rate of 0.5 percent and are repayable over 10 years with a $5 \frac{1}{2}$-year grace period on principal payments.

Following the IMF Executive Board discussion on Zambia, Takatoshi Kato, Deputy Managing Director and Acting Chairman, stated:

"Zambia's performance continues to improve, with the economy now enjoying the strongest period of growth in the last two decades and the lowest rate of inflation in two decades. Nevertheless, the country's economy remains fragile and significant progress toward the Millennium Development Goals (MDGs) will require even faster economic growth and better targeted public spending. In this regard, prudent macroeconomic management and a deepening of structural reforms will be critical.

“The government's program for 2004, which will be supported by the Poverty Reduction and Growth Facility (PRGF), responds to the urgent need for fiscal consolidation to limit the recent increase in domestic debt and to redirect spending to priority areas. Under the program, non-priority expenditures, including on wages, will be contained and plans for rightsizing and pay reform of the civil service will be expedited to support the effective delivery of public services. Fiscal adjustment and a prudent monetary policy should help bring about a sustainable decline in domestic interest rates and prices. 
“The government's structural reform agenda focuses on improving public expenditure management and financial accountability; addressing the problems of the insolvent state-owned nonbank financial institutions; and completing the privatization of the Zambia National Commercial Bank. The government also intends to improve the environment for private sector activities by removing obstacles to investments.

“Zambia's first Poverty Reduction Strategy Paper (PRSP) Progress Report concludes that PRSP implementation was weaker than intended because of pressures on the budget. However, in light of the recent reforms and policy commitments, the strategy proposed in the PRSP continues to provide a sound basis for continued access to Fund concessional assistance. To pave the way for reaching the HIPC completion point, Zambia will need to satisfactorily implement the PRSP, complete a six month track record under the PRGF, and attain the few remaining HIPC triggers," Mr. Kato said. 


\begin{abstract}
ANNEX
Recent Economic Developments

Zambia's growth performance has continued to strengthen and reached 5.1 percent in 2003, marking the fourth consecutive year of economic expansion and the longest period of sustained growth in more than two decades. At the same time, inflation declined to 17 percent at the end of 2003, the lowest level in over 20 years.

These favorable outcomes for growth and inflation in 2003 were, however, aided by exogenous developments that helped to offset the impact of serious slippages. Large unbudgeted expenditures related to security, payment of benefits and wage arrears to workers in the mining sector, and shortfalls in external assistance resulted in domestic borrowing in 2003 equivalent to 5 percent of GDP, compared to the 2 percent in 2002. At the same time, spending on poverty- reduction programs fell short of the budgeted levels.

The authorities' budget for 2004 is geared to averting a further upward spiral in domestic debt and interest costs. In the first three months of 2004, fiscal performance improved significantly. Revenues through end-March were in line with targets established under the extended Staff Monitored Program (SMP). The ceiling on domestic financing was met by a comfortable margin, and all expenditure categories were at or below their programmed levels.
\end{abstract}

\title{
Program Summary
}

The centerpiece of the policy framework is a strong, front-loaded fiscal adjustment to halt the unsustainable cycle of rising domestic debt and interest payments, and increase spending on poverty-reducing programs. The program aims to increase real growth GDP to at least 5 percent per annum over the medium term. In combination with a reorientation in expenditures attained through structural reforms, this would allow an increase in spending on priority poverty-reducing programs to 3.7 percent in 2007 from 1 percent of GDP in 2003.

The structural reform agenda covers four main areas that support the objectives of the PRSP and were identified as priorities: reforms in public expenditure management and restructuring of the public sector will support fiscal consolidation and a reorientation of spending towards poverty reduction; financial sector reforms will support improvement in the efficiency and scope of financial intermediation; private sector development will be fostered by completion of the privatization program and a removal of obstacles to private sector growth; and there will be continued improvement in governance and in transparency of government operations.

The macroeconomic framework does not assume sharply higher assistance over the medium term, although sustained high levels of external assistance needed to support faster growth are likely to be forthcoming as policy implementation continues to improve.

Macroeconomic objectives for 2004 include real GDP growth of about 3.5 percent, an inflation rate of no more than 20 percent, and a build-up of gross international reserves to about one 
month of import cover by end-2004. The government has reiterated its intention to hold the wage bill to no more than 8 percent of GDP in 2004. The monetary program aims at limiting broad money growth to 18 percent in 2004 to preserve the gains in reducing inflation in the face of less favorable trends in fuel prices.

Zambia became a member of the IMF on September 23, 1965. Its quota is SDR 489.10 million (about US\$712 million, and its outstanding use of Fund resources currently totals SDR 576.89 million (about US\$839.83 million). 
Table 1. Zambia: Selected Economic and Financial Indicators, 2002-2007

\begin{tabular}{|c|c|c|c|c|c|c|}
\hline & 2002 & 2003 & 2004 & 2005 & 2006 & 2007 \\
\hline & Est. & Est. & Prog. & Proj. & Proj. & Proj. \\
\hline & \multicolumn{6}{|c|}{ (Annual percentage change, unless otherwise indicated) } \\
\hline \multicolumn{7}{|l|}{ National income and prices } \\
\hline Real GDP & 3.3 & 5.1 & 3.5 & 4.5 & 5.0 & 5.0 \\
\hline GDP deflator & 19.9 & 20.1 & 20.4 & 13.9 & 10.5 & 6.0 \\
\hline Consumer prices (annual average) & 22.2 & 21.5 & 18.5 & 17.4 & 12.6 & 7.6 \\
\hline Consumer prices (end of period) & 26.7 & 17.2 & 20.0 & 15.0 & 10.0 & 5.0 \\
\hline \multicolumn{7}{|l|}{ External sector } \\
\hline U.S. dollar value of exports of goods and services & 2.4 & 23.4 & 21.5 & 12.6 & 8.4 & 1.4 \\
\hline U.S. dollar value of imports of goods and services & -2.5 & 13.3 & 13.7 & 10.9 & 5.6 & 2.7 \\
\hline Export volume & 11.1 & 9.4 & 4.9 & 16.8 & 12.0 & 0.9 \\
\hline Import volume & -4.3 & 7.4 & 7.7 & 15.3 & 9.8 & 2.5 \\
\hline Copper export volume & 11.3 & 7.1 & 8.0 & 22.9 & 14.8 & 4.5 \\
\hline Copper export prices (average, U.S. dollars per pound) & 0.70 & 0.78 & 0.96 & 0.92 & 0.88 & 0.86 \\
\hline Nominal effective exchange rate (annual average) $1 /$ & -19.3 & -14.5 & -13.5 & $\ldots$ & $\ldots$ & $\ldots$ \\
\hline Real effective exchange rate (annual average) $1 /$ & -5.8 & -0.8 & -0.2 & $\ldots$ & $\ldots$ & $\ldots$ \\
\hline Terms of trade & -7.0 & 5.0 & 10.7 & -0.2 & 0.7 & -0.1 \\
\hline \multicolumn{7}{|l|}{ Money and credit (change in percent of beginning-of-year M2) } \\
\hline Net foreign assets & 68.5 & -9.0 & 0.0 & $\ldots$ & $\ldots$ & $\ldots$ \\
\hline Net domestic assets & -37.0 & 32.5 & 18.1 & $\ldots$ & $\ldots$ & $\ldots$ \\
\hline Net domestic credit & -29.4 & 36.6 & 18.8 & $\ldots$ & $\ldots$ & $\ldots$ \\
\hline Net claims on government & 3.1 & 27.0 & 9.7 & $\ldots$ & $\ldots$ & $\ldots$ \\
\hline Claims on nongovernment & 6.1 & 9.6 & 9.1 & $\ldots$ & $\ldots$ & $\ldots$ \\
\hline Broad money & 31.5 & 23.4 & 18.1 & $\ldots$ & $\ldots$ & $\ldots$ \\
\hline \multicolumn{7}{|l|}{ Central government budget } \\
\hline Revenue (excluding grants) & 16.0 & 26.5 & 30.0 & 18.3 & 16.3 & 11.3 \\
\hline Grants & 79.0 & 5.5 & -2.5 & 44.1 & 21.2 & 12.8 \\
\hline Expenditures 2/ & 22.8 & 22.5 & 10.2 & 23.8 & 14.2 & 11.4 \\
\hline \multirow[t]{2}{*}{ Domestic expenditures $2 / 3$ / } & 14.1 & 23.9 & 17.5 & 24.1 & 13.6 & 11.0 \\
\hline & \multicolumn{6}{|c|}{ (In percent of GDP) } \\
\hline \multicolumn{7}{|l|}{ Investment and savings } \\
\hline Gross national savings 4/ & 16.5 & 20.6 & 18.6 & 16.9 & 16.6 & 15.4 \\
\hline Gross foreign savings $5 /$ & 6.5 & 5.6 & 4.6 & 3.9 & 3.7 & 3.8 \\
\hline Gross domestic investment & 23.0 & 26.2 & 23.3 & 20.8 & 20.3 & 19.2 \\
\hline Of which: public investment & 11.8 & 11.5 & 9.2 & 10.0 & 10.5 & 11.5 \\
\hline \multicolumn{7}{|l|}{ Central government budget } \\
\hline Revenue and grants & 26.2 & 25.1 & 24.1 & 25.2 & 25.5 & 25.6 \\
\hline Revenue (excluding grants) & 17.9 & 18.1 & 18.7 & 18.6 & 18.6 & 18.6 \\
\hline Expenditures (excluding interest) $2 /$ & 27.8 & 27.3 & 23.1 & 24.5 & 24.8 & 25.4 \\
\hline Interest due 4/ & 4.1 & 3.9 & 4.2 & 3.9 & 3.1 & 2.6 \\
\hline Domestic expenditures 2/3/ & 21.3 & 21.0 & 19.7 & 20.5 & 20.1 & 20.0 \\
\hline Overall balance, cash basis & -6.3 & -6.6 & -3.4 & -3.2 & -2.4 & -2.4 \\
\hline Domestic balance, cash basis 5/ & -4.1 & -3.5 & -1.0 & -1.9 & -1.4 & -1.4 \\
\hline \multicolumn{7}{|l|}{ External sector } \\
\hline Current account balance, excl. grants & -17.3 & -14.3 & -11.4 & -11.6 & -11.5 & -11.9 \\
\hline Current account balance, incl. grants \& debt relief 6/ & -6.5 & -5.6 & -4.6 & -3.9 & -3.7 & -3.8 \\
\hline
\end{tabular}


Table 1. Zambia: Selected Economic and Financial Indicators, 2002-2007/Continued

\begin{tabular}{|c|c|c|c|c|c|c|}
\hline & $\begin{array}{r}2002 \\
\text { Est. }\end{array}$ & $\begin{array}{r}2003 \\
\text { Est. }\end{array}$ & $\begin{array}{l}2004 \\
\text { Prog. }\end{array}$ & $\begin{array}{l}2005 \\
\text { Proj. }\end{array}$ & $\begin{array}{l}2006 \\
\text { Proj. }\end{array}$ & $\begin{array}{l}2007 \\
\text { Proj. }\end{array}$ \\
\hline & \multicolumn{6}{|c|}{ (In percent of exports of goods and services) } \\
\hline \multicolumn{7}{|l|}{ External debt } \\
\hline External official debt service & 11.4 & 14.1 & 23.4 & 5.5 & 4.4 & 5.5 \\
\hline External program assistance $7 /$ & 12.8 & 4.1 & 4.3 & 4.3 & 2.9 & 2.8 \\
\hline \multicolumn{7}{|c|}{ (In millions of U.S. dollars, unless otherwise indicated) } \\
\hline Current account balance, incl. grants and debt relief $6 /$ & -246 & -241 & -238 & -207 & -212 & -232 \\
\hline Overall balance of payments & -383 & -321 & -283 & -216 & -225 & -205 \\
\hline Gross official reserves (end of period) & 283 & 197 & 173 & 277 & 334 & 392 \\
\hline In months of imports of goods and services & 2.2 & 1.3 & 1.0 & 1.5 & 1.7 & 1.9 \\
\hline
\end{tabular}

Sources: Zambian authorities; and IMF Staff estimates and projections.

1/ For 2004, figures represent 12-month average to January.

$2 /$ Including contingency reserve and payments of domestic arrears.

3/ Excludes external interest payments and foreign-financed capital expenditure.

4/ After enhanced HIPC Initiative debt relief.

6/ Includes program and budget grants and debt relief on interest payments.

7/ For 2005-07, figures are preliminary projections and only includes identified commitments. 


\section{Statement by Ismaila Usman, Executive Director for Zambia June 14, 2004}

1. At the time of the Article IV consultation discussion last April, the Board had the opportunity to appreciate the continued improvement in Zambia's economic performance and also the authorities' resolve to continue to strengthen macroeconomic stability and step up structural reforms, to sustain higher economic growth and to reduce the prevailing high poverty. Important steps in this regard, were the undertaking of determined efforts to address the weaknesses in policy implementation faced in the recent past and marshalling wider political support to buttress the ownership of the reform program. This is reflected in the satisfactory manner in which the Staff Monitored Program (SMP) was implemented as manifested by the observance, some of them by large margins, of most of the performance criteria and structural benchmarks through April-2004, as well as in complying with the prior actions for the new PRGF program.

2. During 2003, the economy continued to expand at positive rates and inflation has been brought down to 17 percent, the lowest level in over two decades. Notwithstanding these favorable outcomes, my authorities are firmly committed to persevere with prudent policies, essential for addressing the economy's remaining vulnerabilities. Hence, they have embarked on an ambitious reform agenda to be implemented in the context of a medium-term adjustment strategy for the period 2004-07, aimed mainly at further enhancing the efficiency of government operations, promoting an enabling environment for private sector development and strengthening governance. In line with the objectives established in the PRSP, this strategy will remain focused on accelerating economic growth through improvements in total factor productivity and most importantly, by means of further diversification efforts that could result in new employment opportunities and reduction in poverty.

3. The government's medium-term reform strategy envisages the attainment of a real GDP growth of at least 5 percent per annum, the reduction of the inflation rate to single digits by the terminal year of the program period, and the strengthening of the international reserves position. In pursuit of these goals, the strategy will maintain its focus on three main pillars: (1) diversification of the sources of growth; (2) strengthening of fiscal position; and (3) supporting private sector development. The government is also committed to improve governance and transparency, to promote an enabling investment climate.

4. Despite the encouraging growth performance during the past several years, the authorities recognize that the projected annual growth rate of 5 percent over the mediumterm is not enough to meet the Millennium Development Goals (MDGs) targets. They are therefore, by improving the provision of basic services and establishing an investment climate that is conducive for greater private sector participation, expecting to move the economy towards a higher growth path, The authorities are confident that the launching of the Private Sector Development Initiative (PSDI) that is being prepared through a process of consultation with key stakeholders, will contribute to improve the environment for private sector growth and accelerate domestic and foreign investment. Moreover, since the majority 
of the poor population is concentrated in the rural areas, priority attention will be accorded to supporting agricultural development and the expansion of basic infrastructures to facilitate growth. This has not been given adequate attention in the previous programs as documented in the ex-post assessment paper, discussed last April.

5. My Zambian authorities look forward to the Board's favorable consideration of their request for new three-year PRGF arrangement, which will be not only provide direct financial assistance in the implementation of Zambia's medium-term reform strategy but also lend additional credence to the authorities' program that could trigger support from the donor community.

\section{Fiscal Policy}

6. Since fiscal consolidation remains central to the government's medium-term reform strategy, the Zambian authorities have reaffirmed their commitment to correct the fiscal slippages which occurred last year, by the bold steps they have taken during the implementation of the SMP in the first half of 2004. The fact that the fiscal adjustment effort will be front-loaded, while allowing for increase in poverty-related spending, is a further demonstration of their determination to preserve and consolidate these gains. This decision was undertaken in the belief that it would be necessary to break the cycle of rising domestic debt and interest payments that have beset their fiscal performance recently, thus contributing to preserving macroeconomic stability. As a result of this approach, the overall fiscal deficit is expected to decline substantially from 6.6 percent of GDP in 2003 to 3.4 percent in the current year, with further reductions envisaged beyond 2004. Although revenue is expected to increase by 0.6 percentage points of GDP in 2004, mainly as a result of the broadening of the tax base, the fiscal adjustment will rely essentially on expenditure containment. In particular, it is anticipated that the wage bill will be strictly restricted to less than 8 percent of GDP and there will be no general wage increase in 2004. Significant savings are also expected to occur from the ongoing re-organization of operations, substantive cuts in discretionary spending, especially under recurrent departmental charges, and particularly, from the rigorous enforcement of the commitment control system (CCS) that will improve the budget execution system. The authorities remain firm on their commitment to avoid unbudgeted spending.

7. In addition to these measures, the authorities believe that a comprehensive reform of the public sector is required to produce a lasting effect on the improvement of the efficiency of government operations. To this end, they intend to commence the implementation of the Public Expenditure Management and Financial Accountability (PEMFA) program in 2004, for a more effective management of public resources and enhanced accountability. The authorities are also in the process of developing a plan, with the assistance of the World Bank, to streamline the civil service and restructure the pay system. These measures will enable increased spending on priority poverty-reducing programs to facilitate progress towards achieving the MDGs targets. The government reaffirms its policy of zero tolerance for corruption. As part of the effort underway to improve transparency, the government will be publishing the quarterly reports of budget execution and is taking steps for enhancing the independence of the Office of the Auditor General. 


\section{Monetary and Exchange Rate Policies}

8. The authorities will maintain prudent monetary and exchange rate policies to achieve the projected program targets for inflation and international reserves. The planned reduction in fiscal reliance on bank borrowing will provide room for a significant increase in credit to the economy. The authorities recognize that interest rates on Government securities declined rapidly as a result of the reduction in reserve requirements in October 2003. They reiterate that the easing of the monetary policy was well received by the business community and, most importantly, has achieved the intended objective of increasing credit to the private sector. They are, however, aware of the potential risks that a rapid decline in interest rates may pose to other macroeconomic variables, such as inflation and exchange rate. Therefore, the central bank will continue to monitor closely monetary developments and take necessary actions to ensure that credit and broad money are kept within the limits envisaged in the program. Consistent with this, and taking into account the domestic financing requirements, adjustments are being made to the tender sizes for government securities, effective June 7 , 2004. The exchange rate will continue to reflect market conditions with the central bank limiting its intervention in the market only to smooth out short-term fluctuations.

9. The authorities are also moving forward in taking the necessary measures for addressing the weaknesses identified in the Financial Sector Assessment Program. In this regard, they are in the process of finalizing the Financial Sector Development Plan (FSDP), which seeks to deal with these problems, in particular, the need to accord greater autonomy in the formulation of monetary policy, the strengthening of the authority of the central bank, and resolving the problem of insolvent state-owned nonbank financial institutions (NBFIs). The authorities also view the development of the regulatory framework for microfinance institutions as an urgent step to support the small and medium-scale projects, which have a critical role to play in promoting growth and creating job opportunities.

\section{External Sector}

10. Zambia's external current account position is projected to improve somewhat on account of higher copper prices and increase in nontraditional exports. The country's trade regime remains open and supportive of export development and economic diversification.

11. A major problem for the authorities has, however, been the large external debt overhang, which they view as a serious impediment to boosting investment and growth and to reducing poverty. In this regard, they made significant progress in meeting most of the triggers for the HIPC completion point. They are, however, not only greatly disappointed but also highly concerned with the delay for the consideration of their HIPC completion point, brought about by the proposed postponement to early 2005 , based on the need for a minimum of six months track record of good performance under the PRGF arrangement. They request that since the strength of the reform measures implemented under the SMP since January 2004 is the same as of those described under the PRGF arrangement, this should be taken into account in the evaluation of the country's track record of sound economic management. A period of assessment from January to, say, October 2004 should provide adequate extended period for evaluation to enable Zambia to attain the completion point by December 
2004, as initially envisaged. Even maintaining the start date for the PRGF arrangement on May 1, 2004 as initially agreed with the authorities, would still enable Zambia to reach the completion point by end-2004, provided that the six-months track record to October 2004, remains satisfactory. The authorities are therefore, strongly appealing to the Board to consider favorably their request to maintain the start date for the program on May 1, 2004.

12. For the authorities, any delay beyond December 2004, would carry the great risk of jeopardizing the credibility of the government and more importantly eroding public support for the reform program. Another serious consequence of such a postponement would be to prevent the allocation to poverty-related spending, of the additional resources that would accrue from the HIPC debt relief, thus making it even more difficult to meet the MDGs, than is the case presently.

\section{Conclusion}

13. Lastly, I would like to convey my Zambian authorities' gratitude for the Fund's continued support, in helping the country face its many complex challenges. 